\title{
Hydrogel biomaterials in focus : new polymeric biomaterials and their possible utility in ophthalmology
}

Citation for published version (APA):

Bruining, M. J. (2001). Hydrogel biomaterials in focus : new polymeric biomaterials and their possible utility in ophthalmology. [Doctoral Thesis, Maastricht University]. Datawyse / Universitaire Pers Maastricht. https://doi.org/10.26481/dis.20011031mb

Document status and date:

Published: 01/01/2001

DOI:

10.26481/dis.20011031mb

Document Version:

Publisher's PDF, also known as Version of record

Please check the document version of this publication:

- A submitted manuscript is the version of the article upon submission and before peer-review. There can be important differences between the submitted version and the official published version of record.

People interested in the research are advised to contact the author for the final version of the publication, or visit the DOI to the publisher's website.

- The final author version and the galley proof are versions of the publication after peer review.

- The final published version features the final layout of the paper including the volume, issue and page numbers.

Link to publication

\footnotetext{
General rights rights.

- You may freely distribute the URL identifying the publication in the public portal. please follow below link for the End User Agreement:

www.umlib.nl/taverne-license

Take down policy

If you believe that this document breaches copyright please contact us at:

repository@maastrichtuniversity.nl

providing details and we will investigate your claim.
}

Copyright and moral rights for the publications made accessible in the public portal are retained by the authors and/or other copyright owners and it is a condition of accessing publications that users recognise and abide by the legal requirements associated with these

- Users may download and print one copy of any publication from the public portal for the purpose of private study or research.

- You may not further distribute the material or use it for any profit-making activity or commercial gain

If the publication is distributed under the terms of Article $25 \mathrm{fa}$ of the Dutch Copyright Act, indicated by the "Taverne" license above, 


\section{Hydrogel Biomaterials in Focus}

New Polymeric Biomaterials and

their Possible Utility in Ophthalmology 
Druk: Datawyse, Universitaire Pers Maastricht

ISBN 90-9015159-1

(C) 2001, M. J. Bruining

No part of this publication may be reproduced or transmitted in any form or by any means, electronic or mechanical, including photocopy, recording, or any information storage and retrieval systems, without permission from the copyright owner. 


\title{
Hydrogel Biomaterials in Focus
}

\author{
New Polymeric Biomaterials and \\ their Possible Utility in Ophthalmology
}

PROEFSCHRIFT

ter verkrijging van de graad van doctor aan de Universiteit Maastricht, op gezag van de Rector Magnificus, prof. dr. A. C. Nieuwenhuijzen Kruseman, volgens het besluit van het College van Decanen, in het openbaar te verdedigen op woensdag 31 oktober 2001 om 14.00 uur

door

Monique Jeanet Bruining

geboren te Rotterdam 
Promotoren:

prof. dr. ir. L. H. Koole

prof. dr. F. H. Hendrikse

Beoordelingscommissie: prof. dr. R. Geesink (voorzitter)

prof. dr. J. de Mey

prof. dr. H. C. J. Ottenheijm

prof. dr. J. Rosing

Het verschijnen van dit proefschrift werd mede mogelijk gemaakt door steun van de Nederlandse Vereniging voor Biomaterialen. 
Voor mijn ouders

Aan Marwijn 



\section{Table of Contents}

\section{Chapter 1 Introduction}

1.1 Biomaterials in focus 2

1.2 Hydrogels 3

1.2.1 Concepts of biodegradable hydrogels 5

$\begin{array}{lll}\text { 1.2.2 Hydrogels in drug delivery formulations } & 7\end{array}$

$\begin{array}{lll}1.3 & \text { Hydrogels in ophthalmology } & 7\end{array}$

1.3.1 Anatomy of the eye 8

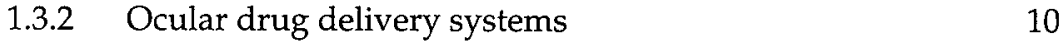

$\begin{array}{ll}\text { 1.3.3 Hydrogels as corneal implants } & 11\end{array}$

1.4 Biocompatibility and cytotoxicity of hydrogels 12

1.5 Aim and outline of this thesis 13

$\begin{array}{lll}1.6 & \text { References } & 15\end{array}$

Chapter 2 New Biodegradable Networks of Poly(1-vinyl-2pyrrolidinone), Designed for Controlled Non-Burst Degradation in the Vitreous Body

Summary $\quad 20$

2.1 Introduction 21

2.2 Experimental section 23

$\begin{array}{lll}2.2 .1 & \text { Materials } & 23\end{array}$

$\begin{array}{ll}2.2 .2 \text { Methods } & 26\end{array}$

2.3 Results 30

2.3.1 Physico-chemical characterization of materials A-G 30

$\begin{array}{ll}\text { 2.3.2 Swelling and degradation in vitro } & 31\end{array}$

2.3.3 In vivo behavior of materials $\mathrm{A}-\mathrm{G}$ in the vitreous body
of a rabbit eye

2.4 Discussion 37

2.5 Concluding remarks 39

2.6 References 39

Chapter 3 Biodegradable Three-Dimensional Networks of Poly(dimethylaminoethyl methacrylate). Synthesis, Characterization and In vitro Studies of Structural Degradation and Cytotoxicity

$\begin{array}{ll}\text { Summary } & 42\end{array}$

3.1 Introduction 43

3.2 Experimental section $\quad 45$

$\begin{array}{lll}3.2 .1 \quad \text { Materials } & 45\end{array}$

3.2.2 Physico-chemical analysis of the polymeric materials 46

3.2.3 Cytotoxicity and biocompatibility of the polymeric
materials

3.3 Results and discussion $\quad 50$

3.3.1 Physico-chemical analysis $\quad 50$ 
3.3.2 Cytotoxicity and biocompatibility of the polymeric materials

$\begin{array}{lll}3.4 & \text { Concluding remarks } & 61\end{array}$

3.5 References

Chapter 4 NMR Microimaging as a Versatile Tool for Studying Water Uptake and Decomposition of Hydrophilic and Degradable Biomaterials

Summary

64

4.1 Introduction 64

4.2 Experimental section 66

4.2.1 Materials 66

$\begin{array}{ll}\text { 4.2.2 Methods } & 67\end{array}$

4.3 Results and discussion $\quad 69$

4.3.1 Polymeric materials based on crosslinked NVP 69

4.3.2 Water uptake and decomposition behavior of the hydrogels $\quad 69$

$\begin{array}{lll}4.4 & \text { Concluding remarks } & 71\end{array}$

$\begin{array}{lll}4.5 & \text { References } & 72\end{array}$

Chapter 5 Studies on New Polymeric Biomaterials with Tunable Hydrophilicity, and their Possible Utility in Corneal Repair Surgery

Summary 74

$\begin{array}{lll}5.1 & \text { Introduction } & 75\end{array}$

5.2 Experimental section $\quad 77$

5.2.1 Materials 77

$\begin{array}{ll}\text { 5.2.2 Physico-chemical analysis } & 79\end{array}$

5.2.3 Evaluation of protein adsorption onto polymeric materials 83

5.2.4 Evaluation of the biocompatibility 85

5.3 Results and discussion 86

5.3.1 Preparation and physico-chemical analysis of materials $\mathrm{A}-\mathrm{D}$

5.3.2 Cytotoxicity and biocompatibility of the polymeric materials 94

5.3.3 Adsorption of lysozyme onto the polymeric surfaces 97

5.4 Concluding remarks 100

$\begin{array}{lll}5.5 & \text { References } & 101\end{array}$

Epilogue 103

$\begin{array}{ll}\text { Summary } & 105\end{array}$

$\begin{array}{ll}\text { Samenvatting } & 109\end{array}$

Curriculum Vitae 113

List of publications $\quad 115$

$\begin{array}{ll}\text { Dankwoord } & 117\end{array}$ 


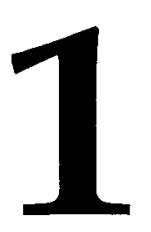

\section{Introduction}




\subsection{Biomaterials in focus}

Synthetic biomaterials are widely used in medicine, either for improving the quality of life of the patient, or to cope with immediately life-threatening conditions. ${ }^{1.5}$ Many medical devices, which are constructed from biomaterials, are implanted by surgeons every year. A patient with seriously impaired vision due to cataract can get a new plastic lens implanted, which restores sight within one day. ${ }^{6,7}$ A diseased heart valve can be replaced by a prosthesis that is essentially a construction made of metallic and polymeric biomaterials. ${ }^{89}$ A metallic implant can be used to replace the hip joint of an arthritic person, which has a rapid and dramatic impact on the patient's mobility. ${ }^{10-12} \mathrm{~A}$ cochlear prosthesis may restore some hearing to a person who has been totally deaf for years. ${ }^{13 \cdot 16}$ A metallic stent with a pharmacologically active coating can maintain blood flow in the coronary arteries of a patient with heart disease. ${ }^{1720}$ This list of examples could be continued for pages. Medical devices work: they do save lives and restore function.

Not all biomaterials and medical devices, however, completely satisfy the patient and the physician. In many cases, this is due to the fact that the biomaterial was not specifically designed and developed for its medical application. Surgeons have often experimented with "off the shelf" polymeric materials and metals to solve an acute problem. ${ }^{21}$ In some cases, this approach was successful, and the specific application of the material has become the golden standard.

An example is the use of poly(methyl methacrylate) (poly(MMA)) bone cement for the fixation of metallic orthopedic implants to the skeleton. ${ }^{22.23}$ This material was originally developed for the manufacture of denture bases. By coincidence, in the early $1960^{\prime}$ s, it was also used for the femural fixation of a metallic hip prosthesis. ${ }^{24}$ Forty years later, the use of poly(MMA) is still routine for cemented hip replacement, an operation which is performed more than one million times per year. Other medical devices, however, frequently perform less successfully. This is, in many cases, due to the fact that the body responds to the foreign material by walling it off in a thin, fibrous capsule. ${ }^{25}$ The biomaterial then becomes isolated without any functional connection between the device and its biological 
environment. Such an inert implant frequently leads to non-optimal performance and discomfort.

In contemporary biomaterials science, there is a clear trend to design new biomaterials such that they will become engaged in a positive interaction with their environment. Ideally, the biomaterial stimulates the normal healing processes of the body, which has the capacity to restore complex wound sites, or even to regrow blood vessels and parts of organs. It is clear that polymeric biomaterials are especially promising in this respect. Based on new insights in (patho)physiology and materials science, it is possible to create new functional biomaterials that are recognized by the body, cleanly turn on normal healing and perform similarly to the tissue that they replace. For soft tissue replacement, hydrogel biomaterials are especially promising, since accurate control over chemical, physical and biological properties can be achieved. ${ }^{26-29}$ Furthermore, hydrogels can be used as carriers for controlled local release of drugs. This thesis describes investigations on such novel hydrogel biomaterials. They were specifically designed for use in ophthalmic surgery, either as temporary depots for drugs, which have to be administered in the vitreous body of the eye, or for the replacement of corneal tissue. ${ }^{30-32}$

\subsection{Hydrogels}

Hydrogels are a class of specialty homo or co-polymers, which are mainly chemically or physically crosslinked networks based on hydrophilic monomers. ${ }^{26-40}$ They find numerous applications, particularly in the medical and pharmaceutical sectors. Features as programmability and controllability of e.g. swelling and decomposition make them ultimately suitable in a range of diverse applications. They are applied as soft contact lenses, membranes for biosensors, linings for artificial hearts, materials for artificial skin and in drug delivery systems. Materials as e.g. poly(vinyl alcohol), copolymers of lactic acid and glycolic acid, crosslinked poly(1-vinyl-2-pyrrolidinone) (poly(NVP)), poly(2-hydroxyethyl methacrylate) (poly(HEMA)) and clear polyurethane hydrogels are frequently and widely 
applied $^{2,+1-15}$ These materials have the capacity to imbibe large amounts of water (biological fluids) and as a consequence swelling of the materials is accomplished. The swelling behavior of these materials is affected by various factors such as: (i), the chemical structure, i.e. the hydrophilic and hydrophobic building blocks of the copolymer; (ii), the degree of crosslinking; (iii), the degree of porosity; (iv), the environment in the case of environmentally-sensitive hydrogels (specific stimuli as temperature, ionic strength and $\mathrm{pH}$ ).

Note that highly crosslinked materials exhibit less water uptake (swelling) than scarcely crosslinked systems. Crosslinking greatly hinders the mobility of the polymeric chain, hence lowering the swelling ratio.

Hydrogels owe their popularity to the fact that they resemble natural living tissue more than any other class of synthetic biomaterials. Their high water content and soft consistency is similar to natural tissue and therefore their application results in good compatibility with living cells and bodily fluids. Shalaby et al. showed that hydration of the polymeric system indeed plays an important role in the acceptance by the body. ${ }^{46}$ They studied drug delivery matrices of poly(NVP) hydrogels, which were administered in dry and in fully swollen state. The fully swollen hydrogel was retained for more than $24 \mathrm{~h}$ and up to $60 \mathrm{~h}$, whereas the dried material was emptied from the stomach in less than an hour.

These hydrogels are used in pharmaceutical formulations as e.g., drug delivery systems. Bettini et al. described the role played by polymer swelling in drug transport. The rate and the amount of drug delivery did not only depend on drug dissolution and diffusion through the matrix, but the solid drug translocation was also of considerable importance. ${ }^{47}$ Many groups have studied the utility of (co)polymers of lactic acid and glycolic acid for the controlled local release of drugs, growth factors, etc. For instance, Lu et al. showed that blends of poly(lactic-coglycolic acid) and poly(ethylene glycol) microparticles were suitable as delivery vehicle for controlled release of growth factors. ${ }^{48}$ More references on this subject are provided herein. 


\subsubsection{Concepts of biodegradable hydrogels}

Polymeric biomaterials can degrade via various routes. In this thesis emphasis will be placed on degradation via chemical hydrolysis. ${ }^{49.50}$ Chemical degradation occurs due to hydrolysis of hydrolyzable bonds of the polymeric system. Examples of hydrolyzable bonds are: amide-bonds, ester-bonds, carbonate-bonds, anhydrides, urethanes, and acetals. Chemical degradation depends on various factors as: the kind of hydrolyzable group, the environment, the crystallinity, the hydrophilicity, the crosslink density, the porosity, the composition and the molecular weights of the degradable material.

On a molecular level hydrolysis can take place via distinct routes or via combinations of these routes. Scheme 1.1 outlines these routes A - C.

Route A: hydrolysis of water-insoluble hydrogels with hydrolytically unstable crosslinks that yields water-soluble polymers: crosslinked gelatin, collagen, polyacrylamides, poly(vinyl alcohol), and poly(NVP) can undergo this type of degradation.

Route B: hydrolysis of water-insoluble linear polymers that become solubilized by hydrolysis, ionization, or protonation of a pendant group; poly(vinyl methyl ether/maleic anhydride) is a good example of this type of degradation. Dissolution is achieved by the degree of ionization of the carboxylic acid groups.

Route C: hydrolysis by backbone cleavage of water-insoluble polymers to small water-soluble molecules. Poly(lactic-co-glycolic acid), poly- $\varepsilon$-caprolactone and polyanhydrides formulations are well-known examples of this type of degradation. 
A
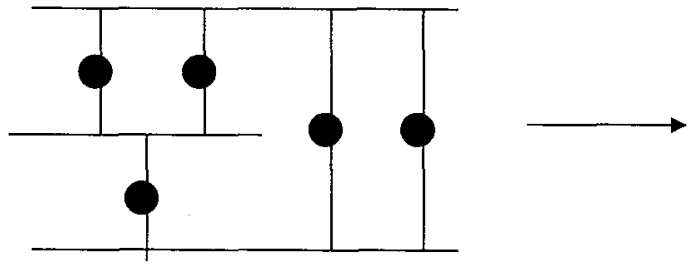

B
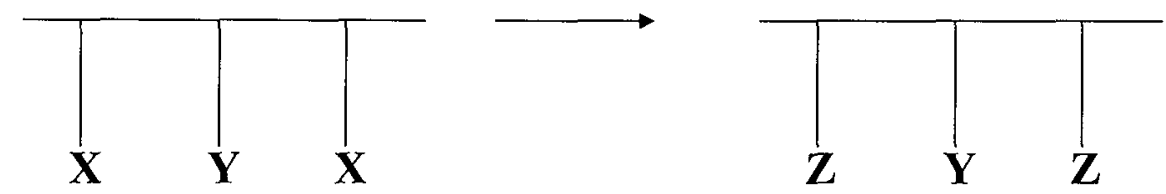

C
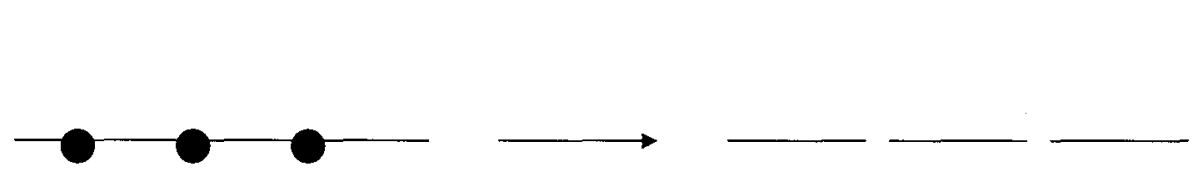

Scheme 1.1: Three different breakdown mechanisms of biodegradable polymers;

hydrolyzable bond; $(X \rightarrow$ Z) hydrolysis, ionization, protonation, $(Y)$ hydrophobic component.

On a macroscopic level degradation can occur via surface erosion or bulk erosion. Bulk erosion implies that degradation occurs simultaneously at the surface and in the bulk of a polymeric material. Hydrogels composed of poly(lactic acid), poly(glycolic acid) and their copolymers are known to exhibit this form of degradation, due to the fact that the acidic degradation products autocatalyze the degradation. Surface erosion on the other hand implies that degradation only takes place at the surface of a material. In many cases surface erosion is preferred over bulk erosion, due to the controlled manner of degradation. This pattern of degradation is seen in poly(anhydrides). ${ }^{49}$ 


\subsubsection{Hydrogels in drug delivery formulations}

Recent developments address the use of smart water-swollen (crosslinked or not) biomaterials as carriers of drugs for local administration. ${ }^{51-56}$ They are found to diminish systemic effects compared to conventional drug administration methods. Depending on their application they are introduced into the human body as drugloaded microspheres, patches and reservoirs. Oral, rectal, ocular, epidermal, and subcutaneous drug delivery systems have been developed, in order to achieve this site-specific drug administration. For instance, insulin may be delivered only when needed, calcitonin may be directed to bypass the stomach intestine, and large genetically-engineered molecules are delivered across tissue at acceptable rates. Not only do they release the drug topically, they also provide the desirable protection of the incorporated drugs from the potentially harsh environment in the vicinity of the release site.

The network structure plays a key role in the drug delivery process. Controlled drug release can be accomplished by swelling controlled release or by phase erosion controlled. Swelling controlled release is based on a polymeric carrier, which exhibits swelling in the presence of a biological fluid. The incorporated drug is able to diffuse out of the hydrogel into the surrounding environment. In the case of the of phase erosion, the drug is released due to simple dissolution or degradation of the matrix.

\subsection{Hydrogels in ophthalmology}

Hydrogels have found numerous applications in the field of ophthalmology. ${ }^{51}$ Contact lenses and intra-ocular lenses are the two mayor uses of polymers in ophthalmology. Furthermore, drainage pipes for glaucoma patients, implants to treat retinal detachment, and surgical adhesives are also used. Initially, materials as poly(MMA) were used. The hydrophobic nature of these materials causes discomfort and damage to the cornea ${ }^{58,59}$ As a consequence emphasis was placed on 
more hydrophilic materials based on poly(NVP) and poly(HEMA). For instance, Chirila et al. found that crosslinked poly(NVP) hydrogels possesses useful properties in vitreous substitute formulations. ${ }^{60-64}$ Recent developments of e.g. keratoprosthesis, and drug delivery systems benefit from these findings, since the hydrophilic polymers are adequately equipped for these applications. In this thesis research concerning: (i), ocular drug delivery systems; and (ii), the development of corneal implants will be discussed. First, the anatomy of the eye is outlined.

\subsubsection{Anatomy of the eye}

The human eye contains vascularized areas such as the ciliary body and choroid, and non-vascularized areas such as the cornea and lens, all of which have very specific functions. ${ }^{65}$

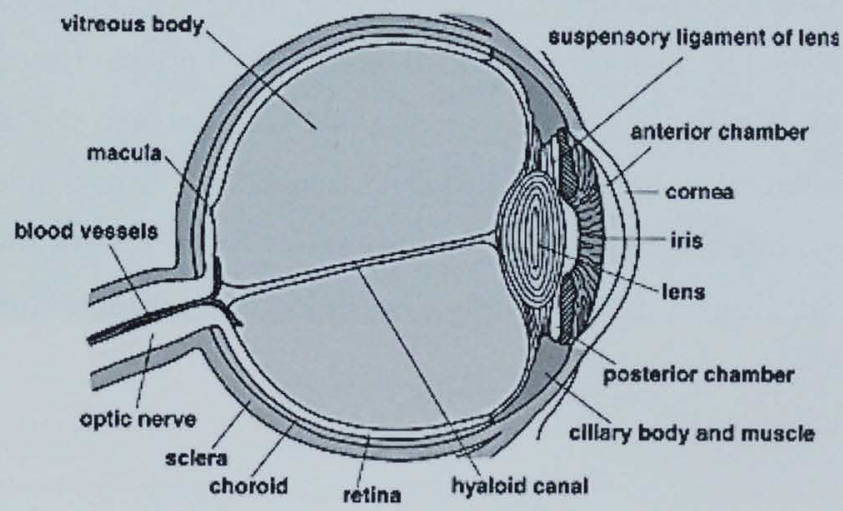

Figure 1.1: A schematic representation of the human eye.

A schematic representation of the eye is given in Figure 1.1. A short description of the most important sections is outlined here.

Posterior chamber: the back section of the eye's interior. 
Anterior chamber:

Cornea:

Vitreous body:

Sclera:

Lens:

Retina:

Optic nerve:

Macula:

Iris: the front section of the eye's interior where aqueous humor flows in and out, providing nourishment to the eye and surrounding tissues.

the transparent, dome-shaped window of the eye is mainly composed of collagen fibrils arranged in an orderly fashion that permits the transmission of light energy. The cornea is responsible for focusing approximately $70 \%$ of the light rays entering the eye onto the retina. The cornea hardly contains any cells and no blood vessels and consists of five distinct layers: the epithelium, Bowman's (anterior limiting) membrane, stroma (substantia propia), Descemet's (posterior limiting) membrane, and endothelium.

consists of a clear jelly-like substance that fills the center of the eye.

the white visible part of the eyeball.

transparent and crystalline structure inside the eye that focuses light rays onto the retina.

the light sensitive nerve layer that lines the back of the eye. The retina senses light and creates impulses that are sent through the optic nerve to the brain.

a bundle of more than 1 million nerve fibers that connects the retina with the brain. The optic nerve is responsible for interpreting the impulses it receives to images.

the portion of the eye that allows us to see fine details clearly.

the colored part of the eye. It is partly responsible for regulating the amount of light permitted to enter the eye. 


\subsubsection{Ocular drug delivery systems}

Adequate treatment of eye diseases requires high local concentrations of therapeutic agents for prolonged periods of time. ${ }^{51}$ Many administration methods, such as intravenous injections, intravitreous injections and eye-drops have been employed to achieve control over these diseases. ${ }^{6677}$ These therapies all have considerable side effects. For example, frequent injections in the vitreous body of the eye have proven to be very effective. Repeated intravitreous injections are usually necessary to maintain therapeutic levels, because of the short half-life of the drug. Serious adverse reactions, such as cataract, retinal detachment and endopthalmitis are, however, relatively common. Conventional ocular drug delivery through eye-drops and ointments also gives rise to various problems. The protective mechanisms of the eye, such as effective tear drainage, blinking and low permeability of the cornea and sclera, result in quick clearance of the drug from the eye. Poor bioavailability (it has been found that as little as $1 \%$ may reach the anterior chamber of the eye), as well as discomfort to the patient, are the major drawbacks of eye drops and ointments.

Degradable drug delivery systems tend to bypass various negative aspects of the conventional methods. These systems can be implanted at the site of the disease and diffusion through the blood-retina barriers and the tough sclera and/or cornea is avoided. Furthermore, a degradable drug delivery device effectively circumvents the necessity of frequent administration of a drug. The system can be designed such that drug concentrations maintain at therapeutic levels for prolonged periods of time. Ideally, the matrix degrades simultaneously, and there is also no need for removal of the implant.

Various degradable matrices have been studied with regard to this application. ${ }^{51}$ Collagen shields shaped as contact lenses were developed and marketed with the intention to deliver antibacterial, anti-fungal and anti-inflammatory agents to treat dry eyes. It was encountered that these systems cause discomfort and interfere with vision. Collagen shields with 5-fluorouracil (5-FU) were found to function satisfactorily and thus improved the quality of glaucoma-filtration surgery. Also 
completely soluble systems as polyethylacrylate, poly(NVP), and poly(acrylamide) systems were investigated with regard to their ability to prolong the bio-availability of active ingredients in the conjunctival fluid. Sixty to ninety minutes were necessary for the system to dissolve, whereas a therapeutic activity of more than 24 $\mathrm{h}$ was accomplished. Kimura $e t$ al. found that poly(lactic acid) microspheres loaded with adriamycin succeeded in decreasing the intra ocular pressure and preventing proliferation of fibroblasts after glaucoma surgery. Drug release was maintained for 20 days. $^{72}$

Poly(lactic-co-glycolic acid) systems are the most popular polymeric matrix for drug delivery, due to the fact that they are food and drug administration (FDA) approved for this application. Despite this fact numerous applications of these materials lead to inflammatory responses, simply because acidic degradation products are released in a burst effect. ${ }^{50}$ Here, we consider an entirely different approach of drug delivery, based on crosslinked poly(NVP) and crosslinked poly(dimethylethylamino methacrylate) (poly(DMAEMA), of which we believe that these inverse reactions are absent.

\subsubsection{Hydrogels as corneal implants}

Surgical replacement of diseased or injured corneas with donor corneas, has become a routine procedure. ${ }^{73}$ Despite this fact, there are problems as the unavailability or recurrent rejection of donor material. Recurrent rejections can take place in patients suffering from auto-immune diseases, as rheumatoid arthritis. Corneal thinning which can result in a corneal perforation, is frequently seen in these patients. ${ }^{7 t}$ To solve these problems there are several strategies: (i), use of a permanent keratoprosthesis; or (ii), down-regulation of the immune response of the patient followed by the placement of allograft material. ${ }^{75-78}$ The latter method may require a temporary solution, e.g. in the case of a penetrated cornea. During medication, the patient needs temporary closure of the corneal perforation. NeuroPatch $^{\circledast}$, a non transparent biocompatible polyurethane, has been used on several 
occasions. $^{79}$ It will be clear that developing an alternative biomaterial which combines the biocompatibility of Neuro-Patch ${ }^{\circledast}$ with optical transparency for this purpose is very challenging.

Initially, rigid and impermeable materials were used to fabricate corneal implants. Later on Cardona devices were used. ${ }^{80}$ These devices were complex and included a poly(MMA) optic surrounded by a perforated skirt of poly(tetrafluoroethylene) reinforced with a mesh composed of poly(ethylene teraphthalate) and autologous tissue. The procedure of implantation was also very complicated. Porous materials were thought to be more successful than these systems. In this thesis emphasis is placed on the development of polymeric hydrogels suitable for the intended applications.

\subsection{Biocompatibility and cytotoxicity of hydrogels}

The biocompatibility of a biomaterial is tested via the following parameters:

(i), the biomaterial must not cause severe deleterious effects on the organism. This encompasses cytotoxicity, mutagenesis and carcinogenesis (biosafety);

(ii), the biomaterial must possess the ability to perform with an appropriate host response (no adverse reactions, such as inflammatory reactions or immune responses) in a specific application (biofunctionality). ${ }^{81-84}$

Biocompatibility assays involve the demonstration of cell proliferation. Materials, which sustain or promote cell proliferation are considered to be biocompatible.

Cytotoxic biomaterials lead to unwanted effects for contacting cells, e.g.(death or alterations in cellular membrane permeability). Cytotoxic effects are frequently seen when biomaterials are tested. Hydrogels often leach unreacted monomers, oligomers and/or initiators during application. Extensive washings and the preparation of hydrogels without initiator (use of $\gamma$-irradiation) can eliminate the cause of cytotoxicity.

There are several cell culture methods available to evaluate the cytotoxicity (biosafety) of hydrogels before implantation into living systems. Important 
principles of these tests are: the inclusion of positive and negative control materials, extraction conditions, choice of cell lines and cell media, as well as important aspects of the test procedures, including tests on extracts, and tests by direct and indirect contact. Cytotoxicity can be assessed via the MTT test, DNA synthesis and membrane integrity tests. In this thesis emphasize is placed on the MTT assay.

The MTT assay, a quantifiable test, is a measure of cell metabolic function, depending on the intact activity of a mitochondrial enzyme, succinate dehydrogenase, which is impaired after exposure of cells to toxic surroundings. Although the widespread acceptance of the assay, there is certainly a need to continue searching for improvements.

Studies concerning in vitro biofunctionality for a specific function, aim at establishing reproducible and quantifiable assays. These assays focus on the cells involved and on the biological parameters relevant to the medical device application. Parameters which are investigated are: cell adhesion, cell spreading, cell proliferation and cell biosynthetic function.

\subsection{Aim and outline of this thesis}

This thesis deals with the development of hydrogels suitable as: (i), a degradable matrix for site-specific drug delivery; or (ii), a non-degradable temporary corneal implant.

Ad(i): Chemical, physical, and biological properties of hydrogels can be engineered such that good agreement with the intended function and natural tissue is achieved. This implies that there must be accurate control over swelling, degradation times (drug release times) and biocompatibility. The development of degradable matrices, which allow control over degradation, swelling and biocompatibility is described in this thesis. All systems are based on the same concept. Basically, all materials are water-soluble polymers (poly(NVP) or poly(DMAEMA)), crosslinked by various amounts of a new degradable crosslinker, 1. Depending on the amount of this crosslinker incorporated, swelling and degradation of the system can be controlled. Also the cell-biomaterial interaction was studied in vitro and in vivo. 
Ad(ii): Hydrogels are also useful as possible corneal implants. The development of a biomaterial for temporary replacement of diseased or damaged corneal tissue is also discussed in this thesis. The hydrogel must have similar physical properties (including transparency) as the cornea. The polymeric system is based on the use of a copolymer of hexaethyleneglycol methacrylate (HEGMA) and n-butyl methacrylate (BMA). The characteristics of materials with variable amounts of the hydrophilic HEGMA were studied with regard to this application.

Chapter 2 deals with three-dimensional networks of poly(NVP) crosslinked by 1 . Synthesis and characterization of this novel degradable crosslinker as well as the preparation of three degradable materials with various NVP content is described. Swelling and degradation characteristics were studied in vitro. The materials were also implanted in rabbit eyes to evaluate their biocompatibility.

Chapter 3 describes degradable systems based on DMAEMA and 1. The preparation of copolymers with different contents of DMAEMA, is described. The relative reactivity during the solution copolymerization of these two methacrylates was studied. In addition, the reactivity of NVP and HEMA was measured. Free monomer content was investigated by means of fourier transform infrared spectroscopy (FT-IR) and ${ }^{~} \mathrm{H}$ NMR. Dynamic mechanical thermal analysis (DMTA) was used to determine the glass transition temperatures (Tg's). Scanning electron microscopy (SEM) analysis of the various materials in different degradation stages is described. Furthermore the degradation and swelling characteristics were determined and a MTT assay was employed to evaluate the cytotoxicity.

Chapter 4 deals with monitoring water uptake (swelling) of copolymers based on NVP and 1, and NVP and a stable crosslinker (tetraethyleneglycol dimethacrylate) with NMR microimaging, a non-invasive technique. Water uptake and decomposition of materials with different crosslinker content was investigated. The suitability of materials with different crosslinker concentrations for the use as drug delivery system was examined. 
Chapter 5 deals with biomaterials, of which is expected that they are suitable as a temporary corneal closure. These materials are copolymers of HEGMA and BMA. Materials with different HEGMA contents were prepared. The influence on the suitability as a corneal implant was investigated by means of the following techniques: Wilhelmy contact angle, water uptake, NMR microimaging, differential scanning calorimetry (DSC), light transmittance, thermal gravimetric analysis (TGA) and FT-IR spectroscopy measurements. Resistance to protein adhesion was also studied by means of X-ray photo-electron spectroscopy (XPS) and matrixassisted Laser Desorption Ionization time of flight (MALDI-TOF). Cytotoxicity and biocompatibility assays were also conducted.

\subsection{References}

1. Lantos, P.R. J. Biomed. Appl. 1998, 2, 358.

2. Yoda, R. J. Biomater. Sci. Polymer Edn. 1998, 9, 561.

3. Hunter, T.B. Curr. Probl. Diagn. Radiol. 1995, 24, 53.

4. Aronoff, M.S. J. Biomater. Appl. 1995, 9, 205.

5. Langer, R. AICHE. J. 2000, 46, 1286.

6. Rockwood, E.J.; Larive, B.; Hahn, J. Am. J. Opthalmol. 2000, 130, 704.

7. Bobrow, J.C. Trans. Am. Ophthalmol. Soc. 1998, 96, 521.

8. Macnair, R.; Underwood, M.J.; Angelini, G.D. Proc. Inst. Mech. Eng. [H] 1998, 212, 465.

9. Disegi, J.A.; Eschbach, L. Injury Int. J. Care Injured 2000, 31 Suppl. 4, S2-S6.

10. Schildhauer, T.A.; Gekle, C.J.E.; Muhr, G. Chirurg 1999, 70, 888.

11. Yen, S.K.; Hsu, S.W. J. Bioned. Mater. Res. 2001, 54, 412.

12. Niinomi, M. Mater. Sci. Eng. A Struct. Mater. 1998, 243, 231.

13. Gresty, M.; Brookes, G. Curr. Opin. Neurol. 1997, 10, 36.

14. Serry, T.A.; Blamey, P.J. J. Speech Lang. Hear. Res. 1999, 42, 141.

15. Lee, D.S.; Lee, J.S.; Oh, S.H.; Kim, S.K.; Kim, J.W.; Chung, J.K.; Lee, M.C.; Kim, C.S. Nature 2001, $409,149$.

16. Geurts, L.; Wouter, I. J. Acoust. Soc. Ant. 2000, 108, 2949.

17. Tsuji, T.; Tamai, H.; Igaki, K.; Kyo, E.; Kosuga, K.; Hata, T.; Okada, M.; Nakamura, T.; Komori, H.; Motohara, S.; Uehata, H. Curr. Intervent. Cardiol. Rep. 2001, 3, 10.

18. Alberti, A.; Missiroli, B.; Nannini, C. J. Invasize Cardiol. 2000, 12, 633. 
19. Meyer, J.M.; Buecker, A.; Schuermann, K.; Ruebben, A.; Guenther, R.W. Invest. Radiol, 2000, 35, 739.

20. Liberman, H.; Adams D.R.; Blatchford G.J.; Ternent C.A.; Christensen M.A.; Thorson A.G. Am. J. Surg. 2000, 180, 407.

21. Chen, F.; Yoo, J.J.; Atala, A. Urology 1999, 54, 407.

22. Mousa, W.F.; Kobayashi, M.; Shinzato, S.; Kamimura, M.; Neo, M.; Yoshihara, S.; Nakamura, T. Biomaterials 2000, 21, 2137.

23. Davies, J.P.; Singer, G.; Harris, W.H. J. Appl. Biomater. 1992, 3, 45.

24. Shepard, M.F.; Kabo, J.M.; Lieberman, J.R. Clin. Orthop. 2000, 381, 26.

25. Li, D.J.; Ohsaki, K.; Li, K.; Cui, P.C.; Ye, Q.; Baba, K.; Wang, Q.C.; Tenshin, S.; TakanoYamamoto, T. J. Biomed. Mater. Res. 1999, 45, 322.

26. Urry, D.W.; Pattanaik, A.; Xu, J.; Woods, T.C.; McPerson, D.T.; Parker, T.M. J. Biomater. Sci. Polymer Edn. 1998, 9, 1015.

27. Hukins, D.W.L.; Leahy, J.C.; Mathias, K.J. J. Mater. Chem. 1999, 9, 629.

28. Burg, K.J.; Allan, J.M.; Roweton, S.L.; Shalaby, S.W. Ann. N. Y. Acad. Sci. 1997 831, 217.

29. Peppas, N.A.; Huang, Y.; Torres-Lugo, M.; Ward, J.H.; Zhang, J. Ann. Rev. Biomed. Eng. 2000, 2, 9.

30. Bruining, M.J.; Edelbroek-Hoogendoorn, P.S.; Blaauwgeers, H.G.T.; Mooy, C.M.; Hendrikse, F.H.; Koole, L.H. J. Biomed. Mater. Res. 1999, 47, 189.

31. Bruining, M.J.; Blaauwgeers, H.G.T.; Kuijer, R.; Pels, E.; Nuijts, R.M.M.A.; Koole, L.H. Biomaterials 2000, 21, 595.

32. Bruining, M.J.; Blaauwgeers, H.G.T.; Kuijer, R.; Jongsma, F.H.M.; de Brabander, J.; Nuijts, R.M.M.A.; Koole, L.H. Bio-Macromolecules 2000, 1, 418.

33. Scott-Burden, T.; Tock, C.L.; Schwarz, J.J.; Casscells, S.W.; Engler, D.A. Circulation 1996, 1:94(9 Suppl), II235.

34. Efron, N.; Morgan, P.B. CLAO. J. 1999, 25, 148.

35. Peppas, N.A.; Bures, P.; Leobandung, W.; Ichikawa, H. Eur. J. Pharm. Biopharm. 2000, $50,27$.

36. Gomez-Orellana, I.; Paton, D.R. Expert Opin. Ther. Patents 1999, 9, 247.

37. Davies, M.L.; Murphy, S.M.; Hamilton, C.J.; Tighe, B.J. Biomaterials 1992, $13,991$.

38. Young, C.D.; Wu, J.R.; Tsou, T.L. Biomaterials 1998, 19, 1745.

39. Woerly, S. Porous Materials for Tissue Engineering 1997, 250, 53.

40. Dittgen, M.; Durrani, M.; Lehmann, K., STP. Pharm. Sciences 1997, 7, 403.

41. Miller, D.R.; Peppas, N.A. Biomaterials 1986, 7, 329.

42. Hyon, S.H. Yonsei Med. J. 2000, 41, 720.

43. Shantha, K.L.; Harding, D.R. Int. J. Pharm. 2000, 207, 65.

44. Blanco, M.D.; Garcia, O.; Gomez, C.; Sastre, R.L.; Teijon, J.M. J. Pharm. Pharmacol. 2000, 52, 1319.

45. Wheatley, D.J.; Bernacca, G.M.; Tolland, M.M.; O'Connor, B.; Fisher, J.; Williams, D.F. Int. J. Artif. Organs 2001, 24, 95. 
46. Shalaby, W.S.; Blevins, W.E.; Park, K. Biomaterials 1992, 13, 289.

47. Bettini, R.; Catelanni, P.L.; Santi, P.; Massimo, G.; Peppas, N.A.; Colombo, P. J. Control. Release 2001, 70, 383.

48. Lu, L.; Stamatas, G.N.; Mikos, A.G. J. Biomed. Mater. Res. 2000, 50, 440.

49. Göpferich, A. Biomaterials 1996, 17, 103.

50. Suming, L.; Mccarthy, S. Biomaterials 1999, 20, 35.

51. Deshpande, A.A.; Heller, J.; Gurny, R. Crit. Rev. Ther. Drug Carr. Syst. 1998, 15, 381.

52. Moritera, T.; Ogura, Y.; Yoshimura, N.; Honda, Y.; Wada, R.; Hyon, S.; Ikada, Y. Invest. Ophthalmol. 1992, 13,3125.

53. Moritera, T.; Ogura, Y.; Yoshimura, N.; Honda, Y.; Wada, R.; Hyon, S.; Ikada, Y. Invest. Ophthalmol. Vis. Sci. 1991, 32, 1785.

54. Jain, R.A. Biomaterials $2000,21,2475$.

55. Orienti, I.; Di Pietra, A.; Luppi, B.; Zecchi, V. Arch. Pharm. 2000, 333, 421.

56. Lowman, A.M.; Morishita, M.; Kaijta, M.; Nagai, T.; Peppas, N.A. J. Pharm. Sci. 1999, 88, 933.

57. Singh, J.; Agrawal, K.; Ray, A.R.; Singhal, J.P.; Singh, H.; Dada, V.K.; Mehta, M.R. J. Biomed. Mater. Res. 1992, 26, 1253.

58. Lanza, R.P.; Langer, R.; Vacanti, J. In: "Principles of Tissue Engineering,"Academic Press, San Diego, CA, 1997, 471.

59. Garrett, Q.; Laycock, B.; Garrett, R.W. Invest. Ophthalmol. Vis. Sci. 2000, 41, 1687.

60. Vijayasekaran, S.; Chirila, T.V.; Hong, X.; Tahija, S.G.; Dalton, P.D.; Constable, I.J.; McAllister, I.L. J. Biomed. Sci. Polymer Edn. 1996, 7, 685.

61. Hong, Y.; Chirila, T.V.; Cuypers, J.H.; Constable, I.J. J. Biomaterials Applications 1996, 11, 135.

62. Hong, Y.; Chirila, T.V.; Vijayasekaran, S.; Shen, W.; Lou, X.; Dalton, P.D. J. Biomed. Mater. Res. $1998,39,650$.

63. Hong, Y.; Chirila, T.V.; Vijayasekaran, S.G.; Dalton, P.D.; Tahija, S.G.; Cuypers, M.J.H.; Constable, I.J. J. Biomed. Mater. Res. 1996, 30, 441.

64. Wesendahl, T.A.; Shalaby, W.; Corson, D.W.; Auffarth, G.U.; Apple, D.J. Opthalmol. 1996, 93, 22.

65. Lanza, R.P.; Langer, R.; Vacanti, J. In: " Principles of Tissue Engineering,"Academic Press, San Diego, CA, 1997, 435.

66. Martin, D.F.; Parks, D.J.; Mellow, S.D.; Ferris, F.L.; Walton, R.C.; Remaley, N.A.; Chew, E.Y.; Ashton, P.; Davis, M.D.; Nussenblatt, R.B. Arch. Ophthalmol. 1994, 112, 1531.

67. Morley, M.G.; Duker, J.S.; Ashton, P.; Robinson, M.R. Opthalmol. 1995,102, 388.

68. Kunou, N.; Ogura, Y.; Hashizoe, M.; Honda, Y.; Hyon, S.; Ikada, Y. J. Control. Release 1995, 37, 143.

69. Hashizoe, M.; Ogura, Y.; Takanashi, T.; Kunou, N.; Honda, X.; Ikada, Y. Curr. Eye Res. 1997, 16, 633. 
70. Ussery, F.M.; Gibson, S.R.; Conklin, R.H.; Piot, D.F.; Stool, E.W.; Conklin, A.J. Opthalmol. 1988, 95,640 .

71. Veloso, A.A.S.; Zhu, Q.; Herrero-Vanrell, R.; Refojo, M.F. Invest. Ophthalmol. Vis. Sci. 1997, 38, 665.

72. Kimura, H.; Ogura, Y.; Moritera, T.; Honda, Y.; Wada, R.; Hyon, S.H.; Ikada, Y. Invest. Opthalmol. Vis. Sci. 1992, 33, 3436.

73. Cheng, C.L.; Tan, D.T.H. Aus. N.Z. J. Opthalmol. 1999, 27, 437.

74. Lekskul, M.; Fracht, H.U.; Cohen, E.J.; Rapuano, C.J.; Laibson, P.R. Cornea 2000, 19, 313.

75. Vote, B.J.; Elder, M.J. Clin. Experiment Ophthalmol. 2000, $28,437$.

76. Yaghouti, F.; Nouri, M.; Abad, J.C.; Power, W.J.; Doane, M.G.; Dohlman, C.H. Cornea 2001, 20, 19.

77. Chern, K.C.; Meisler, D.M.; Wilson, S.E.; Macsai, M.S.; Krasney, R.H. Ophthalmol. 1997, 104, 643.

78. Hicks, C.; Crawford, G.; Chirila, T.; Wiffen, S.; Vijayasekaran, S.; Lou, X.; Fitton, J.; Maley, M.; Clayton, A.; Dalton, P.; Platten, S.; Ziegelaar, B.; Hong, Y.; Russo, A.; Constable, I. Prog. Ret. Eye Res. 2000, 19, 149.

79. Nuijts, R.M.M.A.; Kooijman-de Groot, M.J.C.; Prins, M.; Pels, E. Arch.Ophthalmol. 1999, 117, 1427.

80. Lanza, R.P.; Langer, R.; Vacanti, J. In: "Principles of Tissue Engineering,"Academic Press, San Diego, CA, 1997, 478.

81. Kirkpatrick, C.J.; Bittinger, F.; Wagner, M.; Köhler, H.; van Kooten, T.G.; Klein, C.L.; Otto, M. Proc. Inst. Mech. Eng. [H]. 1998, 212, 75.

82. Kirkpatrick, C. J. Med. Device Technol. 1998, 9, 22.

83. Mohr, W.; Kirkpatrick, C.J. Aktuelle Probl. Chir. Orthop. 1983, 26, 18.

84. Yoshii, E. J. Biomed. Mater. Res. 1997, 37, 517. 


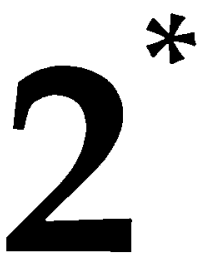

New Biodegradable Networks of Poly(1vinyl-2-pyrrolidinone), Designed for Controlled Non-Burst Degradation in

\section{the Vitreous Body}




\section{Summary}

Polymers of 1-vinyl-2-pyrrolidinone (NVP) are known to have excellent biocompatibility when implanted in the vitreous body, or even as vitreous substitute. While poly(NVP) is capable of absorbing relatively large amounts of water, it is not prone to hydrolysis. Yet, intraocular degradation of several crosslinked poly(NVP) hydrogels has been reported recently, but there remains some ambiguity about the exact mechanism of degradation of these materials. To date, there is no biomaterial which combines the excellent intraocular biocompatibility on one hand, and controlled kinetics of degradation on the other hand.

We attempted to design and prepare such materials through the chemical synthesis of a novel dimethacrylate crosslinker molecule. The essential feature of this molecule is that its core contains two carbonate groups, which are -evidentlysusceptible to hydrolytic scission. We studied a series of three-dimensional networks of poly(NVP), crosslinked by this molecule. This approach offers several advantages: (i), hydrolysis of the carbonate groups in the crosslinks leads to liberation of poly(NVP) and/or oligo(NVP) chains which can probably be cleared from the eye via phagocytosis; (ii), hydrolysis generates two alcohols and $\mathrm{CO}_{2}$ i.e. there is no catalytic burst-effect; (iii), when these materials are implanted in dry form, swelling and degradation will progress from the exterior of the material toward its interior. Therefore, these materials can be designed such that surface degradation rather than bulk degradation occurs; (iv), the hydrolysis rate can be controlled via the crosslink density or through synthesis of other crosslink molecules with either more ( $>2$ ) or less (1) carbonate groups, or -alternatively - with one or more other labile groups.

In this chapter, the chemical synthesis of the crosslinker molecule, as well as the preparation and degradation of a series of poly(NVP)-based hydrogels in vitro and in vivo (rabbit eyes) is reported. It was found that these materials indeed display excellent biocompatibility in the rabbit eye. Furthermore, the experiments confirmed that degradation occurs without burst-effect. The results are in line with 
the idea that the rate of intraocular swelling and degradation depends on the crosslink density, but this is only a preliminary conclusion, which must be strengthened by much more experimental work. Nonetheless, several applications of these or related materials in ophthalmology, e.g., as biodegradable matrix materials for controlled drug delivery of ganciclovir in the vitreous body are foreseen.

\section{$2.1 \quad$ Introduction}

Controlled drug delivery in the vitreous body of the eye poses substantial conceptual and technical problems. Significant progress in this field was made during the last decade. These developments were stimulated in part by clinical evidence that cytomegalovirus (CMV) retinitis (the major cause of visual loss in AIDS patients) can best be treated via sustained intraocular delivery of ganciclovir. ${ }^{1.5}$ Among the most promising approaches are those that are based on the use of biodegradable polymeric biomaterials as matrices which release ganciclovir in their environment. Grossly speaking, two approaches can be distinguished: (i), use of a biodegradable ganciclovir-loaded scleral plug. The polymeric plug is implanted at the pars plana, and it releases ganciclovir in the vitreous body while it gradually degrades and disappears. ${ }^{6.8}$ This strategy is potentially useful for the treatment of CMV retinitis, as was shown in several studies using rabbit models. (ii), use of ganciclovir-loaded polymeric microspheres. ${ }^{9}$ The microspheres consist of a biodegradable polymeric matrix material, and are injected in the vitreous body via the pars plana. The micropsheres gradually degrade and simultaneously release the drug into their environment.

Ideally, the degradation of the polymeric matrix obeys zero-order kinetics, and oligomeric and monomeric remnants of the matrix structure are excreted from the eye without exerting any harmful side-effects. Most of the current knowledge on intraocular use of biodegradable biomaterials refers to poly(lactic acid) or poly(D,Llactic-co-glycolic acid). The major advantage of these materials is that their 
degradation ultimately results in metabolic products (lactic acid, glycolic acid). On the other hand, however, the clearance time of these materials appeared to be a complex function of many parameters (e.g., molecular weight, porosity, crystallinity, and size of the particles). Therefore, it is difficult to ensure reproducibility regarding the kinetics of intraocular drug release. ${ }^{10 \cdot 13}$ Furthermore, it should be borne in mind that poly(lactic acid) and poly(D,L-lactic-co-glycolic acid) show burst-degradation, i.e. a sudden acceleration in their breakdown is seen long after implantation. Moreover, it is known that microspheres of poly(lactic acid) and poly(D,L-lactic-co-glycolic acid) or their decomposition products can cause a foreign body reaction as well as glial and fibroblastic proliferation. ${ }^{13}$

The design and synthesis of a new family of biodegradable biomaterials, which may be useful to overcome some of the typical problems of poly(lactic acid) or poly(D,Llactic-co-glycolic acid), as far as intraocular applications are concerned, are reported here. The new materials consist of crosslinked poly(NVP), and closely resemble materials which were studied extensively as vitreous substituents. ${ }^{1417}$ These materials can absorb large amount of water and then become hydrogels with viscoelastic behavior. The essential feature of the novel materials described here, is that the poly(NVP) chains are crosslinked via the bifunctional dimethacrylate structure 1 (Figure 2.1), which contains two labile carbonate groups. Hydrolytic scission of the carbonate groups liberates $\mathrm{CO}_{2}$ and free oligo(NVP) and/or

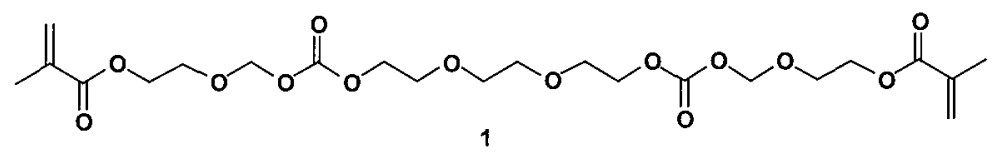

Figure 2.1: Structural formula of the biodegradable crosslinker molecule, 1. Note the two methacrylate groups at the terminal ends, and the two carbonate groups in the core section of the molecular structure. Purity and identity of were established by means of NMR spectroscopy $\left({ }^{3} \mathrm{H},{ }^{13} \mathrm{C}\right)$ and mass spectrometry.

poly(NVP) chains. Recently, it was postulated by Chirila et al. that fragments of poly(NVP)-based hydrogels can be removed from the vitreous through 
phagocytosis. ${ }^{15.18,19}$ Most probably, remnants of the hydrogel can be ingested by phagocytes, and subsequently be transported out of the cavity via the posterior clearance pathway, i.e. via the optical nerve. We observed that the degradation kinetics can be controlled using the novel biomaterials described herein: increasing the crosslink density results in slower swelling and slower degradation.

This chapter describes: (i), chemical synthesis of $\mathbf{1}$; (ii), preparation of three different biodegradable materials: material A (molar ratio $1: \mathrm{NVP}=1: 10.5$ ); material $\mathrm{B}$ (molar ratio $1: \mathrm{NVP}=1: 100.5)$, material C (molar ratio $1: \mathrm{NVP}=1: 1000$ ), material $\mathrm{D}$ (poly(NVP), material E (molar ratio tetraethyleneglycol dimethacrylate (TEGDMA (2)) : NVP = $1: 10.5$ ); material $\mathrm{F}$ (molar ratio $2: \mathrm{NVP}=1: 100.5$ ) and material G (molar ratio $2: \mathrm{NVP}=1: 1000$ ); (iii), studies into swelling and degradation of materials $\mathrm{A}-\mathrm{C}$ and several reference materials in vitro; (iv), studies of swelling, degradation and biocompatibility of materials $\mathrm{A}-\mathrm{C}$ in the rabbit eye.

\subsection{Experimental section}

\subsubsection{Materials}

\section{a) Chemicals}

All solvents and starting materials were of the highest available purity or were purified as specified. Commercial 2-hydroxyethyl methacrylate (HEMA) and NVP were distilled under reduced pressure. Preruns of approximately $50 \mathrm{~mL}$ were discarded. The main fractions were collected and stored at $-18{ }^{\circ} \mathrm{C}$. Triethylene glycol was stripped with dry toluene. $N, N$-dimethylformamide (DMF) was distilled over calcium hydride and stored over Linde $3 \AA$ molecular sieves. Silica gel 60 (particle size $0.063-0.200 \mathrm{~mm}$ ) was used for column chromatography. Thin layer chromatography was performed on glass plates $(3 \times 10 \mathrm{~cm})$ with a fluorescent indicator. 


\section{b) Preparation of the biodegradable crosslinker and the polymeric networks}

The preparation of the different biodegradable networks comprises two steps: (i), the synthesis of the degradable bifunctional monomer 1; (ii), the photocopolymerization of 1 with NVP.

Ad (i): The synthetic route to carbonates, as described by Teranishi et al. was used, viz. Scheme $2.1 .^{20}$ Reaction (a): Thionylchloride (49.7 g, $\left.0.42 \mathrm{~mol}\right)$ was added dropwise to a stirred and cooled mixture $\left(0-5{ }^{\circ} \mathrm{C}\right)$ of HEMA $(80.4 \mathrm{~g}, 0.62 \mathrm{~mol})$ and paraformaldehyde $(18.9 \mathrm{~g}, 0.63 \mathrm{~mol})$. After completion of the addition, stirring was continued for 10 minutes. The reaction mixture was transferred to a separatory<smiles>C=C(C)C(O)OCCO</smiles>

(a)<smiles>C=C(C)C(=O)OCCOCCl</smiles><smiles>C=C(C)C(=O)OCCOCCOC(=O)OCCOCCOCCOC(=O)OCOCCOC(=O)C(=C)C</smiles>

(b)<smiles>OCCOCCOCCO</smiles>

Scheme 2.1: Synthesis of the biodegradable crosslinker: (a) $\mathrm{SOCl}_{2^{\prime}}\left(\mathrm{CH}_{2} \mathrm{O}\right)_{n^{\prime}} \mathrm{O}-5^{\circ} \mathrm{C}$; and (b) $\mathrm{Ag}_{2} \mathrm{CO}_{3^{\prime}} \mathrm{DMF}$, $15^{\circ} \mathrm{C}$.

funnel and ice-water was added. Two extractions with dichloromethane were performed. The organic phases were combined, dried $\left(\mathrm{Na}_{2} \mathrm{SO}_{4}\right)$ and concentrated. Vacuum distillation afforded pure compound 3 (chloromethylene-oxyethylmethacrylate) as a colorless liquid (58.11 $\mathrm{g}, 0.33 \mathrm{~mol}, 53 \%)$.

${ }^{1} \mathrm{H} \mathrm{NMR}\left(\mathrm{CDCl}_{3}\right): \delta 1.95(3 \mathrm{H}, \mathrm{s}, \mathrm{Me}), 3.92\left(2 \mathrm{H}, \mathrm{t}, \mathrm{OCH}_{2} \mathrm{CH}_{2} \mathrm{OCH}_{2} \mathrm{Cl}\right), 4.34(2 \mathrm{H}, \mathrm{t}$, $\left.\mathrm{OCH}_{2} \mathrm{CH}_{2} \mathrm{OCH}_{2} \mathrm{Cl}\right), 5.48\left(2 \mathrm{H}, \mathrm{s}, \mathrm{OCH}_{2} \mathrm{Cl}\right), 5.60(1 \mathrm{H}, \mathrm{m}$, olef. $\mathrm{H}), 6.15(1 \mathrm{H}, \mathrm{m}$, olef. $\mathrm{H})$.

${ }^{13} \mathrm{C}$ NMR $\left(\mathrm{CDCl}_{3}\right): \delta 166.51,135.41,125.43,82.13,67.49,62.24,17.67$.

FAB-MS calcd for $\mathrm{C}_{7} \mathrm{H}_{11} \mathrm{O}_{3} \mathrm{Cl}\left(\mathrm{M}^{+}+\mathrm{H}\right) \mathrm{m} / \mathrm{z}$ 179.623, found 179.0470 . 
Reaction (b) : Silvercarbonate $(17.50 \mathrm{~g}, 63.46 \mathrm{mmol})$ was suspended in a solution of dry triethyleneglycol $(0.97 \mathrm{~g}, 6.46 \mathrm{mmol})$ in dry DMF $(10 \mathrm{~mL})$. The cooled $\left(-15^{\circ} \mathrm{C}\right)$ suspension was stirred and compound $3(8.24 \mathrm{~g}, 46.13 \mathrm{mmol})$ was added dropwise, under argon gas and exclusion of light. After completion of the addition, stirring was continued for $1 \mathrm{~h}$. Cold acetone (approximately $20 \mathrm{~mL}$ ) was added and the mixture was allowed to warm to ambient temperature. The reaction mixture was then filtered over a short column packed with silica gel. Ethylacetate was used as the eluent. The volatiles were removed from the filtrate and the residue was taken up in toluene. This organic phase was washed with brine and dried $\left(\mathrm{Na}_{2} \mathrm{SO}_{4}\right)$. After filtration and concentration, crude 1 was obtained, which was purified by column chromatography using dichloromethane/ethylacetate $=7: 3$ as the eluent, resulting in a slightly yellowish product $\left(1.17 \mathrm{~g}, 2.24 \mathrm{mmol}, 37 \%, \mathrm{R}_{\mathrm{f}}=0.54\right)$.

${ }^{1} \mathrm{H}$ NMR $\left(\mathrm{CDCl}_{3}\right) \delta 1.93(6 \mathrm{H}, \mathrm{s}, \mathrm{Me}), 3.65\left(4 \mathrm{H}, \mathrm{s}, \mathrm{OCH}_{2} \mathrm{C}_{2} \mathrm{O}\right), 3.72(4 \mathrm{H}, \mathrm{t}$, $\left.\mathrm{CO}_{3} \mathrm{CH}_{2} \mathrm{CH}_{2} \mathrm{O}\right), 3.92\left(4 \mathrm{H}, \mathrm{t}, \mathrm{C}_{2} \mathrm{OCH}_{2} \mathrm{O}\right), 4.29\left(8 \mathrm{H}, \mathrm{m}, \mathrm{CO}_{2} \mathrm{CH}_{2} \mathrm{CH}_{2} \mathrm{OCH}_{2} \mathrm{O}\right.$, $\left.\mathrm{CO}_{3} \mathrm{CH}_{2} \mathrm{CH}_{2} \mathrm{O}\right), 5.31\left(4 \mathrm{H}, \mathrm{S}, \mathrm{OCH}_{2} \mathrm{O}\right), 5.57(2 \mathrm{H}, \mathrm{m}$, olefinic $\mathrm{H}), 6.11(2 \mathrm{H}$, m, olefinic $\mathrm{H})$.

${ }^{13} \mathrm{C} \mathrm{NMR}\left(\mathrm{CDCl}_{3}\right) \delta 166.63,153.95,135.46,125.40,91.66,70.12,68.34,67.77,66.61$, $62.83,17.74$.

FAB-MS calcd for $\mathrm{C}_{22} \mathrm{H}_{35} \mathrm{O}_{14}\left(\mathrm{M}^{+}+\mathrm{H}\right) \mathrm{m} / \mathrm{z}$ 523.5101, found 523.2026, $545.1842(\mathrm{M}+$ $\mathrm{Na})^{+}$.

Ad (ii): All polymeric networks studied in this work are copolymers of NVP and crosslinker 1. A typical preparation method was as follows: NVP, 1 and the photo initiator (2,2 dimethoxy-2-phenyl acetophenone), were weighed into a small flask. The concentration of the photoinitiator was $1: 50$ (mmol initiator : mmol reactive monomer). The mixture was homogenized using an ultrasonic bath. Specimens for the in vitro degradation experiments were prepared in the following manner: Teflon molds containing a circular hole $(\mathrm{d}=8 \mathrm{~mm})$ were filled up with $0.05 \mathrm{~mL}$ of the monomeric mixture. UV Irradiation of the monomeric mixture with a Philips HPA 1000 high power UV light source $(300-400 \mathrm{~nm})$ afforded discs $(\mathrm{d}=8 \mathrm{~mm}$, height $= \pm 1 \mathrm{~mm}$ ). The discs were placed $10 \mathrm{~cm}$ below the light source and were 
then irradiated for $20 \mathrm{~min}$. Specimens for the in vivo experiments (implantation in the rabbit eye) were prepared by injecting the reaction mixture into a Teflon ${ }^{\otimes}$ tube (i.d. $0.8 \mathrm{~mm}$, thin walled). UV Irradiation for $20 \mathrm{~min}, 10 \mathrm{~cm}$ below the lamp then afforded the desired test specimen (2-3 mm).

The different compositions of the monomeric mixtures are summerized in Table 2.1. Materials A - C consist of poly(NVP) crosslinked with the biodegradable monomer. Material D contains only poly(NVP) chains. Materials E - G consist of NVP crosslinked with a non-degradable monomer, tetraethyleneglycol dimethacrylate (compound 2), which is not susceptible to hydrolytic or enzymatic degradation. Materials E - G were prepared for comparative experiments.

Table 2.1: Compositions of Materials $A-G$.

\begin{tabular}{|c|c|}
\hline Material & $\mathbf{1}:$ NVP (molar ratios) \\
\hline A & $1: 10.5$ \\
\hline B & $1: 105$ \\
\hline C & $1: 1000$ \\
\hline D & Poly(NVP) \\
\hline & $\mathbf{2}^{*}:$ NVP (molar ratios) \\
\hline E & $1: 10.5$ \\
\hline F & $1: 105$ \\
\hline G & $1: 1000$ \\
\hline
\end{tabular}

*tetraethyleneglycol dimethacrylate (stable crosslinker)

\subsubsection{Methods}

\section{a) ${ }^{1} \mathrm{H}$ NMR}

${ }^{1} \mathrm{H}$ NMR and ${ }^{13} \mathrm{C}$ NMR spectra were recorded at 399.9 and $100.6 \mathrm{MHz}$, respectively, on a Varian Unity-Plus Spectrometer, using deuterated chloroform as the solvent. Tetramethylsilane was used as the internal standard $(\delta=0.00 \mathrm{ppm})$. 
b) Differential scanning calorimetry (DSC)

DSC measurements were performed on a Perkin Elmer Pyris 1 DSC. Nitrogen was used as the carrier gas. Calibration was performed with gallium and indium. Glasstransition temperatures $(\mathrm{Tg})$ were taken as the midpoint of the transition region. The samples were heated from $20^{\circ} \mathrm{C}$ to $150^{\circ} \mathrm{C}$ at a heating rate of $5 \mathrm{deg} . / \mathrm{min}$.

\section{c) Fast Atom Bombardment mass spectrometry (FAB-MS)}

FAB-MS was carried out using a JEOL JMS SX/SX102A four-sector mass spectrometer, coupled to a JEOL MS/MP7000 data system. The samples were loaded in a matrix solution (glycerol, thioglycerol of nitrobenzylalcohol) onto a stainless steel probe and bombarded with xenon atoms with an energy of $3 \mathrm{keV}$. During the high resolution FAB-MS measurements a resolving power of 10,000 $(10 \%$ valley definition) was used. Cesiumiodide, glycerol or polyethylene oxide $\left(\mathrm{M}_{\mathrm{W}, \mathrm{av}}=600\right)$ was used to calibrate the mass spectrometer.

d) Matrix Assisted Laser Desorption Ionisation (MALDI) time-of-flight (TOF) mass spectrometry

MALDI-TOF was carried out using a PerSeptive Biosystems Voyager-DE-RP MALDI-TOF mass spectrometer. A $337 \mathrm{~nm}$ UV nitrogen laser producing $3 \mathrm{~ns}$ pulses was used in the reflectron mode. The samples were prepared by mixing $10 \mu \mathrm{l}$ of a $50 \%$ acetonitrile/water solution of the sample with $20 \mathrm{~mL}$ of a solution of $3 \mathrm{mg} / \mathrm{L}$ $\alpha$-cyano-4-hydroxy cinnamic acid in water, $1 \mathrm{~mL}$ of that solution was loaded on the gold-sample plate.

\section{e) In vitro swelling and degradation of specimens}

The dry weights of a series of discs A - G (approximately 30 for each composition) were measured, and the discs were incubated individually at $37^{\circ} \mathrm{C}$ in plastic vials containing phosphate buffered saline (PBS, $\mathrm{pH}=7.4,4 \mathrm{~mL}$ ). The medium was exchanged weekly. At regular time intervals, discs were taken out, washed, freezedried, and re-weighed. Initially 6 discs were removed simultaneously. It appeared 
that the loss of mass could be determined without a large experimental error. Then it was decided to use only three discs at a time.

\section{f) In vivo swelling and degradation of specimens}

Ten pigmented rabbits of both genders in the weight range of $3-3.5 \mathrm{~kg}$, were used exclusively for these experiments, according to the protocols approved by the Experimental Animal Committee of the University of Maastricht. The animals were cared for according to the "Guide for the Care and Use of Laboratory Animals", as published by the National Institutes of Health (NIH publication no. 85-23, revised 1985). All animal experiments were performed under sterile conditions. Ethylene oxide was used to sterilize the equipment necessary for the implantation, including the polymeric test specimen. The hollow needles used for the implantation are 5.9 $\mathrm{cm}$ long with an internal diameter of $0.8 \mathrm{~mm}$ and an external diameter of $1 \mathrm{~mm}$. The in vivo behavior of materials $A-G$ in the vitreous (biocompatibility, swelling and degradation) was studied with 10 rabbits (19 eyes in total, Table 2.2). Implantation of the dry cylindrical specimens (dimensions: length 2-3 mm, 
Table 2.2: Experimental Set-Up of the In Vivo Experiments with Materials A - G. R: Right eye; L: Left eye.

\begin{tabular}{|c|c|c|c|c|c|c|c|}
\hline \multirow[t]{2}{*}{ Rabbit } & \multicolumn{7}{|c|}{ Materials } \\
\hline & A & B & C & $\mathrm{D}$ & $\mathrm{E}$ & $\mathrm{F}$ & G \\
\hline $1^{1}$ & $\mathrm{R}$ & & & & & & \\
\hline 2 & $\mathrm{~L}, \mathrm{R}$ & & & & & & \\
\hline 3 & $\mathrm{~L}, \mathrm{R}$ & & & & & & \\
\hline $4^{2}$ & & $\mathrm{~L}$ & $\mathrm{R}$ & & & & \\
\hline 5 & & $\mathrm{~L}, \mathrm{R}$ & & & & & \\
\hline 6 & & $\mathrm{~L}, \mathrm{R}$ & & & & & \\
\hline 7 & & & $\mathrm{~L}, \mathrm{R}$ & & & & \\
\hline 8 & & & $\mathrm{~L}, \mathrm{R}$ & & & & \\
\hline $9^{3}$ & & & & L & $\mathrm{R}$ & & \\
\hline $10^{3}$ & & & & & & L & $\mathrm{R}$ \\
\hline
\end{tabular}

${ }^{1}$ This rabbit died unexpectedly 9 weeks post implantation, probably because of pneumonia; ${ }^{2}$ This animal was sacrificed 34 weeks post implantation; ${ }^{3}$ These animals were sacrificed approximately 9 months post implantation.

diameter $0.8 \mathrm{~mm}$ ) proceeded as follows: an incision was made in the pars plana of the rabbit eye with a sclerostomy knife. The test specimen was placed in a hollow needle. The needle was inserted gently into the vitreous at the incision point. A combination of phenylephrine (5\%) and tropicamine ( $0.5 \%$ ) was used to widen the pupils in order to monitor the implantation of each specimen. All eyes were treated with chloramphenicol $(1 \%)$, containing vitamin $A$ for 5 days after the implantation. Enucleated eyes were immediately fixed in formalin solution (10\%) and routinely embedded in paraffin. Serial $5 \mu \mathrm{m}$ sections were cut of the entire eye, and stained with hematoxilin and eosin. The samples were examined by an experienced ophthalmopathologist. 


\section{$2.3 \quad$ Results}

\subsubsection{Physico-chemical characterization of materials A - G}

DSC experiments were performed for materials $\mathrm{A}-\mathrm{C}$ in the temperature range $20-$ $150^{\circ} \mathrm{C}$, at a heating rate of $5 \mathrm{deg}(\mathrm{C})$ per min. No clear glass transitions could be measured. Fourier transform infrared spectroscopy of materials $A-G$ resulted in typical spectra, which, however, provided no qualitative or quantitative information about the presence or absence of residual free monomers in these materials. For this reason we decided to perform a series of NMR experiments in order to check the conversion of the photopolymerization reactions. Specimens of materials A, B, and C (approximately $70 \mathrm{mg}$ each) were immersed in $1.00 \mathrm{~mL}$ of a $\mathrm{Ca}(\mathrm{OH})_{2}$ with $\mathrm{pH}=12$, at $20^{\circ} \mathrm{C}$ in closed vials. The vials were stored for 10 weeks, during which swelling and partial degradation was clearly observed. Samples of the supernatant $(100 \mu \mathrm{L})$ were mixed with $\mathrm{D}_{2} \mathrm{O}(500 \mu \mathrm{L})$, and ${ }^{1} \mathrm{H}$ NMR spectra were measured. No free NVP could be detected (NVP has a very characteristic NMR resonance at $\delta 6.7-6.9 \mathrm{ppm}$ ), while the spectra clearly showed the presence of dissolved oligo(NVP) and/or poly(NVP). We can conclude from this that the conversion of the photopolymerization reaction is higher than approximately $98 \%$. 


\subsubsection{Swelling and degradation in vitro}

Material A was found to change color from transparent to white-opaque within

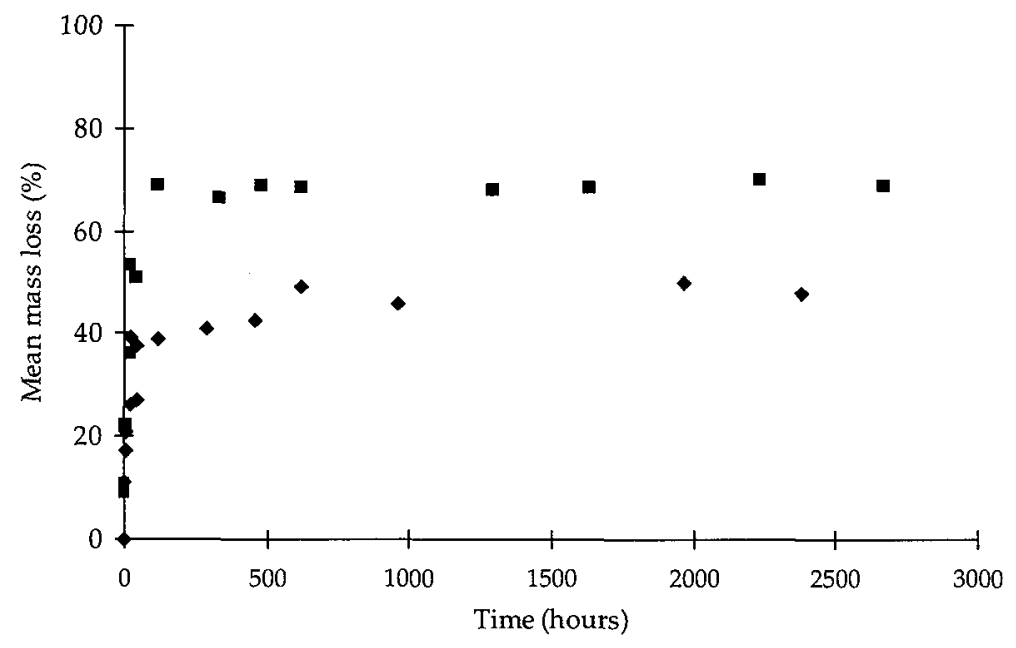

Figure 2.2: Mean loss of mass, measured for materials $A$ ( $\mathbf{\square})$ and $E(\bullet)$ as a function of time.

several hours after incubation in vitro. In the course of the first week, the discs turned transparent again. Furthermore, swelling and partial dissolution of the material was clearly observed in the first week. Afterwards, a stable situation was achieved, during which the remnants of the polymeric discs did not change their size or appearance. Material B showed much faster swelling and degradation: these discs were seen to dissolve within approximately 1 day. Materials $C$ and $D$ dissolved almost immediately after incubation. The behavior of material $\mathrm{E}$ closely resembled that of material $A$; material $F$ behaved like material $B$, and $G$ resembled $\mathrm{C}$ and D. Noteworthy, materials $\mathrm{A}$ and $\mathrm{E}$ showed comparable behavior within the time-frame of our experiments, although the loss of mass was significantly higher For A. Figure 2.2 shows the loss of mass measured for materials $A$ and $E$ (incubated 
in PBS buffer at $37^{\circ} \mathrm{C}$ ), as a function of time. Our explanation for this observation is that materials $A$ and $E$ both release extractables, i.e., oligo(NVP) and/or poly(NVP) molecules which are not crosslinked. We hypothesized that for material A scission of the carbonate bonds in the crosslinker further contributes to the loss of mass. In order to check this hypothesis, we studied the swelling/degradation of materials A and $\mathrm{E}$ in de-aired PBS buffer. After 2 days, a clear difference between materials $\mathrm{A}$ and $\mathrm{E}$ was observed: small gas bubbles (presumably carbondioxide) were seen to evolve at the surface of the material A specimen, whereas no gas evolution was noted for material $\mathrm{E}$. This observation strongly supports the idea that material $\mathrm{A}$ swells, loses extractables, and decomposes via hydrolysis of the carbonate bonds in its crosslinks, whereas the more stable material E merely shows swelling and dissolution of extractables.

\subsubsection{In vivo behavior of materials $\mathrm{A}-\mathrm{G}$ in the vitreous body of the rabbit eye}

Cylindrical specimens of materials A - G were implanted in the vitreous body of rabbit eyes, as described above. In most cases, the implants could be observed directly through the lens. Photographs of the implants were taken at regular time intervals, using a fundus camera. Rabbits \# 1,2 and 3, which had material A implanted in one (\#1) or two ( $\# 2$ and 3 ) eyes, show a consistent picture; the specimens of material A did not swell, and did not invoke any adverse effects, such as inflammation, irritation, or even encapsulation. Figure 2.3 shows the rod of material $\mathrm{A}$ in the right eye of rabbit \#1, at days 1,27, and 61 post implantation. Clearly, no swelling has occurred. Rabbit \#1 died unexpectedly after 9 weeks post implantation, probably because of pneumonia. The right eye was enucleated and studied both macroscopically and microscopically. The pars plana opening was marked with blue ink, and a small polymeric object was noted macroscopically. No cellular reaction was seen. Microscopic evaluations showed remnants of a bifringent material which, however, was largely dissolved during the 
manipulations which were necessary to prepare the serial $5 \mu \mathrm{m}$ sections. Most interestingly, there was absolutely no cellular reaction to the implant. Rabbits \# 2 and 3 were not sacrificed, since they will be used for long-term studies on the intraocular behavior of material A. Rabbits \# 4-6, which had material B implanted in one (\#4) or two (\#5 and 6) eyes, showed a markedly different picture. Figure 2.4 shows the rod of material $B$ in the left eye of rabbit \#4, at days 4, 28,67, and 137 post implantation. Simultaneous swelling and dissolution/degradation of the polymer is noted. Rabbit \#4 was sacrificed 34 weeks post implantation. The enucleated left eye (containing polymer B) was marked macroscopically with blue ink in the pars plana opening. The presence of the polymeric material, adherent to the lens, was established unequivocally, see Figure 2.5 . The lens shows cataract caused by the contact with the polymeric object. 

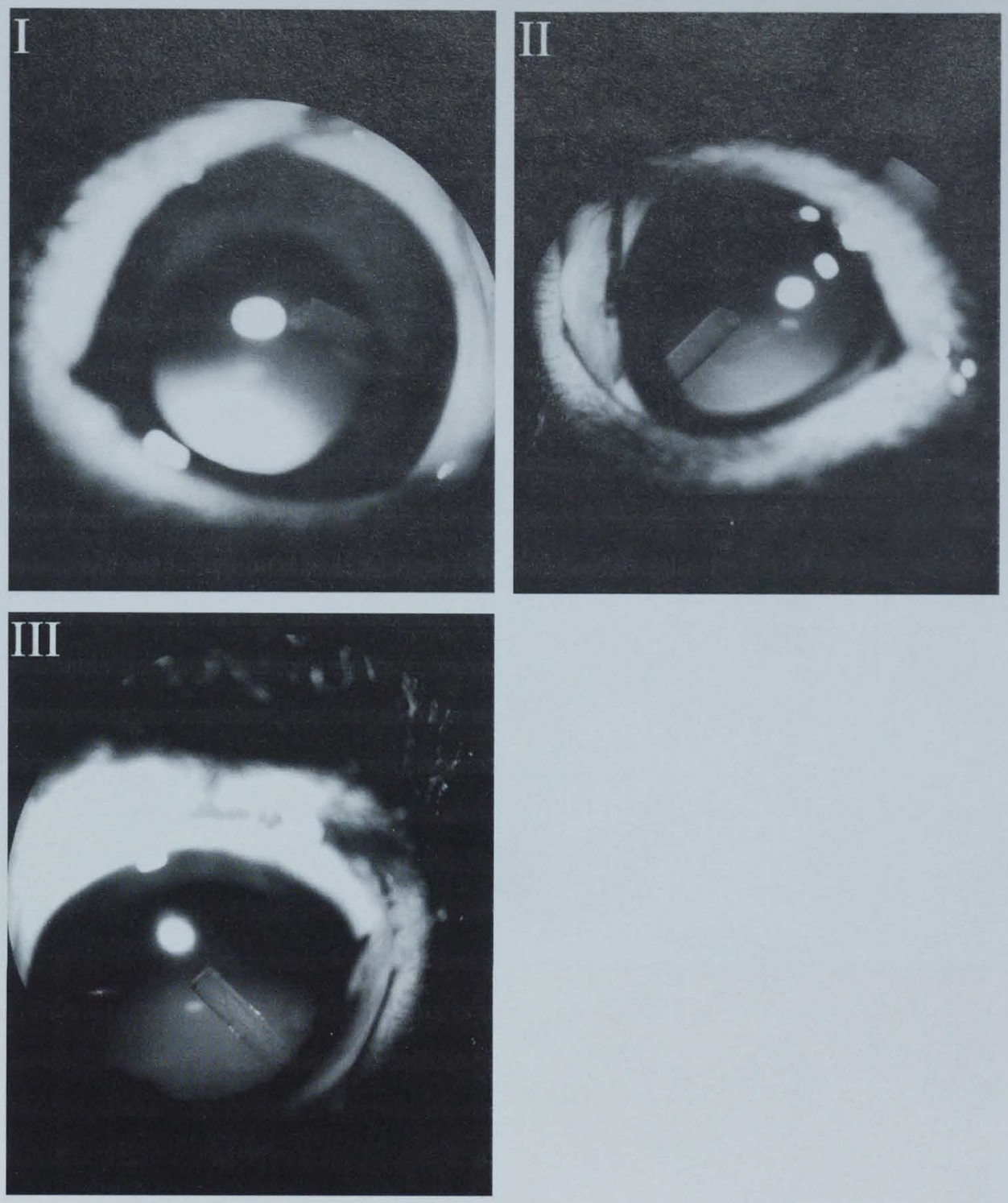

Figure 2.3: Cylindrical specimen of material $A$ in the right eye of rabbit \#1. I: 1 day post implantation (p.i.); II: 27 days p.i.; III: 65 days p.i. 

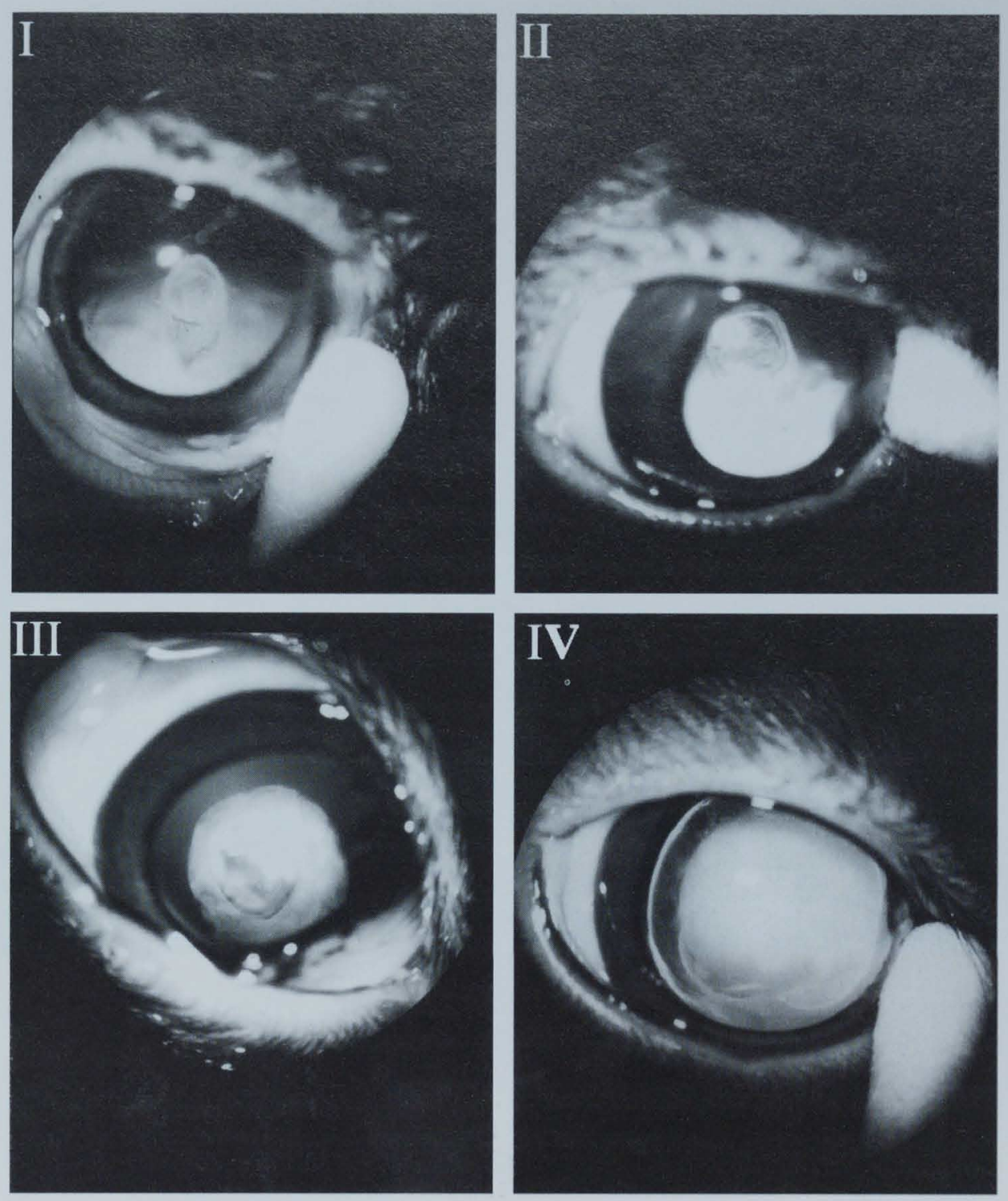

Figure 2.4: Cylindrical specimen of material B in the left eye of rabbit \#4. I: 4 days p.i.; II: 28 days p.i.; III: 67 days p.i.; IV: 137 days p.i. Note the occurrence of cataract after extensive swelling of the specimen (IV). 

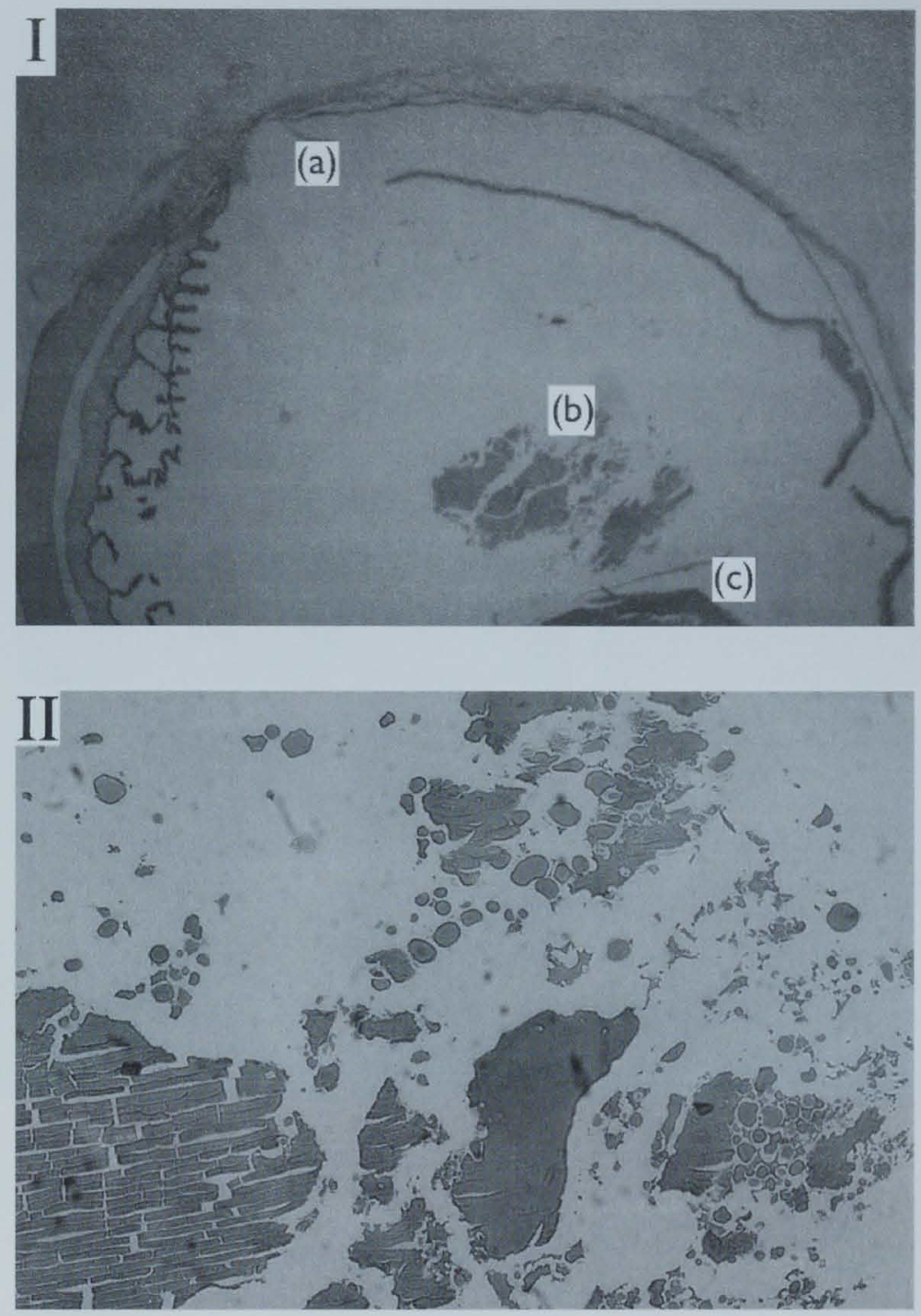

Figure 2.5: Microscopic view of the left eye of rabbit \#4, containing material B as an implant in the vitreous body (sacrificed after 34 weeks). I: overview of the eye, showing the pars plana opening (a), the partially degraded material $B(b)$, and a part of the lens (c). II: detailed view of the partially degraded material $B$. No adverse cellular reactions are seen.

Unfortunately, cutting of the eye tissue, which was routinely embedded in paraffin, caused dislocation of the lens. Most probably, this problem can be avoided through 
embedding in hard plastic. No cellular reaction to the polymer or the breakdown products is found. Rabbits \# 5 and 6 were not sacrificed (vide supra). The enucleated right eye (in which polymer $C$ had been implanted) was treated analogously. Some erythrocytes are found in the vitreous, pointing out that a minor bleeding occurred in the vitreous, probably due to the implantation procedure. No remnants of the polymeric material could be detected. We decided not to sacrifice rabbits \# 7 and 8, but to use these animals (like rabbits \# 2,3,5 and 6) for studies on the long term biocompatibility in the vitreous body.

Material D (rabbit \#9, left eye) again showed fast swelling and dissolution. Already within 2 days, these specimens looked fragmented, gel-like and white-opaque. No remnants of the polymer could be detected about 2 months later. Material E (rabbit \#9, right eye) closely resembles $A$. The behavior of materials $F$ and $G$ was difficult to assess, since these specimens remained transparent, which hampered their optical localization.

\subsection{Discussion}

Materials A - C represent a new class of biodegradable biomaterials. These materials are novel in two respects:

- the materials consist of poly(NVP) chains, which are crosslinked by molecule $\mathbf{1}$, which is susceptible to hydrolytic scission. This implies that the materials undergo a change from crosslinked to free macromolecular chains (or, alternatively stated, from insoluble to soluble), in the course of the degradation process.

- degradation leads to the formation of carbondioxide and alcohols, which implies that the breakdown products do not exert any catalytic effect on the hydrolysis at other sites within the biomaterial. This aspect marks a significant difference with respect to well-known biodegradable poly(esters), such as poly(lactic acid), copolymers of lactic acid and glycolic acid, and poly( $\beta$-hydroxyesters) such as poly(hydroxybutyrate). Degradation of the latter materials leads to the 
formation of carboxylic acids, which do catalyze further breakdown of the material. Consequently, these poly(esters) frequently show a "burst-effect" during the degradation, which is highly undesirable with respect to applications in the drug delivery field.

The experimental data obtained with materials A - C show that kinetic data on the degradation in vitro can not be used to predict the degradation in vivo. Breakdown of materials A - $\mathrm{C}$ in vitro is much faster than in the vitreous body of the rabbit eye. This can probably be ascribed to the facts that the vitreous body has a higher viscosity and a lower $\mathrm{pH}$, compared to the PBS buffer. The experimental data show that it is possible to influence the kinetics of the degradation via the crosslink density. Increasing the crosslink density slows down both swelling and degradation.

The in vitro behavior of material $\mathrm{A}$ and the control material $\mathrm{E}$ requires some further comment. It was observed (Figure 2.2) that material A dissolves/degrades for approximately $70 \%$ during the first week. Afterwards, a stable situation is achieved, during which no further loss of mass could be detected. Our tentative explanation for these observations is that the crosslinks may be distributed unevenly over the material sample, as the relative reactivity ratios of NVP and methacrylates are known to be markedly different. In other words: there is no random copolymerization during the formation of the network. The crosslinker is expected to react before NVP starts to participate in the reaction. Under these circumstances, regions of highly crosslinked material (resistant to swelling and degradation) are formed, and other regions are essentially non-crosslinked NVP (extractable). Obviously, this effect is only of marginal importance in materials $B$ and $C$, for which the crosslink density is much lower. Note, however, that materials $\mathrm{A}$ and $\mathrm{E}$ show a clear difference with respect to the degradation in vitro; this difference is clearly consistent with the occurrence of hydrolytic scission of the carbonate bonds present in material $\mathrm{A}$, but not in $\mathrm{E}$.

In this study, relatively large cylindrical specimens of polymers $\mathrm{A}-\mathrm{C}$ were used for the in vivo experiments (dimensions: length: $2-3 \mathrm{~mm}$, diameter: $0.8 \mathrm{~mm}$ ). For those materials which show extensive swelling (i.e., materials B and C), this is associated 
with a significant risk for cataract formation. In general, contact of objects to the lens causes cataract. This may explain why, in this study, cataract is found for material B, and not for material A (compare: Figures 2.3 and 2.4).

\subsection{Concluding Remarks}

Materials A - C are potentially useful as carriers for drug delivery in the vitreous body of the eye. Experiments in vitro and in vivo revealed smooth and reproducible swelling and degradation in the absence of a burst-effect. The kinetics of the simultaneous swelling and degradation processes can be controlled via synthesis. Implantation of these materials did not cause any harmful bio-incompatibility effects, such as inflammation, irritation or infection. It is clear that these materials can not be used in the cylindrical form, which was used in the in vivo experiments reported here (dimensions: length 2-3 mm, diameter $0.8 \mathrm{~mm}$ ). Swelling of such large objects is associated with a significant risk for cataract formation, as was observed with material B. Most likely, the use of much smaller microspheres, impregnated with, for instance, ganciclovir, will help to avoid these problems.

\subsection{References}

1. Henry, K.; Cantrill, H.; Fletcher, C.; Chinnock, B.J.; Balfour, H.J. An. J. Ophthalmol. 1987, $103,17$.

2. Cantrill, H.L.; Henry, K.; Melroe, N.H.; Knobloch, W.H.; Ramsay, R.C.; Balfour, H. Jr. Ophthalmol. 1989, 96, 367 .

3. Cochereau, M.I.; Lehoang, P.; Lautier, F.M.; Zazoun, L.; Marcel, P.; Robinet, M.; Matheron, S.; Katlama, C.; Gharakhanian, S.; Rozenbaum, W. Ophthalnol. 1991, 98, 1348.

4. Martin, D.F.; Parks, D.J.; Mellow, S.D.; Ferris, F.L.; Walton, R.C.; Remaley, N.A.; Chew, E.Y.; Ashton, P.; Davis, M.D.; Nussenblatt R.B. Arch. Ophthalmol. 1994, 112, 1531.

5. Anand, R.; Nightingale, S.D.; Fish, R.H.; Smith, T.J.; Ashton, P. Arch. Ophthalmol. 1993, 111, 223.

6. Kunou, N.; Ogura, Y.; Hashizoe, M.; Honda, Y.; Hyon, S.H.; Ikada, Y. I. Control. Release 1995, 37, 143.

7. Hashizoe, M.; Ogura, Y.; Takanashi, T.; Kunou, N.; Honda, Y.; Ikada, Y. Current Eye Res. 1997, 16, 633. 
8. Kimura, H.; Ogura, Y.; Hashizoe, M.; Nishiwaki, N.; Honda, Y.; Ikada, Y. Invest. Ophthalmol. Vis. Sci. 1994, 35, 2815.

9. Veloso, A.A.S.; Herrero-Vanrell, R.; Refojo, M.F. Invest. Ophthalnol. Vis. Sci. 1997, 38, 665.

10. Moriteira, T.; Ogura, Y.; Honda, Y.; Wada, R.; Hyon, S.; Ikada, Y. Invest. Ophthalmol. Vis. Sci. 1991, 32, 1785.

11. Khoobehi, B.; Stradtman, M.O.; Peyman, G.A.; Aly, O.M. Ophthalmic Surg. 1991, 22, 175.

12. Peyman, G.A.; Conway, M.; Khoobehi, B.; Soike, K. Int. Ophthalmol. 1992, 16, 109.

13. Giordano, G.G.; Chevez-Barrios, P.; Refojo, M.; Garcia, C.A. Current Eye Res. 1995, 14, 761.

14. Hong, Y.; Chirila, T.V.; Cuypers, M.J.H.; Constable, I.J. J. Biomaterials Appl. 1996, 11, 135.

15. Hong, Y.; Chirila, T.V.; Vijayasekaran, S.; Shen, W.; Lou, X.; Dalton, P.D. J. Biomed. Mater. Res. $1998,41,650$.

16. Chirila, T.V.; Constable, I.J.; Hong, Y.; Vijayasekaran, S.; Humphrey, M.F.; Dalton, P.D.; Tahija, S.G.; Maley, M.A.L.; Cuypers, M.J.H.; Sharp, C.; Moore, S.R.; Davies, M.J. Cells Mater. 1995, 5, 83.

17. Hong, Y.; Chirila, T.V.; Vijayasekaran, S.; Davies, M.J.; Maley, M.A.L. In Vitro Toxicol. 1996, 9, 73.

18. Vijayasekaran, S.; Chirila, T.V.; Hong, Y.; Tahija, S.G.; Dalton, P.; Constable, I.J.; McAllister, I.L. J. Biomater. Sci., Polymer Ed. 1996, 7,685.

19. Hong, Y.; Chirila, T.V.; Vijayasekaran, S.; Dalton, P.D.; Tahija, S.G.; Cuijpers, M.J.H.; Constable, I.J. J. Biomed. Mater. Res. 1996, 30, 441.

20. Teranishi, K.; Nakao, H.; Komoda, A.; Hisamatsu, M.; Yamada, T. Synthesis 1995, 176. 


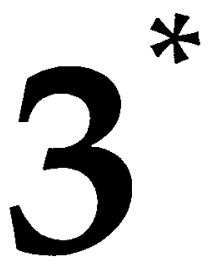

\section{Biodegradable Three-Dimensional}

Networks of Poly(dimethylaminoethyl methacrylate). Synthesis,

Characterization and In vitro Studies of Structural Degradation and Cytotoxicity 


\section{Summary}

In ophthalmology, there is a need for novel degradable biomaterials for e.g. controlled drug release in the vitreous body. These degradable materials should feature both excellent biocompatibility, and well-defined kinetics of degradation. In most cases, poly(D,L-lactic acid), or poly(lactic-co-glycolic acid) are used. These materials, however, suffer from some serious drawbacks, since the degradation kinetics are difficult to control, especially since so-called "burst-degradation" occurs. Here, a set of novel polymeric networks which largely consist of poly(dimethylaminoethyl methacrylate) (poly(DMAEMA)) are described; these materials are crosslinked via a dimethacrylate molecule that contains two carbonate groups. This system is susceptible to hydrolytic scission. The degradation products do not exert a catalytic effect on the ongoing degradation reaction (i.e. there is no burst-effect). The synthesis of three of these materials, which differ merely with regard to the crosslinker content is described in this chapter. These materials were characterized through DMTA, 'H NMR and FT-IR spectroscopy, and scanning electron microscopy. The reaction DMAEMA + 2-hydroxyethyl methacrylate (HEMA) was studied in detail, using 'H NMR spectroscopy, and these experiments revealed that the reaction of DMAEMA and HEMA produces a random (Bernouillian-type) copolymer. From this, we contend that the new materials have more or less uniform distribution of the crosslinks throughout their volume. Structural degradation of the three materials was studied in vitro, at $\mathrm{pH} 7.4,9.1$ and 12.0. It is found that the materials feature smooth structural degradation, which can be controlled, as was expected via the crosslink density and the $\mathrm{pH}$. Subsequently in vitro studies on the biocompatibility of these materials were performed. The MTT cytotoxicity assay revealed that the materials were cytotoxic to chondrosarcoma cells. This is most probably due to local increase of the $\mathrm{pH}$ due to the basic character of the pending dimethylamino groups, while leaching of free DMAEMA monomers could also play a role. Cytotoxicity was also seen in cell cultures (human fibroblasts isolated from donor corneas) which were grown in contact with the materials. It is 
concluded that the new materials have attractive degradation characteristics, but that their cytotoxicity makes them unsuitable for applications in ophthalmology.

\subsection{Introduction}

Polymerization of 1-vinyl-2-pyrrolidinone (NVP) produces hydrophilic materials, which generally possess excellent biocompatibility. Poly(NVP) is found in numerous pharmaceutical and cosmetic preparations. ${ }^{1-3}$ We have shown recently, that NVP can also be used to produce biodegradable polymeric biomaterials. ${ }^{+}$ These materials are three-dimensional networks of poly(NVP), while the crosslinks (1) contain two hydrolytically labile carbonate groups. These materials are designed in such a way that hydrolysis of a carbonate bond occurs without local change of the $\mathrm{pH}$, since merely two alcohols and $\mathrm{CO}_{2}$ are generated.<smiles>C=C(C)C(=O)OCCOCCOC(=O)OCCOCCOCCOC(=O)OCOCCOC(=O)C(=C)C</smiles>

Therefore, the degradation of these novel materials is not catalyzed by the degradation products (as is the case for -for instance- poly(D,L-lactic acid) or poly(lactic-co-glycolic acid)). ${ }^{5,6}$ The new materials show simultaneous swelling and degradation. This implies that the kinetics of degradation are governed by, inter alia, the chemical stability of the crosslinks, and by the swelling behavior of the material. The content of crosslinks determines the swelling behavior. Two extreme cases can be distinguished:

- Swelling is the rate-determining step in the process. This means that the degradation will proceed according to the surface-erosion model.

- Hydrolysis is the rate-determining step in the process. In this case, the material will absorb water until equilibrium conditions are reached, and hydrolysis of most of the crosslinks will occur thereafter throughout the entire volume of the material (bulk erosion) ${ }^{?}$ 
It is of interest to note that the degradation of these materials results in the liberation of poly(NVP) and/or oligo(NVP) linear polymers. We envisage application of these materials for controlled drug delivery in the vitreous body of the eye. ${ }^{9.12}$ Hong et al. and Vijayasekaran et al., who work on poly(NVP) hydrogels as vitreous substitutes, found granular material, probably poly(NVP) and oligo(NVP) in the intercellular spaces of the neural retina, in macrophages, and in the retinal pigment epithelium cells, ${ }^{1,-15}$ Fragmentation and phagocytosis of the synthetic gels was assumed.

In our previous work it was established that the degradation kinetics were indeed related to the crosslink density and that these materials were highly biocompatible in the vitreous body of rabbit eyes. ${ }^{4}$ But it was also found that the combination of NVP and crosslinker 1 was not optimal. The reactivity of NVP and methacrylates is different, and, therefore, the resulting crosslinked materials were not entirely homogeneous. Most likely, the crosslinks do take part in the polymerization reaction much faster than the NVP molcules. This has several consequences: (i), the crosslinks are unevenly distributed over the bulk of the material; (ii), the material consists of highly crosslinked regions which are resistant to swelling and degradation; (iii), the regions of high crosslink density are separated by regions of low crosslink density; these consist of linear poly(NVP) and oligo(NVP) chains. The latter molecules are "extractables", i.e. they can readily escape from the bulk of the material upon its immersion in aqueous buffer. Lindemann et al. described similar inhomogeneity for hydrogels consisting of polyacrylamide crosslinked with different types and concentrations of crosslinkers. ${ }^{16}$ Despite the good biocompatibility of these materials, we concluded from these observations, that the degradable system needs adjustment in order to be suitable as a biodegradable matrix for e.g. controllable intra-ocular drug delivery.

A series of analogous materials, using a methacrylate-type hydrophilic monomer, instead of NVP were prepared and investigated. It was expected that the copolymerization reaction with crosslinker $\mathbf{1}$ would then result in a more random-like (Bernouillian-type) copolymer, thus avoiding the drawbacks that 
were seen with the NVP-based materials in our first study. A study on a series of hydrophilic biodegradable networks, which are composed of DMAEMA, and crosslinker 1 are described in this chapter. We describe: (i), synthesis of four materials (A - D) which differ with respect to the crosslink density; (ii), ${ }^{1} \mathrm{H}$ NMR experiments which reveal that copolymerization of DMAEMA and 2hydroxyethyl methacrylate (HEMA) produces random-type copolymers; (iii), FTIR and 'H NMR measurements which were conducted to determine the free monomer content; (iv), dynamic mechanical thermal analysis of materials $\mathrm{A}-\mathrm{C}$; (v), scanning electron microscopy images of materials $\mathrm{A}-\mathrm{C}$ before and after incubation in buffer solution; (vi), studies on the kinetics of degradation of materials A-C in vitro; and (vii), the biocompatibility of these materials, tested with the MTT test and in a culture system of human corneal fibroblasts and epithelial cells.

\subsection{Experimental section}

\subsubsection{Materials}

\section{a) Chemicals}

All solvents and starting reagents were of the highest available purity or were purified as specified. Commercial DMAEMA was distilled under reduced pressure, in batches of approximately $500 \mathrm{~mL}$; preruns of approximately $50 \mathrm{~mL}$ were discarded. The main fractions were collected and stored at $-18{ }^{\circ} \mathrm{C}$. The buffer solutions (phosphate-buffered saline (PBS; pH 7.4), borax ( $\mathrm{pH}$ 9.1), and a saturated calcium hydroxide solution; $\mathrm{pH}$ 12.0) were made immediately prior to use, via standard procedures.

\section{b) Preparation of biodegradable materials}

These preparations comprised two steps: (i), synthesis of the bifunctional monomer $\mathbf{1}$, which was described previously ${ }^{4}$; and (ii), the photo-copolymerization of $\mathbf{1}$ with 
DMAEMA. A typical preparation started with weighing approximately 10 grams of the reactive monomers DMAEMA and 1 in the desired ratio. The photoinitiator (2,2-dimethoxy-2-phenyl acetophenone) was added to this mixture, such that the molar ratio of molecules photoinitiator : methacrylate groups was $1: 50$. The mixture was then flushed with argon gas and homogenized through ultrasonic agitation. The polymerization was carried out in a PTFE mould. The samples for DMTA analysis were prepared in a PTFE mould ( $\mathrm{h}=2 \mathrm{~mm}, \mathrm{l}=30 \mathrm{~mm}, \mathrm{w}=15 \mathrm{~mm}$ ). The samples for other experiments were prepared in a mould, which consists of a PTFE tube (diameter $=8 \mathrm{~mm}$, length is $1.5 \mathrm{~cm}$ ), which is tightly fitted onto a PTFE stopper on one end. The cavities were filled with the homogenized reaction mixture $(0.05 \mathrm{~mL})$, and the mould was then irradiated with a Philips HPA 1000 high-power ultraviolet light source; the distance from the lamp to the mould was $10 \mathrm{~cm}$. The mould was taken away from the lamp after $20 \mathrm{~min}$ irradiation. The polymerized discs were carefully removed, turned upside down, and replaced in their cavities. Irradiation was then repeated for another $20 \mathrm{~min}$. Four different materials were made in this manner: material A (molar ratio DMAEMA : $1=100: 1$ ), material $\mathrm{B}$ (molar ratio DMAEMA : $1=500: 1$ ), material $\mathrm{C}$ (molar ratio DMAEMA : $1=1000$ : 1), material D (poly(DMAEMA).

\subsubsection{Physico-chemical analysis of the polymeric materials}

\section{a) Apparatus}

${ }^{1} \mathrm{H}$ NMR and ${ }^{13} \mathrm{C}$ NMR spectra were recorded at 399.9 and $100.6 \mathrm{MHz}$, respectively, on a Varian Unity-Plus NMR spectrometer with variable temperature facilities. $\mathrm{CDCl}_{3}$ or $\left(\mathrm{CD}_{3}\right)_{2} \mathrm{SO}$ were used as solvents. Tetramethylsilane was used as the internal standard $(\delta=0.00 \mathrm{ppm})$. Fourier-transform infrared measurements were performed on a Biorad FTS 60 equipped with an interferometer as detector. The spectra were obtained after accumulation of 16 scans between 4000 and $600 \mathrm{~cm}^{-1}$.

Dynamic mechanical thermal analyses were conducted in the tensile mode on a DMTA MKIII instrument (Polymer Laboratories). The polymeric rods were 
machined into rectangular plates (approximately $19 \times 3 \times 1.4 \mathrm{~mm}$ ), and were measured at a frequency of $1 \mathrm{~Hz}$, a static force of $0.1 \mathrm{~N}$ (dynamic strain $=16 \mu \mathrm{m}$ ), and a heating rate of $2{ }^{\circ} \mathrm{C} / \mathrm{min}$. The samples were run from -20 to $80^{\circ} \mathrm{C}$.

SEM analysis of the polymeric surfaces was performed on a R.J. Lee PSEM75 operating at an accelerating voltage of $15 \mathrm{kV}$. All samples were freeze-dried and sputter coated with gold prior to scanning.

\section{b) Experiments on the reactivity of DMAEMA and NVP vs. HEMA}

These experiments were based on detailed monitoring of the copolymerization reaction DMAEMA + HEMA, starting from a monomer mixture with a $1: 1$ molar ratio, and using AIBN (0.2 mol \%) as the radical initiator. The DMAEMA + HEMA + AIBN mixture $(0.05 \mathrm{~mL})$ was dissolved in $\left(\mathrm{CD}_{3}\right)_{2} \mathrm{SO}(0.6 \mathrm{~mL})$, and transferred into a 5-mm NMR sample tube. The tube was placed inside the cavity of the NMR spectrometer, and the reaction was run at $75^{\circ} \mathrm{C}$. After every 200 seconds a spectrum was stored. ${ }^{17}$ The copolymerization was monitored up to a conversion of approximately $36 \%$. The conversion based on reacted DMAEMA and reacted HEMA can be calculated at the different time points with the following equation:

$$
\begin{array}{rlll}
\text { Conversion } & = & \left((2 / 3) * I_{m}\right) /\left(\left((2 / 3) * I_{m}\right)+I_{v}\right) * 100 \% \\
I_{m} & = & \text { integral of pendant methyl groups }(\delta 0.7-1.3 \mathrm{ppm}) \\
I_{0} & =\quad \begin{array}{l}
\text { integral of olefinic protons of unreacted HEMA and } \\
\end{array} & \text { unreacted DMAEMA }(\delta 5.5-6.1 \mathrm{ppm})
\end{array}
$$

Figure 3.1 (Results and discussion) shows the relevant expansions of the ${ }^{1} \mathrm{H}$ NMR spectra, recorded at the start of the reaction, and at a conversion of approximately $36 \%$.

A similar experiment was conducted with NVP instead of DMAEMA, in order to compare the reactivity of HEMA versus NVP and the reactivity of HEMA versus DMAEMA. The conversion based on NVP and HEMA was calculated in the following manner: 


$$
\begin{aligned}
& \text { Conversion }=\left(\left(I_{N}+I_{H}\right)_{t=0}-\left(I_{N}+I_{H}\right)_{t=x}\right) /\left(I_{N}+I_{H}\right)_{t=0} \\
& I_{N} \quad=\quad \text { integral unreacted NVP }(\delta 6.8-7.0 \mathrm{ppm}) \\
& I_{H}=\quad \text { integral unreacted HEMA }(\delta 5.5-6.1 \mathrm{ppm}) \\
& \mathrm{t}=0 \text { at the start of the polymerization } \\
& \mathrm{t}=\mathrm{x} \text { during the polymerization }
\end{aligned}
$$

\section{c) In vitro degradation and swelling}

The dry weights of a series of discs of materials A - D (approximately 135 of each composition) were measured, and the discs were incubated individually at $37^{\circ} \mathrm{C}$ in plastic vials $(4 \mathrm{~mL})$, containing a buffer solution. Three different buffers were used (see Materials). In each sample, the medium was exchanged weekly. Discs were removed at regular time intervals, washed, lyophilized, and re-weighed. The loss of mass was used as a measure for the degradation. Initially, 6 discs were removed per time-point; further in the experiment only 3 discs were taken simultaneously.

\subsubsection{Cytotoxicity and biocompatibility of the polymeric materials}

\section{a) MTT assay}

Samples (a quarter of a circular disc (diameter $8 \mathrm{~mm}$, height $0.5 \mathrm{~mm}$ )) of materials A, $C$ and $D(n=2)$ were sterilized with $70 \%$ ethanol and subsequently rinsed three times with sterile PBS. Human chondrosarcoma cells (SW1353) were inoculated in a 24-wells tissue culture polystyrene (TCP) at a density of approximately $10^{4}$ cells/well in culture medium $(500 \mu \mathrm{L})$. Culture medium was Dulbecco's modification of Eagle's medium/F12 nutrient mix containing Glutamax-I (Life Technologies, Breda, The Netherlands) and supplemented with $10 \%$ NU-serum IV (Micronic B.V., Lelystad, The Netherlands) and $25 \mu \mathrm{g} / \mathrm{mL}$ ascorbic acid. Cells were cultured in a incubator at $37{ }^{\circ} \mathrm{C}$ and $5 \% \mathrm{CO}_{2}$ overnight, then Millicell - $\mathrm{CM}$ inserts (Millipore, Ettenleur, The Netherlands) containing the materials were placed in the wells and another $500 \mu \mathrm{L}$ culture medium was added. TCP was used as a negative 
control and latex was used as a positive control. Cells were cultured for another 3 days. Then the inserts were removed, the culture medium was replaced with culture medium containing thiazolyl blue (MTT) (Sigma/Aldrich) $(0.65 \mathrm{mg} / \mathrm{mL}$ ).

Cells were cultured for another 4 hours. Then the medium was discarded and the precipitated formazan dissolved in dimethylsulphoxide $(200 \mu \mathrm{L})$. Samples of $60 \mu \mathrm{L}$ of each sample were transferred to a microtiter plate and the absorbance at $540 \mathrm{~nm}$ was measured on a UV-Vis spectro photometer.

\section{b) Cell culture experiment}

Human fibroblasts isolated from donor corneas (obtained from the Corneabank, Amsterdam, The Netherlands), were seeded in 24-wells culture at a density of $10^{4}$ cells/well, and cultured for one week in Iscoves Modified Dulbecco's Medium, supplemented with $10 \%$ Fetal Calf, penicillin $(100 \mathrm{U} / \mathrm{mL})$ and streptomycin $(100$ $\mathrm{mg} / \mathrm{mL}$ ). The medium and the three supplements were purchased from Life Technologies. Flat samples (a quarter of a circular disc (diameter $8 \mathrm{~mm}$, height 0.5 $\mathrm{mm})$ ) of materials A - C ( $n=4)$ were placed upon the cells. The cells together with the biomaterials were cultured for 3 weeks.

Similar experiments with materials A - C were performed with the epithelial cellular outgrowths of corneal rims obtained from human donor corneas (Corneabank, Amsterdam, The Netherlands). The materials were cultured together with the corneal rim biopsies.

All cells were cultured at $37^{\circ} \mathrm{C}$ and at $5 \% \mathrm{CO}_{2}$. Medium was changed twice a week. Phase contrast photography and histology (toluidin blue) were performed after 3 weeks to evaluate cellular adhesion and proliferation. 


\subsection{Results and discussion}

\subsubsection{Physico-chemical analysis}

\section{a) Solution co-polymerization of DMAEMA or NVP with HEMA}

These experiments were performed in order to get insight into the relative reactivity of the participating monomers. ${ }^{17}$ Figure 3.1 shows expansions of the ${ }^{1} \mathrm{H}$ NMR spectra which were recorded as the reaction DMAEMA + HEMA + AIBN proceeded. All data in Figure 3.1 refer to the molar ratio DMAEMA : HEMA = $1: 1$. Expansions (a) - (c) were taken from the spectrum which was measured shortly after the polymerization started.
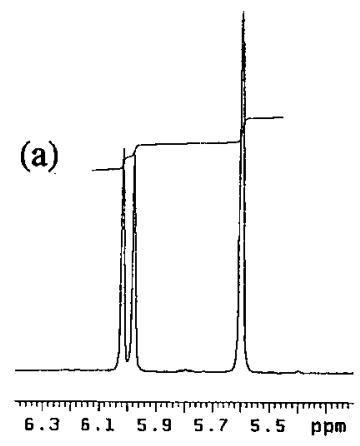

9.48

(d)

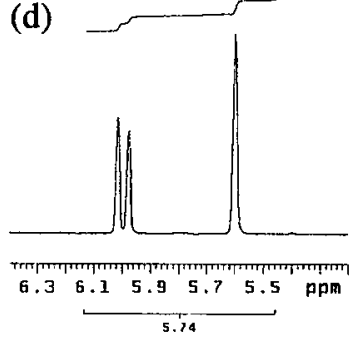

(b)

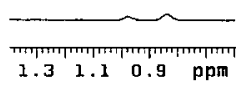

(e)

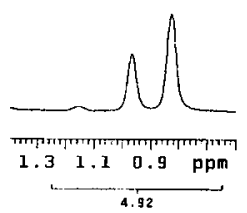

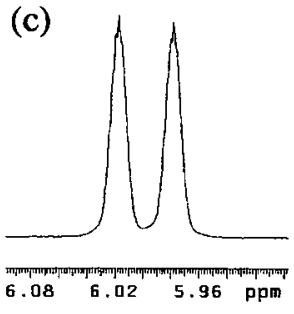

(f)

(c)

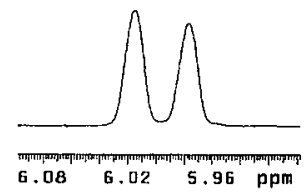

Figure 3.1: Panels (a) - (c): expansions of the ${ }^{1} H$ NMR spectrum of a monomeric mixture of HEMA and DMAEMA at $75^{\circ} \mathrm{C}$ at $t=0$. Panels $(d)-(f)$ : expansions of the ${ }^{\prime} H$ NMR spectrum of the reaction mixture at $75{ }^{\circ} \mathrm{C}$ during the polymerization. 
Expansions (d) - (f) were abstracted from the spectrum which was run approximately $100 \mathrm{~min}$ later; the conversion at this point was approximately $36 \%$ (Figure 3.1). Expansions (a) and (d) show the resonances of the olefinic protons in monomers DMAEMA and HEMA. Obviously, these resonances decay as the reaction proceeds. Patterns (b) and (e) correspond with the $\mathrm{CH}_{3}$ protons, which are attached to the polymer chains. These resonances are broadened and become more intense with increasing conversion, as is evident from comparison of (b) and (e). Patterns (c) and ( $f$ ) are further expansions of (a) and (d), respectively. These peaks correspond with the trans olefinic protons with respect to the $\mathrm{CH}_{3}$ groups of HEMA and DMAEMA. The left peaks in (c) and (f) correspond with HEMA, and the right peaks correspond with DMAEMA. The conversion at the time of measurement of (d) - (f) can be calculated from the integrals in (d) and (e). The integrals of the two separate peaks in expansions (c) and (f) (and those at the other time-points) provided information on the ratio [unreacted DMAEMA] : [unreacted HEMA]. These data are compiled in Figure 3.2, which shows that the ratio remains close to unity with increasing conversion. Figure 3.2 also shows the data which were obtained by studying the reaction NVP + HEMA + AIBN under exactly the same conditions.

The ratio DMAEMA/HEMA and NVP/HEMA were measured as a function of the conversion. The ratios were calculated in the following manner :

$$
\begin{aligned}
& \text { Ratio DMAEMA/HEMA }=I_{\nu} / I_{u} \\
& I_{n}= \text { integral of the trans olefinic proton of unreacted } \\
& \text { DMAEMA }(\delta 6.1 \mathrm{ppm}) \\
& I_{n}=\quad \begin{array}{l}
\text { integral of the trans olefinic proton of unreacted HEMA } \\
(\delta 6.0 \mathrm{ppm})
\end{array}
\end{aligned}
$$




$$
\begin{aligned}
\text { Ratio NVP/HEMA } & =I_{N} I_{H} \\
I_{N}=\quad & \text { integral olefinic proton }(\mathrm{NCH}=\mathrm{C}) \text { of unreacted NVP } \\
& (\delta 6.8-7.0 \mathrm{ppm}) \\
I_{H}=\quad & \text { integral of the trans olefinic proton of unreacted } \\
& \text { HEMA }(\delta 6.0 \mathrm{ppm})
\end{aligned}
$$

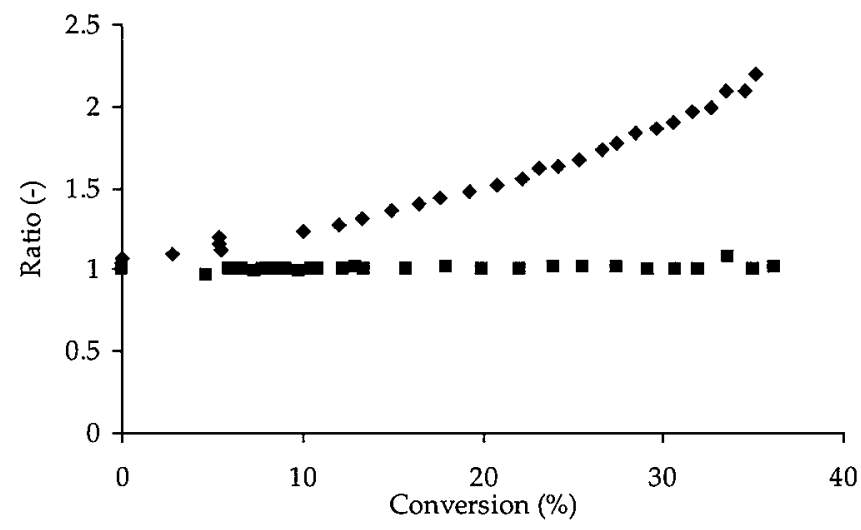

Figure 3.2: Mol/mol ratio's DMAEMA/HEMA (四) and NVP/HEMA ( $\bullet$ plotted versus the conversion (\%); the data series refer to initial molar ratios DMAEMA :HEMA $=1: 1$ and NVP :HEMA =1:1.

Clearly, the ratio [unreacted NVP] : [unreacted HEMA] increases substantially as the reaction proceeds. This reflects that HEMA is more reactive than NVP. We realize that the observation that the ratio [unreacted DMAEMA] : [unreacted HEMA] remains close to unity does not prove that both building blocks react to form a random Bernouillian-type copolymer. The data do not discriminate between: (i), formation of the random-type copolymer; (ii), formation of poly(DMAEMA) and poly(HEMA) at the same rate; or (iii), formation of an ABABABAB-type alternating copolymer. It was found, however, that the ratio [unreacted DMAEMA] : [unreacted HEMA] also remains constant when the reaction is run for other ratios, including $4: 1$ and $1: 4$ as the upper and lower extreme values. The interpretation of these data is that DMAEMA and HEMA react to form a random Bernouilliantype copolymer. 


\section{b) Analysis of free monomer content in materials A - D by FT-IR}

FT-IR measurements were performed on the dry state of materials A - D. This technique reveals the presence or absence (vibration bands at $1700-1650 \mathrm{~cm}^{-1}$ ) of unreacted double bonds. The spectra show that there is free monomer present in materials A - D. Interestingly, the presence of unreacted methacrylates is dependent on the amount of crosslinker used. The more crosslinker is used, the less free double bonds are present. ${ }^{18}$ The decay of the vibration bands of the double bonds in materials A - D, at $1700-1650 \mathrm{~cm}^{-1}$ is clearly seen in Figure 3.3 .

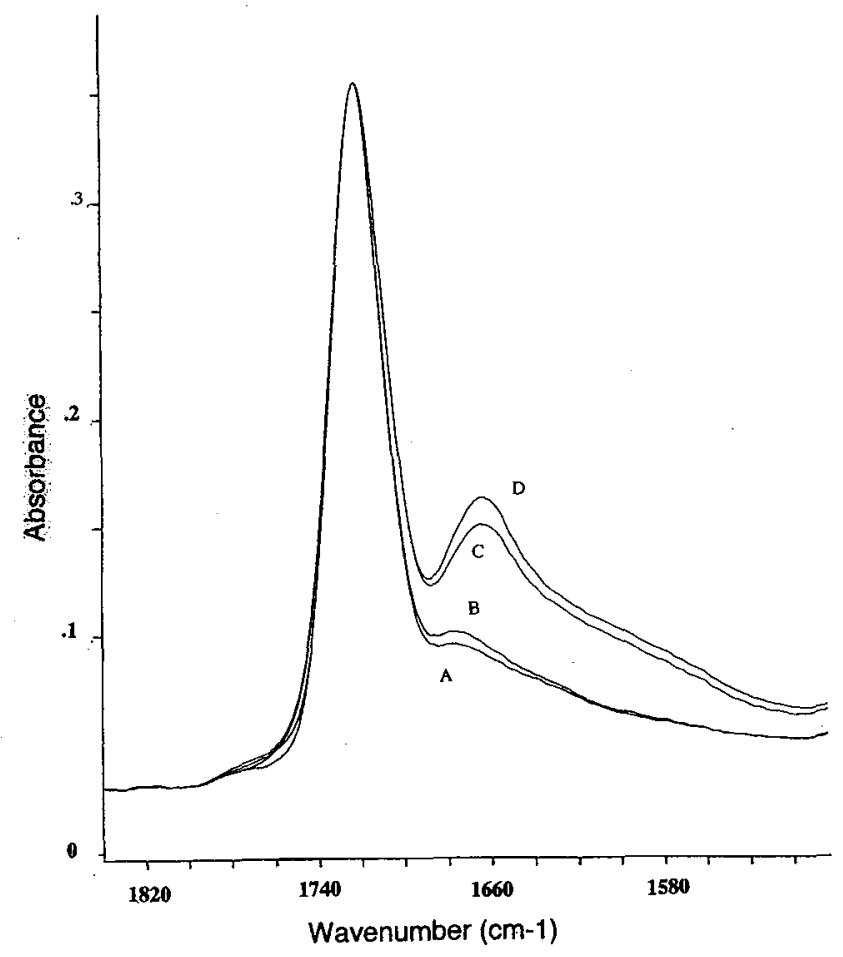

Figure 3.3: FT-IR spectra of materials $A-D$.

\section{c) Analysis of materials A - C by DMTA}

The DMTA measurements performed on materials A - C, provide information about their relative crosslink density. When a material is crosslinked, it is expected 
that $\mathrm{Tg}$ shifts to higher temperature, which was also seen in this experiment. The $\mathrm{T}_{\mathrm{g}}$ shifts to higher temperature with increasing crosslink density, implying an increase of junction point concentration. Material $\mathrm{C}$ has a $\mathrm{Tg}$ of $41.6{ }^{\circ} \mathrm{C}$, material $\mathrm{B}$ has a $\mathrm{Tg}$ of $46.7^{\circ} \mathrm{C}$, and material $\mathrm{A}$ has a $\mathrm{Tg}$ of $47.9^{\circ} \mathrm{C}$. Next to the fact that $\mathrm{Tg}$ increases, the glass-rubber transition also becomes broader and less distinct as the material becomes more crosslinked as shown in Figure 3.4. This is another indication that the degree of crosslinking increases in the $\operatorname{order} \mathrm{C}<\mathrm{B}<\mathrm{A}$.

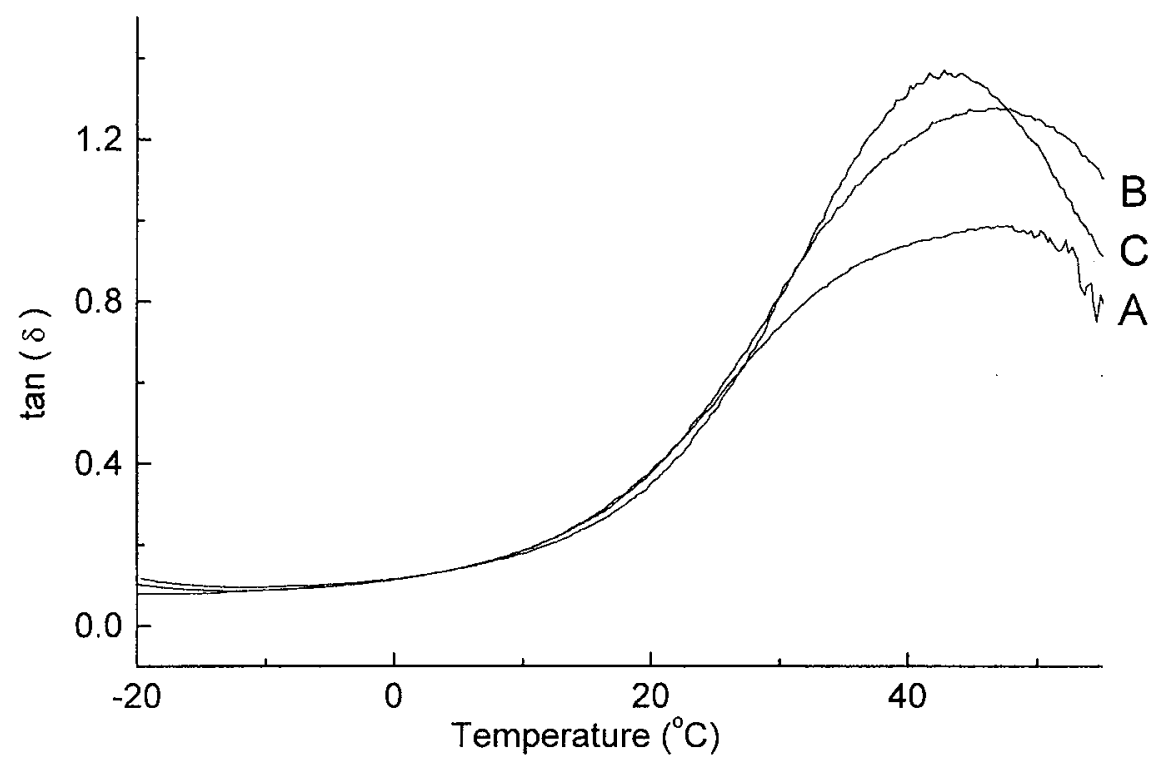

Figure 3.4: Results from the DMTA experiments on materials $A-C$. The Tg values for materials $A-C$ are: $47.9^{\circ} \mathrm{C}, 46.7^{\circ} \mathrm{C}$ and $41.6^{\circ} \mathrm{C}$, respectively.

\section{d) Scanning electron microscopy of materials A - C}

Scanning electron micrographs of materials $A-C$ were taken of the freeze-dried samples in the dry state, and after incubation in the $\mathrm{pH} 9.1$ buffer solution for either 18 days (materials $\mathrm{A}$ and $\mathrm{B}$ ) or 22 days (material C). In the dry state, all materials have a similar continuous non-porous structure. Figure 3.5a shows the dry form of material $\mathrm{C}$ as a typical example. Incubation in the buffer generates pores in the 
structure, as is evident in Figures $3.5(\mathrm{~b}-\mathrm{d})$. The SEM pictures show that there is a clear difference in density of the materials, due to the fact that different amounts of crosslinker are incorporated. Materials B and C clearly have larger pores than material A. This is related to the fact that these materials are much less crosslinked as compared to $\mathrm{A}$. The fact that $\mathrm{CO}_{2}$ is generated during the decomposition may lead to expansion of the structural cavities. 

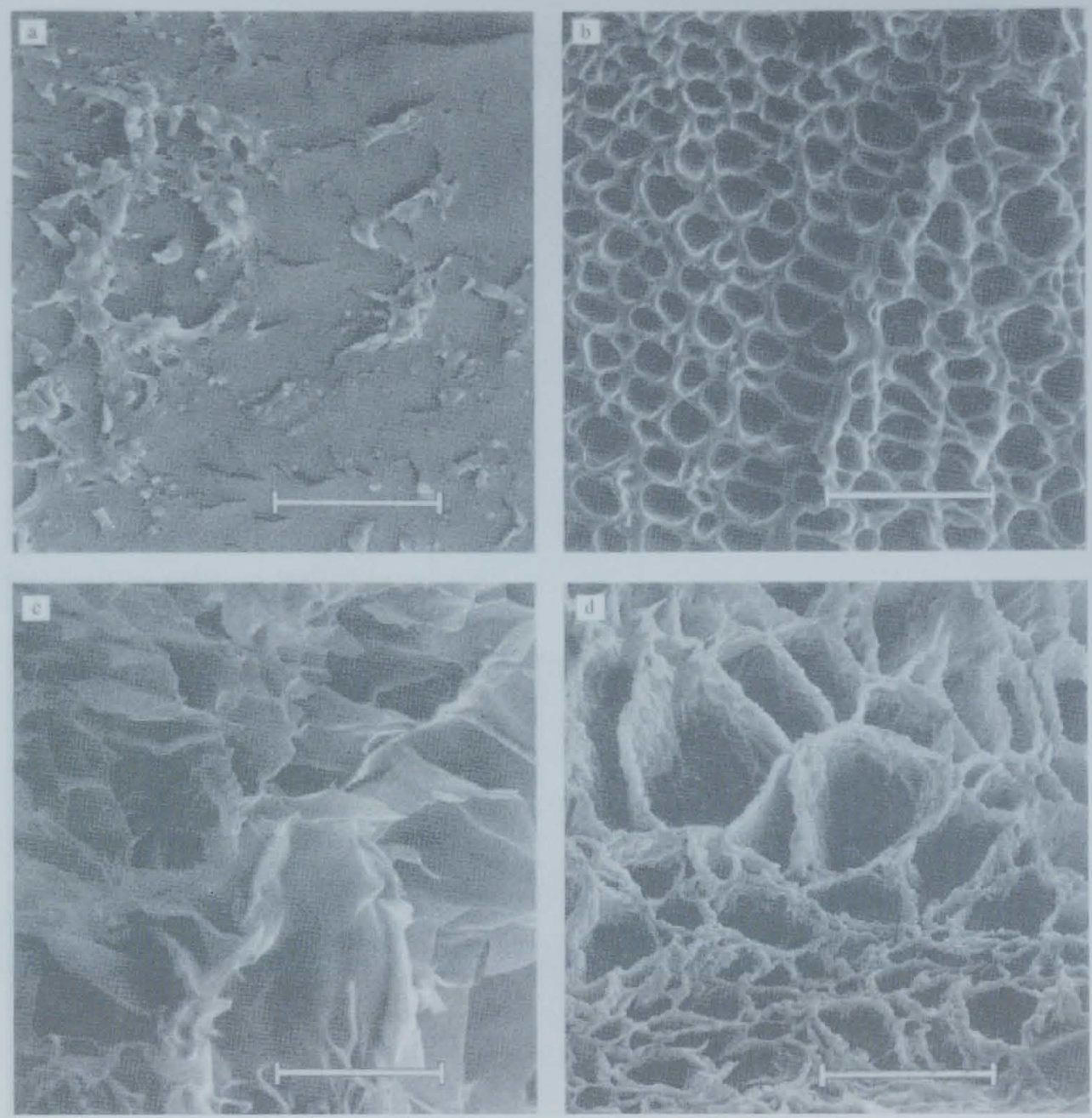

Figure 3.5: (a) SEM micrographs of material $\mathrm{C}$ in dry state. Highly comparable images were obtained for materials $A$ and $B$ in the dry state. (b) SEM micrographs of material $A$ after 18 days of incubation in a borax solution. (c) SEM micrographs of material $B$ after 18 days of incubation in a borax solution (d) SEM micrographs of material $\mathrm{C}$ after 22 days of incubation in a borax solution. Bar $=100 \mu \mathrm{m}$. 
e) Degradation/dissolution of materials $\mathrm{A}-\mathrm{C}$ in vitro

Figures 3.6-3.8 give a graphical representation of the full data set. It is clear

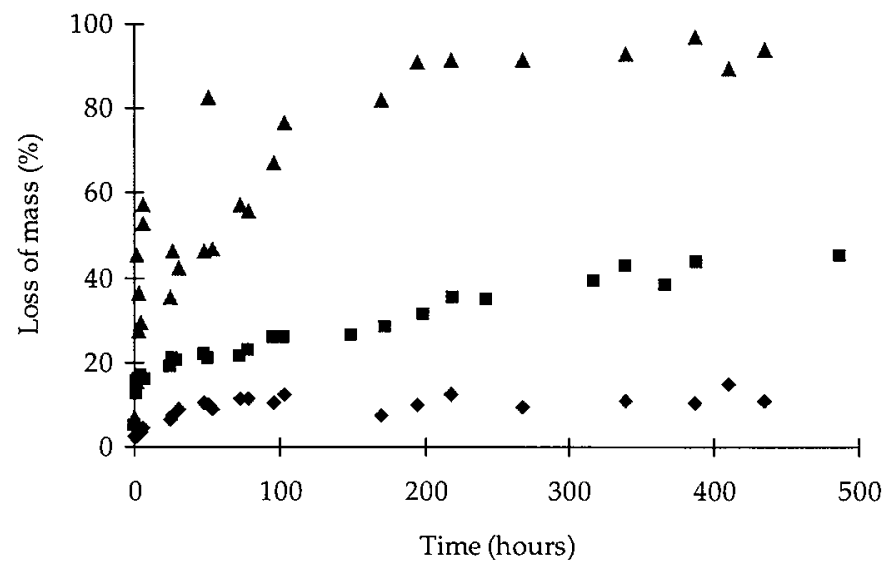

Figure 3.6: Loss of mass (\%) of materials $A(\bullet), B(\mathbf{\square}), C(\mathbf{\Delta})$ incubated in a PBS buffer solution ( $p H 7.4)$, plotted versus time.

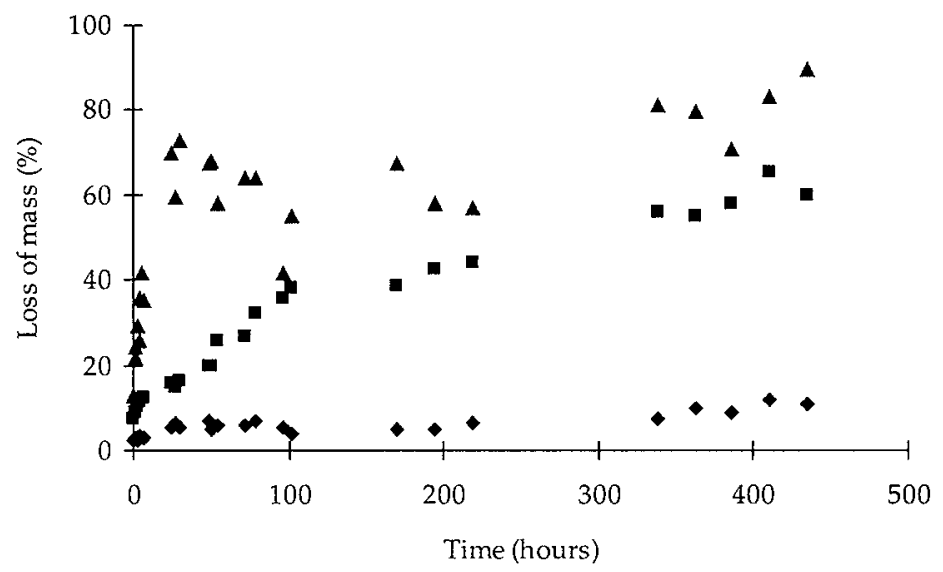

Figure 3.7: Loss of mass (\%) of materials $A(\bullet), B(\mathbf{D})$ and $C(\boldsymbol{\Delta})$ incubated in a borax buffer solution ( $p H$ 9.1), plotted versus time. 


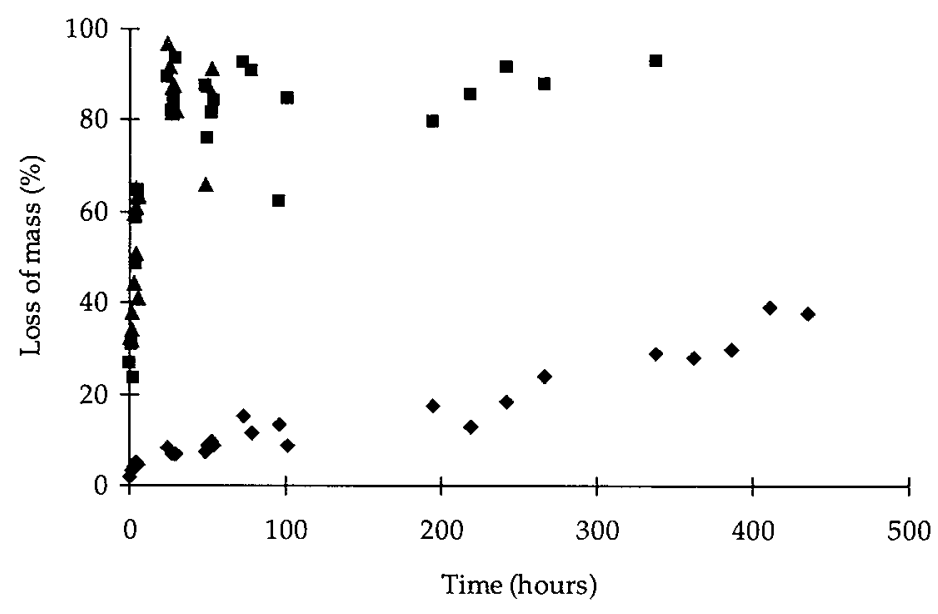

Figure 3.8: Loss of mass (\%) of materials $A(\bullet), B(\boldsymbol{\square})$ and $C(\mathbf{\Delta})$ incubated in a saturated calcium hydroxide solution ( $p H$ 12.0), plotted versus time.

that the rate of degradation/dissolution increases in the order $\mathrm{A}<\mathrm{B}<\mathrm{C}$. These results show that an increased degree of crosslinking corresponds with an increased hydrolytic stability. Degradation of material A is very slow at $\mathrm{pH} 7.4$ and 9.1: only approximately $10 \%$ loss of mass is found after 3 weeks. The decomposition of material $\mathrm{A}$ is somewhat accelerated at $\mathrm{pH}=12.0$ (approximately $25 \%$ loss of mass after 3 weeks). The process of degradation of material B is significantly faster. Approximately $50 \%$ loss of mass is found after 3 weeks at $\mathrm{pH} 7.4$ and 9.1. Formation of small gas bubbles (presumably $\mathrm{CO}_{2}$ ) was noted inside the swollen remnants of the polymeric discs. At $\mathrm{pH}=12.0$, the degradation is again faster: the loss of mass has exceeded $80 \%$ after approximately 4 days. Degradation of material $\mathrm{C}$, which is hardly crosslinked, proceeds very quickly at $\mathrm{pH} 7.4,9.1$ and 12.0. These results are in line with previous observations, made with analogous NVP $+\mathbf{1}$ networks, that the kinetics of degradation/dissolution depend strongly on the crosslink density. These results establish that the decomposition probably involves hydrolytic scission of the carbonate bonds in the crosslinks. The observation of the formation of small gas bubbles during degradation of material $C$ supports this idea. 
The degradation processes all proceed smoothly, i.e. there are no indications for the occurrence of a boost-effect during the degradation.

The results indicate that the degradation kinetics remain unchanged in the $\mathrm{pH}$ interval 7.4 - 9.1. Our explanation for this is that the acceleration effect of increasing the $\mathrm{pH}$ from 7.4 to 9.1 is counterbalanced by the fact that the hydrophilicity of materials A - C decreases simultaneously. The pKa of poly(DMAEMA) is approximately 8 . Thus, more than $50 \%$ of the dimethylamino groups in materials $\mathrm{A}$ - $\mathrm{C}$ are protonated at $\mathrm{pH} 7.4$, which renders the materials charged and hydrophilic. At $\mathrm{pH}$ 9.1, on the other hand, the dimethylamino groups are predominantly nonprotonated, leading to a more hydrophilic nature of materials $\mathrm{A}-\mathrm{C}$.

\subsubsection{Cytotoxicity and biocompatibility of the polymeric materials}

\section{a) MTT assay}

Materials A, C and D proved to be cytotoxic to SW1353 chondrosarcoma cells in the MTT assay (Figure 3.9). In the case of exposure to materials A and C approximately, $30 \%$ of the cells survived, whereas in the case of material D only $6 \%$ survived. These data (Figure 3.9) are relative to TCP as the negative control. Materials A and $C$ are crosslinked and therefore do not go into solution as material $D$. In this way less extractables can escape from material $A$ and $C$ in comparison with material D. The influence of these materials on the local $\mathrm{pH}$ of the medium can cause cell death. Also the leachables (free monomers) are most likely lethal to the cells. 


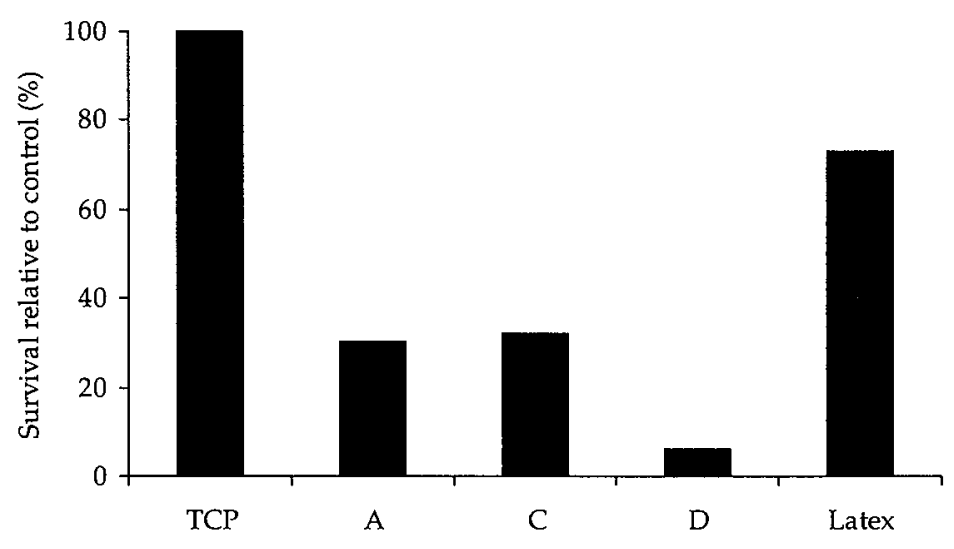

Figure 3.9: Survival percentages of SW1353 chondrosarcoma cells in the MTT assay, after being exposed to material A (approximately $30 \%$ ), C (approximately $32 \%$ ) and D (approximately $6 \%$ ) with regard to TCP (100\%, negative control). Latex is a positive control (approximately $73 \%$ ).

\section{b) Cell culture experiments}

In both culture systems the cells did not tolerate materials A - C. Cells did not adhere or proliferate. Cells rounded off and died when they came in direct contact with the material (Figure 3.10 (a)). In case of the corneal rims, the further the materials were away from the corneal biopsies, the better the cellular outgrowth was. However, when the material was close to the rims cells rounded off and died. The control cultures with no material inserted showed nice outgrowth of cells (Figure 3.10 (b)). A possible explanation for the cytotoxicity and bio-incompatibility of the material is probably due to $\mathrm{pH}$ changes of the medium and the leakage of free monomers. 


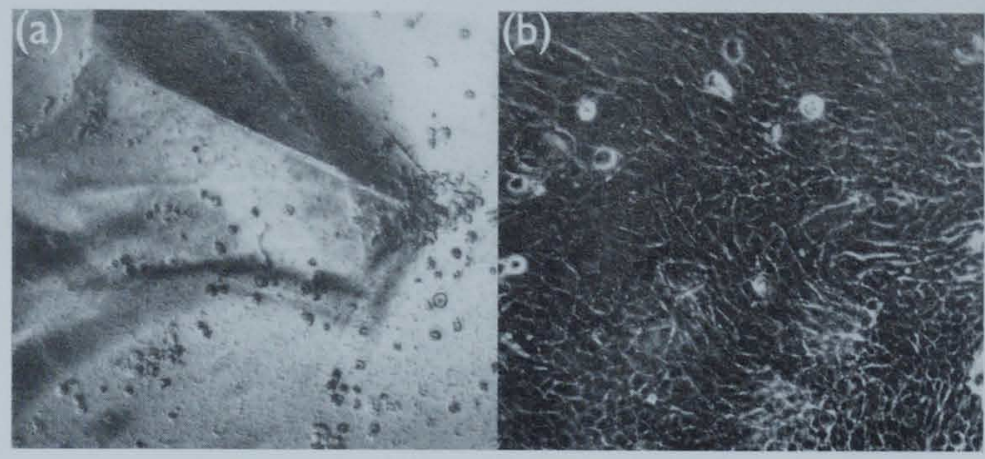

Figure 3.10: (a) Epithelial outgrowth of a corneal rim, cultured together with material A (upper left corner), after 3 weeks. The cells rounded off and died. Original magnification: 40X. (b) Epithelial outgrowth of a corneal rim after 3 weeks (a reference). Original magnification: $100 \mathrm{X}$.

\subsection{Concluding remarks}

Synthesis provides a suitable means to control the kinetics of degradation of the new three-dimensional networks. Degradation is clearly dependent on the crosslink density and not very sensitive to acidity around physiological pH. From a physicochemical point of view, these materials are attractive with regard to applications as matrices for controlled local drug delivery. The marked cytotoxicity of the materials, however, precludes their use as matrix materials for intraocular drug delivery. These materials obviously do not meet the requirement of excellent biocompatibility, which is absolutely mandatory for applications in ophthalmology.

\section{5}

\section{References}

1. Wesendahl T.A.; Shalaby, W.; Corson, D.W.; Auffarth, G.U.; Apple, D.J. Ophthalmol. 1996,93, 22; (b) Yaacobi, Y.; Israel, A.A.; Goldberg, E.P. J. Surg.Res. 1993, 55, 422.

2. Reimer, K.; Fleischer, W.; Brogmann, B.; Schreier, H.; Burkhard, P.; Lanzendorfer, A.; Gumbel, H.; Hoekstra, H.; Behrens-Baumann, W. Dermatolog. 1997, 195 (Suppl 2), 93.

3. Yu-Chin, L. J. Polym. Sci. A: Polym. Chem. 1997, 35, 1039. Arora, A.; (b) Carver-Ward, J.A.; Jaroudi, K.A.; Sieck, U.V. Fert. Ster. 1994, 61, 979. 
4. Bruining, M.J.; Edelbroek-Hoogendoorn. P.S.; Blaauwgeers, H.G.T.; Mooy, C.M.; Hendrikse, F.H.; Koole, L.H. J. Biomed. Mater. Res. 1999, 47, 189.

5. Li, S.; McCarthy, S. Biomaterials 1999, 20, 35; (b) Tracy, M.A.; Ward, K.L.; Firouzabadian, L.; Wang, Y.; Dong, N.; Qian, R.; Zhang, Y. Biomaterials 1999, $20,1057$.

6. Gonzalez, M.F.; Ruseckaite, R.A.; Cuadrado, T.R. J. Appl. Pol. Sci. 1999, 71, 1223.

7. Göpferich, A. Biomaterials 1996, 17, 103.

8. Veloso, A.A. Jr; Zhu, Q.; Herrero-Vanrell, R.; Refojo, M.F. Invest. Ophthalmol. Vis. Sci. 1997, 38, 665.

9. Hashizoe, M.; Ogura, Y.; Takanashi, T.; Kunou, N.; Honda, Y.; Ikada, Y. Curr. Eye. Res. 1997, 16, 633.

10. Zhou, T.; Lewis, H.; Foster, R.E.; Schwendeman, S.P. J. Control. Release 1998, 55, 281.

11. Shepherd, W.F.I.; Fsadni, M.G.; Raj, P.S. Ocular Immunology and Inflammation 1998, 6, 13.

12. Domb, A.J.; Bentolila, A.; Teomin, D. Acta Polym. 1998, 49, 526.

13. Hong, Y.; Chirila, T.V.; Vijayasekaran, S.; Shen, W.; Lou, X.; Dalton, P.D. J. Biomed. Mat. Res. 1998, 39,650 .

14. Vijayasekaran, S.; Chirila, T.V.; Hong, Y.; Tahija, S.G.; Dalton, P.D.; Constable, I.J.; McAllister, I.L. J. Biomater. Sci. Polym. Ed. 1996, 7, 685.

15. Hong, Y.; Chirila, T.V.; Vijayasekaran, S.; Dalton, P.D.; Tahija, S.G.; Cuijpers, M.J.H.; Constable I.J. J. Biomed. Mater. Res. 1996, 30, 441.

16. Lindemann, B.; Schröder, U.P.; Oppermann, W. Macromolecules 1997, 30, 4073.

17. Kruft, M.A.B.; Koole, L.H. Macromolecules 1996, 29, 5513.

18. Duracher, D.E.; Pichot, C. J. Polym. Sci. Part A: Polym. Chem. 1999, 37, 1823. 


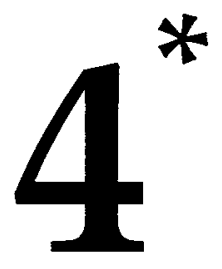

NMR Microimaging as a Versatile Tool for Studying Water-Uptake and

Decomposition of Hydrophilic and Degradable Biomaterials 


\section{Summary}

Biodegradable hydrogels, prepared from 1-vinyl-2-pyrrolidinone (NVP) and the crosslinker system 1, were studied with nuclear magnetic resonance (NMR) microimaging. After immersion in an aqueous environment, these materials show concomitant water uptake and decomposition; the latter is due to hydrolysis of<smiles>C=C(C)C(=O)OCCOCCOC(=O)OCCOCCOCCOC(=O)OCOCCOC(=O)C(=C)C</smiles>

the carbonate groups in 1 . The decomposition reaction leads to the formation of carbondioxide, oligo(NVP) and poly(NVP); i.e., no products which could catalyze the ongoing decomposition process are formed. These materials are potentially useful as temporary drug depots, especially for intraocular use. The use of NMR microimaging, a non-invasive technique, expanded our comprehension of water uptake and degradation of these materials.

\subsection{Introduction}

Devices for controlled local delivery of drugs are frequently based on poly(lactic acid) or poly(lactic-co-glycolic acid), which are biodegradable materials..$^{1-4} \mathrm{~A}$ drawback of these materials is that the kinetics of their breakdown in situ is irregular. Hydrolysis of the ester bonds shows a sudden burst-effect, and concomitant release of substantial amounts of acidic degradation products can evoke inflammatory responses. This adverse reaction is directly correlated with the burst degradation of the polymeric matrix and with the chemical composition of the degradation products. 
A new family of biodegradable polymers, which show decomposition according to a more regular surface-erosion mechanism has been developed recently. ${ }^{5.6}$ These materials are crosslinked three-dimensional networks built of NVP, and a crosslinker that contains two carbonates, which are susceptible to hydrolysis. The structures of the crosslinkers $\mathbf{1}$ and 2, are shown in Figure 4.1.

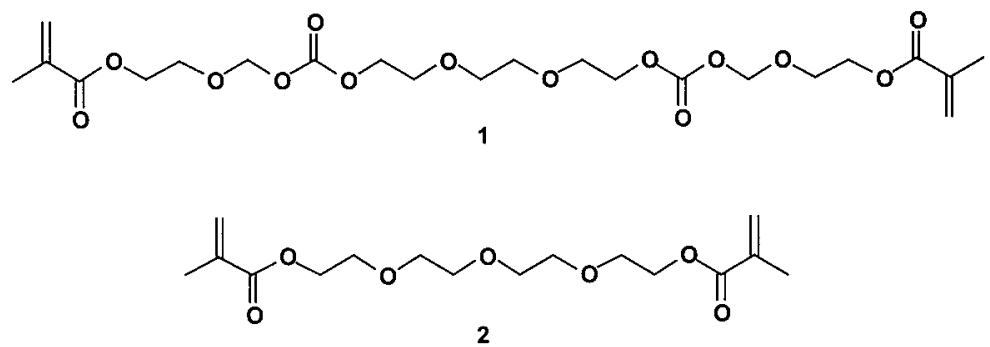

Figure 4.1: The molecular structure of the biodegradable crosslinker, 1, and the stable crosslinker, 2.

Hydrolysis of the networks does not lead to the formation of acidic or basic products which could catalyze the ongoing degradation process. The content of the crosslinker has an important impact on the degradation kinetics. Increasing crosslinker content results in slower water uptake and longer degradation times, and the opposite is achieved when the crosslinker content is decreased. The degradation products are $\mathrm{CO}_{2}$ oligo(NVP) and poly(NVP). Oligomers and polymers of NVP have also been used as vitreous substitutes ${ }^{710}$ it is for this reason that these biodegradable materials were tested for the possible utility as temporary drug carriers in the vitreous body of rabbits. ${ }^{5}$

Water uptake and degradation of the three-dimensional networks NVP +1 is a complex process. A detailed study on three NVP +1 networks (5, 10, and $15 \mathrm{~mol} \%$ of 1 ), and an analogous series of NVP +2 counterparts is reported in this chapter. Note that 2 (tetraethyleneglycol dimethacrylate) is a stable, non-degradable equivalent of 1 , i.e., the networks NVP +2 show merely water uptake and swelling but no decomposition, albeit that the uptake of water by NVP +2 will be accompanied by the release of leachables (oligomers and polymers of NVP that 
were not engaged in the crosslinking). The response of the different threedimensional networks NVP $+\mathbf{1}$ and NVP +2 to immersion in water was studied with NMR microimaging. ${ }^{11-13}$ This non-invasive technique allowed us to monitor the penetration of water into the different specimens in great detail. This approach revealed new insights in swelling and degradation of these materials.

\subsection{Experimental section}

\subsubsection{Materials}

\section{a) Chemicals}

Starting materials and solvents were of the highest available purity or were purified as specified. NVP was purified by distillation in vacuo, and stored at $-18{ }^{\circ} \mathrm{C}$. Compound 2, which contained hydroquinone as inhibitor, was purified through treatment with inhibitor remover (Aldrich Catalogue 2000 - 2001, page 989, item 30,631-2). Pure 2 (checked by ${ }^{1} \mathrm{H}$ NMR) was stored at $-18^{\circ} \mathrm{C}$.

\section{b) Synthesis of the biodegradable crosslinker}

Crosslinker $\mathbf{1}$ was prepared in two steps: ${ }^{5}$ The synthesis of $\mathbf{1}$ is described in Chapter 2 (2.2.1 Materials).

\section{c) Preparation of the polymeric specimens}

All materials studied in this work are hydrophilic polymeric networks consisting of either NVP and 1, or NVP and 2. The network NVP +1 was prepared as follows: NVP (10 $\mathrm{g}, 90 \mathrm{mmol})$ and $1(2.3 \mathrm{~g}, 5 \mathrm{~mol} \%)$ and the photoinitiator(2,2 dimethoxy-2phenyl acetophenone) $(48.4 \mathrm{mg}, 0.2 \mathrm{~mol} \%$ ) were weighed into a small flask. The mixtures were homogenized using an ultrasonic bath. All other materials were synthesized analogously. Aliquots of the mixture $(500 \mu \mathrm{L})$ were transferred into cylindrical Teflon molds, with diameter $15 \mathrm{~mm}$ and depth $10 \mathrm{~mm}$. The molds were then irradiated with a Philips HPA 1000 high power UV light source (300 - $400 \mathrm{~nm})$. 
The distance between the lamp and the specimens was approximately $10 \mathrm{~cm}$; irradiation time was $20 \mathrm{~min}$. This afforded the desired coin-like discs (height \pm 2 $\mathrm{mm}$ ). The discs were removed from the molds, turned upside down, and irradiated for another $20 \mathrm{~min}$. The specimens were then stored in a closed vial under ambient dry conditions. Table 4.1 compiles the compositions of the different specimens.

Table 4.1: Degradable and Non Degradable Hydrophilic Polymeric Networks based on NVP.

\begin{tabular}{|l|l|}
\hline $\begin{array}{l}\text { Copolymers of } \\
\text { NVP }+\mathbf{1} \text { (mol ratios) }\end{array}$ & $\begin{array}{l}\text { Copolymers of } \\
\text { NVP }+2 \text { (mol ratios) }\end{array}$ \\
\hline $95: 5$ & $95: 5$ \\
\hline $90: 10$ & $90: 10$ \\
\hline $85: 15$ & $85: 15$ \\
\hline
\end{tabular}

\subsubsection{Methods}

\section{a) ${ }^{1} H$ NMR and NMR microimaging}

${ }^{1} \mathrm{H}$ NMR and ${ }^{13} \mathrm{C}$ NMR spectra were recorded at 399.9 and $100.6 \mathrm{MHz}$, respectively, on a Varian Unity-Plus NMR spectrometer with variable temperature facilities. $\mathrm{CDCl}_{3}$ was used as solvent and tetramethylsilane was used as the internal standard $(\delta=0.00 \mathrm{ppm})$.

NMR microimaging was performed with a Varian Unity-Plus system, comprising a supercooled wide-bore magnet $(89 \mathrm{~mm})$ operating at a magnetic field strength of 9.4 $\mathrm{T}$ (corresponding with a proton frequency of $400 \mathrm{MHz}$ ). The gradient coil and the micro-imaging probe were manufactured by the Fraunhofer Institute (Ingelheim, Germany). A maximum magnetic-field gradient up to $50 \mathrm{G} / \mathrm{cm}$ can be generated by the gradient coil. The microimaging probe was equipped with an insert containing a cylindrical sample-space (diameter $25 \mathrm{~mm}$; effective height approximately 20 $\mathrm{mm}$ ). The sample temperature was controlled via a thermocouple/heater system, and maintained at $22^{\circ} \mathrm{C}$ throughout all imaging experiments. 
In all imaging experiments, two samples were measured simultaneously; one on the basis of the degradable crosslinker $\mathbf{1}$, and one with the same composition, except that 1 was replaced by its stable counterpart, 2 . Both discs were placed in a specially designed sample holder (Figure 4.2). At the start of the experiment, the samples were immersed in distilled water. The sample was then inserted into the magnet.

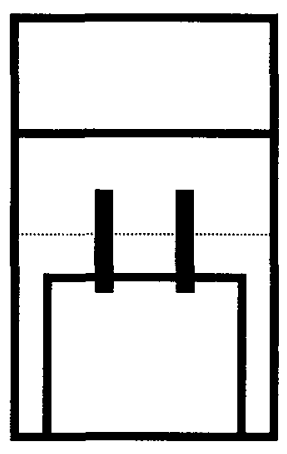

A

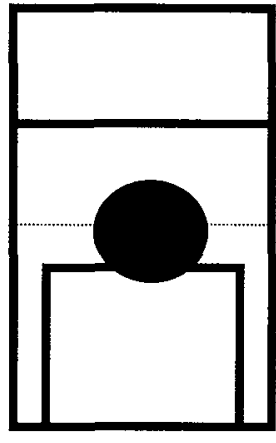

B
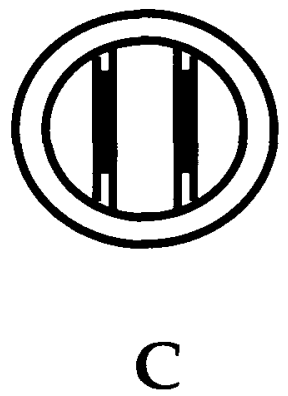

Figure 4.2: (A), (B) side views, and (C) top view of the sample and sample holder used in the NMR microimaging experiments. Two polymeric discs were placed vertically in the cylindrical sample holder. The dashed line represents the horizontal cross-section in which water penetration was monitored.

The magnetic field was homogenized quickly, and one vertical slice with a thickness of $600 \mu \mathrm{m}$ was measured within two min. This quick experiment served to determine the exact position of the sample; enabling to define where the horizontal transverse slices were measured. Using the SEMS protocol, one slice was measured (thickness: $600 \mu \mathrm{m}$ ). A $512 * 512$ data matrix; this resulted in a pixel size of $30 \times 30$ $\mu \mathrm{m}$. The total time for one data acquisition run was $8 \mathrm{~min}$. and $57 \mathrm{sec}$. Images were measured and stored at regular time intervals. 


\subsection{Results and discussion}

\subsubsection{Polymeric materials based on crosslinked NVP}

Synthesis of 1 proceeded smoothly. All polymerizations afforded the desired materials as transparent discs with uniform diameter. Most of the samples showed a hollow meniscus. The thickness of all samples was adjusted to $2.0 \mathrm{~mm}$ by careful machining.

\subsubsection{Water uptake and decomposition behavior of the hydrogels}
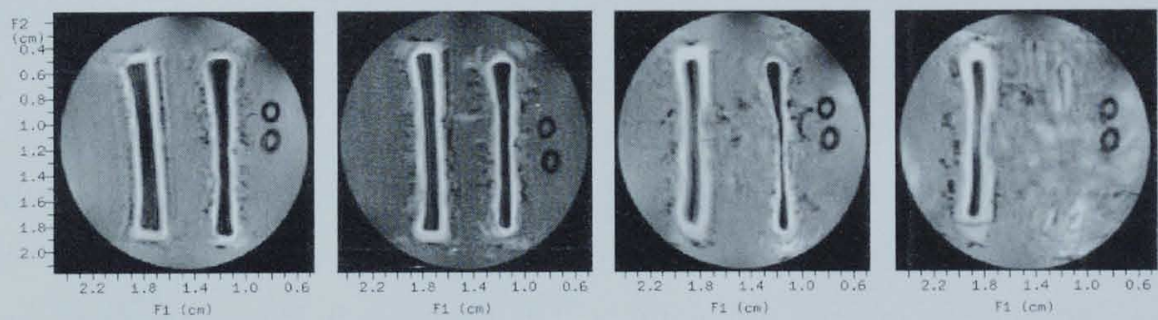

Figure 4.3: Four NMR microimages measured for the NVP + 1 copolymer (right sample in all four images) and the NVP +2 copolymer (left sample in all four images) upon immersion in distilled water. The composition of both materials was NVP : $\mathbf{1}(\mathbf{2})=95: 5$. Going from left to right, the immersion time increases as follows: 36, 46, 59 and $84 \mathrm{~min}$. The vertical circles to the right of each image were used for sample identification.

Figure 4.3 shows a series of four NMR microimages, as measured on the specimens NVP + $1(95: 5)$ and NVP + 2 (95:5). The four images correspond to increasing time of contact with water: $36,46,59$ and $84 \mathrm{~min}$. The images in Figure 4.3 are horizontal slices with thickness $600 \mu \mathrm{m}$, see Figure 4.2. The specimens are displayed as vertical rectangles. Note that the water that surrounds the biomaterial samples is displayed as a gray area. This is the consequence of the fact that the magnetic relaxation of the protons in free water is rather slow $(\mathrm{T} 1=5-10 \mathrm{~s})$. Figure 4.3 (left image) shows the 
specimens after $36 \mathrm{~min}$ of incubation in water. The white boundaries reflect partial penetration of water molecules into the specimens: water incorporated in the polymer matrix has accelerated magnetic relaxation. The inside of both specimens in Figure 4.3 (left image) is devoid of water, and is therefore displayed as a black area. Figures 4.3 (second, third and fourth image) show the same specimens in the course of time. The NVP +2 specimen (left) merely absorbs more water as time proceeds. This is evident from the fact that the white boundaries become broader and the black interior region becomes smaller. The NVP +1 specimen (right) shows not only absorption of water, but also structural decomposition. Figure 4.3 (second image) shows that the specimen became shorter (compare with the first image in Figure 4.3). In Figure 4.3 (third image) it is clear that the specimen became shorter and thinner, and virtually disappeared in Figure 4.3 (fourth image). Note that this striking difference in the behavior of NVP $+\mathbf{1}$ vs. NVP +2 is solely due to the fact that $\mathbf{1}$ is a degradable crosslinker whereas $\mathbf{2}$ is a stable structure.

Two series of analogous experiments were performed. One series was with the materials NVP $+1(90: 10)$ and NVP $+2(90: 10)$, and the other series was with the materials NVP $+1(85: 15)$ and NVP $+2(85: 15)$. The experimental data with the composition $90: 10$ compared well with the data as shown in Figure 4.3, albeit that the processes of swelling and/or degradation were slowed down by approximately a factor two. Figure 4.4 shows NMR microimages which were recorded during simultaneous immersion of NVP $+\mathbf{1}$ and NVP $+\mathbf{2}$ (both $85: 15$ ).

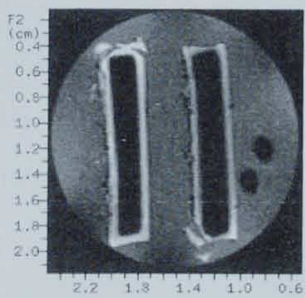

$\mathrm{F1}(\mathrm{cm})$

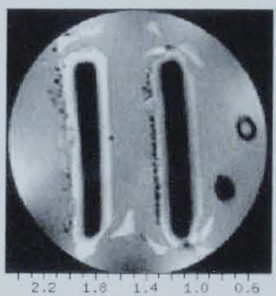

F1 $(\mathrm{cm})$

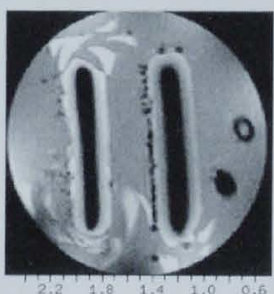

rs (cent)

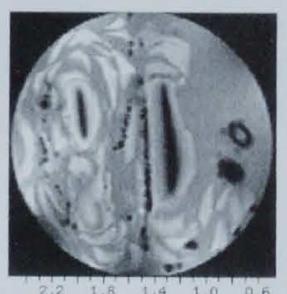

F1 con

Figure 4.4: Analogous series of NMR microimages, as shown in Figure 4.3, but now for NVP : 1(2) = $85: 15$. The immersion times (from left to right) are 70, 125, 188 and $300 \mathrm{~min}$. 
Immersion times are: 70, 125, 188 and $300 \mathrm{~min}$. The water penetration is clearly slower as compared to the $95: 5$ materials (vide supra). Another striking difference is that the $85: 15$ materials became brittle upon uptake of water: both samples gradually broke down into small pieces, presumably due to build-up of excessive forces inside the material during swelling. Such highly crosslinked materials ( $>15$ $\%$ crosslinker ) are unlikely to be useful as matrices for controlled local drug delivery. Figure 4.4 (fourth image) shows that the specimen NVP +2 (left) fell apart in numerous smaller parts. Much less remnants of the specimen NVP + 1 (Figure 4.4 , fourth image) are seen, which is due to the fact that the latter material also shows hydrolytic decomposition.

\subsection{Concluding remarks}

NMR microimaging technique proved to be a useful non-invasive tool for monitoring swelling and degradation processes in hydrogels. Swelling and degradation rates are strongly dependent on the type and the concentration of crosslinker used in the NVP based systems. NVP +2 (reference) materials merely absorb water in the course of time, whereas NVP +1 specimens additionally show structural degradation at their swollen areas. At low crosslink densities (5-10 mol $\%$ this difference in swelling and degradation between the stable and the degradable materials, is most striking. No burst-effects are noted. Crosslinker concentrations of $15 \mathrm{~mol} \%$ and higher lead to very brittle behavior in the swollen state. This renders highly brittle materials, which are probably not useful as matrices for controlled drug delivery. The systems with lower $\mathbf{1}$ content are potentially useful in drug delivery applications. Note that there are several alternative approaches to influence the degradation kinetics. For example, substituting part of the NVP building blocks by a more hydrophobic component will slow down water uptake and the decomposition rate. Alternatively, a crosslinker with only one carbonate group can be used; this will not retard swelling but it will slow down degradation. Ongoing research focuses on further explanation 
of these concepts. It can be concluded that NMR microimaging provided highly valuable and otherwise unattainable information about water uptake and decomposition of our hydrophilic biomaterials. The technique is believed to be widely applicable in comparable studies, especially for (bio)materials that respond to the presence of water by swelling and/or releasing incorporated substances.

\subsection{References}

1. Peppas, N.A.; Bures, P.; Leobandung, W.; Ichikawa, H. Eur. J. Pharm. Biopharm. 2000, 50, 27.

2. Jain, R. A. Biomaterials 2000, 21, 2475.

3. Veloso, Jr. A.A.S.; Zhu, Q.; Herrero-Vanrell, R.; Refojo, M.F. Invest. Ophthalmol. Vis. Sci. 1997, 38, 665.

4. Tracy, M.A.; Ward, K.L.; Firouzabadian, L.; Wang, Y.; Dong, N.; Qian, R.; Zhang, Y. Biomaterials $1999,20,1057$.

5. Bruining, M.J.; Edelbroek-Hoogendoorn, P.S.; Blaauwgeers, H.G.T.; Mooy, C.M.; Hendrikse, F.H.; Koole, L.H. J. Biomed. Mater. Res. 1999, 47,189.

6. Bruining, M.J.; Blaauwgeers, H.G.T.; Kuijer, R.; Pels, E.; Nuijts, R.M.M.A.; Koole, L.H. Biomaterials 2000, 21, 595 .

7. Vijayasekaran, S.; Chirila, T.V.; Hong, Y.; Tahija, S.G.; Dalton, P.D.; Constable, I.J.; McAllister, I.L. J. Biomed. Sci. Polymer. Edn. 1996, 7, 685.

8. Hong, Y.; Chirila, T.V.; Cuypers, M.J.H.; Constable, I.J.J. Biomaterials Applications 1996, 11, 135.

9. Chirila, T.V.; Hong, Y. Polymer-International 1998, 46, 183.

10. Hong, Y.; Chirila, T.V.; Vijayasekaran, S.; Shen, W.Y.; Lou, X.; Dalton, P.D.J. Bioned. Mat. Res. $1998,39,650$.

11. Hyde, T.M.; and Gladden, L.F. Polymer 1998, 39, 811.

12. Kojima, M.; Ando, S.; Kataoka, K.; Hirota, T.; Aoyagi, K.; Nakagami, H. Chem. Pharm. Bull. 1998, 46,324 .

13. Knörgen, M.; Heuert, U.; Schneider, H.; Kuckling, D.; Richter, S.; Arndt, K-F. Macromol. Symp. $1999, \mathbf{1 4 5}, 83$. 


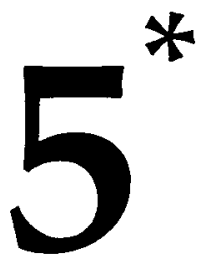

\section{Studies on New Polymeric Biomaterials}

\section{with Tunable Hydrophilicity, and their}

\section{Possible Utility in Corneal Repair}

\section{Surgery}

*Bruining, M.J.; Blaauwgeers, H.G.T.; Kuijer, R.; Jongsma, F.H.M.; de Brabander, J.; Nuijts, R.M.M.A.; Koole, L.H. Bio-Macromolecules 2000, 1, 418; Bruining, M.J.; Pijpers, A.P.; Kingshott, P.; Koole, L.H. Biomaterials 2001, submitted. 


\section{Summary}

A well-known complication in corneal repair surgery is (recurrent) rejection of donor corneal tissue, particularly in patients suffering from auto-immune diseases such as rheumatoid arthritis. Down-regulation of their immune system, by means of drugs, is necessary in order to perform an allograft implantation afterwards. The patient may need a temporary prosthetic cornea while the immune system is inactivated. Recently, NeuroPatch ${ }^{\oplus}$, a mesh-type polyurethane, was used for this purpose. The material exhibits excellent biocompatibility and allows ingrowth of stromal fibroblasts which deposit matrix material into the pores. A serious drawback of NeuroPatch ${ }^{\oplus}$ is its non-transparency, which impairs vision. In this work an attempted was made to develop an improved biomaterial that combines the advantages of NeuroPatch ${ }^{\otimes}$ with optical transparency. Such a biomaterial must meet stringent requirements in terms of hydrophilicity, strength, transparency, flexibility and biocompatibility. Four different copolymers of $n$-butyl methacrylate (BMA) and hexaethyleneglycol methacrylate (HEGMA) were prepared and characterized. Poly(BMA) was made as a reference material. Copolymerizations were studied by means of ${ }^{1} \mathrm{H}$ NMR. Physico-chemical properties were measured (contact angles, glass-transition temperatures, thermal degradation, water uptake and swelling), and cytotoxicity in vitro was assessed with a MTT test. Moreover, the interaction between the materials and cultured human corneal epithelial cells was studied. The influence of the HEGMA content on the resistance of protein adsorption was also studied. The results indicate that materials with a HEGMA content of approximately $20 \mathrm{~mol} \%$ are potentially useful in corneal repair surgery. This biomaterial meets most of the stringent physical and biological requirements. 


\subsection{Introduction}

Treatment of corneal perforations, resulting from trauma or from pathological thinning, is mainly based on the use of allografts. ${ }^{1-6}$ Allograft implantation has become a well-established procedure. A well-known complicating effect is immunological rejection of donor corneal tissue. Particularly, patients suffering from rheumatoid arthritis are at high risk. A strategy to prevent rejection is to down-regulate the patient's immune system prior to implantation. This approach may require a method for temporary closure of the corneal perforation. ${ }^{7.18}$ Recently, Nuijts et al. reported that NeuroPatch ${ }^{\oplus}$ is a suitable polymeric biomaterial for this purpose. ${ }^{19}$ NeuroPatch ${ }^{\otimes}$ is a polyurethane mesh with excellent biocompatibility; the material allows ingrowth of stromal fibroblast which deposit matrix material into the NeuroPatch pores and cavities. In this way, the implant integrates with the (healthy) surrounding corneal tissue. The major drawback of NeuroPatch ${ }^{\mathbb{}}$ is its non-transparency. Consequently, vision of the patient can be severely impaired, at least until the allograft is implanted.

In an attempt to develop a biomaterial that combines the advantages of NeuroPatch ${ }^{\oplus}$ with optical transparency, new biomaterials have been developed, which have to combine the advantages of NeuroPatch ${ }^{\text {w }}$ with optical transparency. ${ }^{20}$ The biomaterial of choice needs to meet a number of stringent requirements: (i), good biocompatibility; (ii), high transparency; (iii), adequate physical and mechanical properties (with respect to the sutureability and flexibility); (iv), some water uptake, which is accompanied by little or no swelling; (v), good interaction between the artificial implant and the host cornea, in order to allow epithelial coverage, and spreading of an even tear film; (vi), ingrowth of stromal fibroblasts with maintained corneal phenotype.

A study on copolymeric biomaterials, which are built up from a mixture of hydrophilic and hydrophobic monomers in a free radical polymerization reaction was conducted. By using this combination, the hydrophilicity of these materials can be controlled accurately. n-Butyl methacrylate (BMA) was chosen as the 
hydrophobic component. Different experiences from previous work guided in selecting a hydrophilic monomer for the formulation of the copolymers:

- using $\mathrm{N}, \mathrm{N}$-dimethylaminoethyl methacrylate affords homogeneous polymeric systems which unfortunately are cytotoxic due to the basicity of the pending $\mathrm{N}(\mathrm{Me})_{2}$ groups. ${ }^{21,22}$

- using 2-hydroxyethyl methacrylate (HEMA) results in copolymers with moderate hydrophilicity and mechanical properties which are not suitable for the intended application.

Based on these considerations hexaethyleneglycol methacrylate (HEGMA) has been selected as the hydrophilic building block (Figure 5.1). HEGMA contains 6 ethyleneoxide moieties and is therefore more hydrophilic than HEMA.

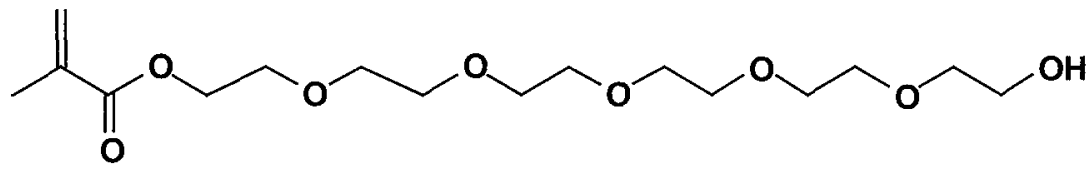

Figure 5.1: Structural formula of HEGMA.

The present work was conducted to investigate copolymers of BMA and HEGMA in more detail. This chapter describes: (i), NMR measurements on the copolymerization reaction BMA + HEGMA; (ii), analysis of the physico-chemical properties (molecular-weight distribution, glass transition temperatures, transparency, contact angles, thermal gravimetric analysis, fourier transform infrared spectroscopy (FT-IR), and nuclear magnetic resonance (NMR) microimaging experiments (swelling, water uptake)); (iii), experiments on protein adhesion using X-ray photo-electron spectroscopy (XPS) and matrix-assisted Laser Desorption Ionization time of flight (MALDI-TOF) mass spectrometry. ${ }^{23.24}$ Furthermore, the cytotoxicity and biocompatibility of the four copolymers, and poly(BMA), were tested in vitro. 


\subsection{Experimental section}

\subsubsection{Materials}

\section{a) Chemicals}

All solvents and starting reagents were of the highest purity available, or purified as specified. All solvents and reagents were purchased from Acros ('sHertogenbosch, The Netherlands). Commercial BMA was distilled under reduced pressure, in a batch of approximately $500 \mathrm{~mL}$; a prerun of approximately $50 \mathrm{~mL}$ was discarded. The main fraction was collected and stored at $-18{ }^{\circ} \mathrm{C}$. Commercial HEGMA was dissolved in chloroform, and passed through a column packed with inhibitor remover. Chloroform was removed under reduced pressure. The residue, a colorless viscous oil, was analyzed with two different techniques, i.e. ${ }^{1} \mathrm{H}$ NMR spectroscopy and fast-atom bombardment mass spectrometry (FAB-MS), in order to establish its purity and identity. ${ }^{1} \mathrm{H}$ NMR revealed the absence of solvent residues. FAB-MS showed the presence of the HEGMA monomer, but also the presence of the bifunctional (dimethacrylate) counterpart. The relative amount of the dimethacrylate was, approximately, $10 \mathrm{~mol} \%$. The material was stored at $-18^{\circ} \mathrm{C}$. Lysozyme grade 1 from chicken egg white was purchased from Sigma-Aldrich Chemie BV (Zwijndrecht, The Netherlands).

Dulbecco's modification of Eagle's medium/F12 nutrient mix containing GlutamaxI, Iscoves Modified Dulbecco's Medium, 10\% Fetal Calf Serum, penicillin, streptomycin and ITS-A (Insuline, Transferrin, Selenite) were purchased from Life Technologies (Breda, The Netherlands). NU-serum IV was purchased from Micronic B.V. (Lelystad, The Netherlands). Millicell - CM inserts were obtained from Millipore (Etten-Leur, The Netherlands) and (4, 5 dimethylthiazol-2yl)-2, 5diphenyl-2H-tetrazolium bromide (MTT) was purchased from Sigma/Aldrich. Human donor corneas were obtained from the Corneabank in Amsterdam (The Netherlands). 
Four different (co)polymers were prepared: A: poly(BMA); B: copolymer of HEGMA (10 $\mathrm{mol} \%$ ) and BMA ( $90 \mathrm{~mol} \%$ ); C: copolymer of HEGMA (20 $\mathrm{mol} \%$ ) and BMA ( $80 \mathrm{~mol} \%)$; and D: copolymer of HEGMA (25 mol \%) and BMA (75 $\mathrm{mol} \%$ ).

\section{b) Preparation of (co)polymers}

All materials were prepared according to the following procedure: HEGMA and BMA were mixed in the appropriate ratios, such that approximately 10 grams of monomer mixture was obtained in each case. Benzoyl peroxide $(0.2 \mathrm{~mol} \%)$ was used as radical initiator. The mixtures were homogenized in an ultrasonic bath for 5 minutes, and then transferred into Teflon ${ }^{\otimes}$ tubes (internal diameter $=8$ or $12 \mathrm{~mm}$, wall thickness $=1 \mathrm{~mm}$, length $=20 \mathrm{~cm}$ ), which were closed on one end with a glassstopper. The tubes were placed in an oil bath, which was coupled to a time/temperature control system. The time-temperature profile shown in Figure 5.2 was then run. ${ }^{25}$ Thermal (co)polymerizations afforded transparent polymeric rods. The rods were cut into discs with a diameter of 8 or $12 \mathrm{~mm}$ and a thickness of 0.5 $1.0 \mathrm{~mm}$. The discs obtained smooth surfaces.

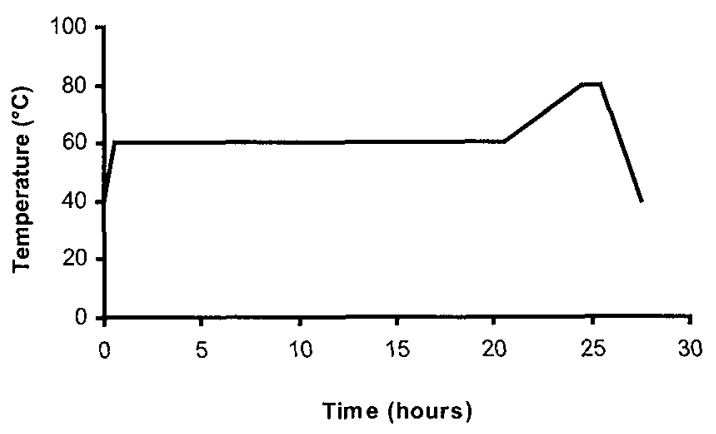

Figure 5.2: Time/temperature profile used during preparation of all materials. 


\subsubsection{Physico-chemical analysis}

\section{a) ${ }^{1} \mathrm{H}$ NMR analysis}

${ }^{1} \mathrm{H}$ NMR spectra were recorded at $399.9 \mathrm{MHz}$, on a Varian Unity-Plus NMR spectrometer. Deuterated dimethylsulfoxide (DMSO- $\mathrm{d}_{6}$ ) was used as the solvent. Tetramethylsilane was used as the internal standard $(\delta=0.00 \mathrm{ppm})$. This technique was used to investigate: (i), the residual monomer content of the (co)polymers; and (ii), the copolymerization of HEGMA and BMA.

Ad (i): A solution of hydroquinone (10.7 mg) in $4 \mathrm{~mL}$ of DMSO- $\mathrm{d}_{6}$ was made. This solution was split into four equal parts. In each solution a different material (A - D; $200 \mathrm{mg})$ was introduced. After 1 week, samples of the supernatants $(0.3 \mathrm{~mL})$ were mixed with pure DMSO-d 6 (0.3 mL), and transferred into 5-mm NMR sample tubes. ${ }^{1} \mathrm{H}$ NMR spectra were then run.

Ad (ii): Copolymerization reactions of BMA and HEGMA were monitored using ${ }^{1} \mathrm{H}$ NMR in such a way that the reactions were run inside a 5-mm NMR tube, and inside the NMR magnet. The monomers were dissolved in DMSO- $\mathrm{d}_{6}$, and the reaction was run at a temperature of $75{ }^{\circ} \mathrm{C}$, which led to approximately $75 \%$ conversion in approximately $1 \mathrm{~h}$. Three different mixtures of HEGMA and BMA were prepared; The mixtures contained 21.9, 37.7, and 61.7 mol \% HEGMA. 2,2'Azobis(2-methyl-propionitrile) (AIBN) was used as the radical initiator. The monomer mixtures $(0.1 \mathrm{~mL})$ were each dissolved in $0.6 \mathrm{~mL}$ of the following mixture; DMSO-d 6 (3 mL), AIBN (29.2 mg), and toluene (internal standard) (0.05 $\mathrm{mL})$, homogenized and transferred into a sample tube. At regular time intervals a spectrum was recorded and stored. The conversion was calculated from the ratio $\left(I_{H}\right.$ $\left.+I_{B}\right) / I_{T}$. This ratio is inversely proportional to the conversion. This means that $\left(I_{H}+\right.$ $\left.I_{B}\right) / I_{T}$ at $\mathbf{t}=0$ corresponds with $0 \%$ conversion and that $\left(I_{H}+I_{B}\right) / I_{T}=0$ corresponds with a $100 \%$ conversion.

$I_{H}=\quad$ integral of the olefinic protons of unreacted HEGMA $(\delta=6.04$ and $5.66 \mathrm{ppm})$ 
$I_{\mathrm{B}}=\quad$ integral of the olefinic protons of unreacted BMA $(\delta=6.01$ and 5.64 ppm)

$I_{T}=$ integral of the aromatic protons of the internal standard, toluene, $(\delta=7.3-7.1 \mathrm{ppm})$

The fraction of unreacted HEGMA during the reaction was calculated with the following equation:

Fraction unreacted HEGMA $=I_{H} /\left(I_{H}+I_{B}\right)$

\section{b) Optical transmittance}

Optical transmittance of materials A - C was measured at the wavelengths 543 and $633 \mathrm{~nm} .{ }^{26}$ HeNe-lasers were used as the light source. Specimens were made in the form of cylindrical rods (length $=100 \mathrm{~mm}$, diameter $=8 \mathrm{~mm}$ ). The lasers emitted light along the long axis of the circular rods. Light intensities were measured with a radiometer (Edgarton, Gesmeshausen \& Grier model 580 radiometer with a narrow beam adapter model 580-32). Thin glass plates were glued to the ends of the rods, using methylcellulose. In this way smooth surfaces were obtained, and scattering was avoided.

The measurements were corrected for the intensity loss caused by two glass plates glued together with methylcellulose. The transmittance $(T)$ of a $1 \mathrm{~mm}$ sheet of material was determined.

\section{c) Wilhelmy contact angle measurements}

The Wilhelmy plate technique was used to determine advancing and receding water contact angles of the materials. All measurements were performed at $20^{\circ} \mathrm{C}$ in double distilled water. The receding contact angle was determined in the second run. 


\section{d) Differential scanning calorimetry (DSC)}

DSC measurements were performed on a Perkin Elmer Differential Scanning Calorimeter Pyris 1. Nitrogen was used as the carrier gas. Calibration was performed with gallium and indium. Glass-transition temperatures $(\mathrm{Tg})$ were taken as the midpoint of the transition region. The samples were heated from -50 to $90^{\circ} \mathrm{C}$ at a heating rate of $10 \mathrm{deg} . / \mathrm{min}$.

\section{e) Thermal gravimetic analysis (TGA)}

Thermal degradation of all materials was analyzed with a Perkin Elmer TGA-7 thermogravimetric analyzer (Perkin Elmer, Eden Prairie, MN, USA) at a heating rate of $10 \mathrm{deg} . / \mathrm{min}$. The degradation temperature was taken as the temperature at 2 $\%$ weightloss. The samples were run from room temperature up to $300^{\circ} \mathrm{C}$.

\section{f) NMR microimaging}

MRI was performed with a Varian Unity-Plus system, comprising a super-cooled wide-bore magnet $(89 \mathrm{~mm}$ ) operating at a magnetic field strength of 9.4 Tesla (corresponding with a proton frequency of $400 \mathrm{MHz}$ ). The gradient coil, as well as the microimaging probe, were manufactured by the Fraunhofer Institute (Ingelheim, Germany). The gradient coil is capable of generating a maximum magnetic-field gradient of 50 Gauss $/ \mathrm{cm}$. The microimaging probe was equipped with an insert with a cylindrical sample-space (diameter: $25 \mathrm{~mm}$, effective height: approximately $20 \mathrm{~mm}$ ).

A cylindrical bar of material D (diameter: $8 \mathrm{~mm}$, length: $6 \mathrm{~mm}$ ) was placed centrally and vertically in a glass tube (outer diameter $23 \mathrm{~mm}$, inner diameter $21 \mathrm{~mm}$, length approximately $8 \mathrm{~cm}$ ). The tube was filled with distilled water, and the sample was placed inside the microimaging probe. The sample temperature was controlled via a thermocouple/heater system, and maintained at $22{ }^{\circ} \mathrm{C}$ throughout all imaging experiments.

After initial homogenization of the magnetic field, five transverse slices of $300 \mu \mathrm{m}$ thickness and a center-to-center gap of $0.5 \mathrm{~mm}$ were acquired. A $512 \times 512$ matrix spin-echo sequence (SEMS) was used; this resulted in a pixel size of $31 \times 31 \mu \mathrm{m}$. A 
signal averaging of 8 , and a relaxation time of $4 \mathrm{sec}$. was used. The total aquisition time for 5 slices was $2 \mathrm{~h}, 16 \mathrm{~min}$, and $56 \mathrm{sec}$. The water penetration was monitored regularly during 2 weeks. Influx of water was monitored in the middle of the polymeric bar; accumulation of water in this section is entirely due to radial diffusion. Images were measured and stored at regular time intervals.

\section{g) Water uptake of the (co)polymers}

Water uptake was characterized as follows. Three discs of materials A - C were weighed in dry form. Subsequently, the specimens were incubated in a phosphate buffered saline (PBS) solution at $37^{\circ} \mathrm{C}$. At regular time intervals all the discs were removed from the PBS solution. Water present on the surfaces of the discs was removed and the samples were re-weighed. The percentage of water uptake was calculated with the following equation.

Water uptake $=\left(\left(\mathrm{M}_{\mathrm{t}=\mathrm{x}}-\mathrm{M}_{\mathrm{t}=0}\right) / \mathrm{M}_{\mathrm{t}=0}\right) * 100 \%$

$\mathrm{M}_{\mathrm{t}=\mathrm{x}}=$ Mass of the specimen after incubation in the PBS solution

$\mathrm{M}_{\mathrm{t}=0} \quad=\quad$ Mass of the dry specimen

\section{h) Fast atom bombardments mass spectroscopy (FAB-MS)}

FAB-MS was carried out with a JEOL JMS SX/SX102A four-sector mass spectrometer, coupled to a JEOL MS/MP7000 data system. The sample was loaded in a matrix solution (glycerol, thioglycerol or nitrobenzylalcohol) onto a stainless steel probe and bombarded with xenon atoms with an energy of $3 \mathrm{keV}$. During the high resolution FAB-MS measurements a resolving power of $10,000(10 \%$ valley definition) was used. Cesiumiodide, glycerol or polyethylene oxide $\left(\mathrm{M}_{\mathrm{W}, \mathrm{av}}=600\right)$ was used to calibrate the mass spectrometer.

\section{i) Gel permeation chromatography (GPC)}

GPC was carried out using a WATERS Model 510 pump, Model 486 UV detector (at $254 \mathrm{~nm}$ ), and Model 410 refractive index detector (at $40^{\circ} \mathrm{C}$ ). Injections of the polymer solution $(1 \mathrm{mg} / \mathrm{mL})$ were performed by a WATERS Model WISP 712 
autoinjector, and the injection volume used was $50 \mu \mathrm{L}$. The columns used were : (i), A PLgel guard ( $5 \mu \mathrm{m}$ particles) $50 * 7.5 \mathrm{~mm}$ guard column, followed by 2 PLgel mixed-C ( $5 \mu \mathrm{m}$ particles) $300 * 7.5 \mathrm{~mm}$ columns $\left(40^{\circ} \mathrm{C}\right.$ ) in series (referred to as the standard column set); or (ii), a PLgel guard (5 $\mu \mathrm{m}$ particles) $50 * 7.5 \mathrm{~mm}$ precolumn, followed by 2 PLgel columns in series of $500 \AA$ ( $5 \mu \mathrm{m}$ particles) and $100 \AA$ ( $5 \mu \mathrm{m}$ particles) respectively (the low molecular weight set). Tetrahydrofuran (Biosolve, stabilized with BHT) was used as eluent at a flow rate of $1.0 \mathrm{~mL} / \mathrm{min}$. Calibration was performed with polystyrene standards (Polymer Laboratories, $M=580-7.1$ * $\left.10^{6}\right)$. Data acquisition and processing were performed using WATERS Millennium 32 (v3.05) software.

\subsubsection{Evaluation of protein adsorption onto polymeric materials}

\section{a) Incubation of polymers}

Protein adsorption onto materials A - C was studied with lysozyme. The protein (20 $\mathrm{mg}$ ) was dissolved in PBS (20 mL). Three discs (diameter $12 \mathrm{~mm}$, height $1 \mathrm{~mm}$ ) of each material, were incubated separately in $1.5 \mathrm{~mL}$ of the protein solution at $37^{\circ} \mathrm{C}$ for $24 \mathrm{~h}$. After the incubation the samples were washed thoroughly with distilled water, in order to remove loosely bound material. The samples were allowed to dry under atmospheric conditions. The dried samples were then analyzed by means of MALDI-TOF mass spectrometry or XPS.

\section{b) MALDI-TOF analysis of polymeric surfaces}

MALDI-TOF experiments were performed essentially as described by Kingshott et al. ${ }^{9-10} \mathrm{~A}$ Bruker Biflex ${ }^{\mathrm{TM}}$ III instrument was used in the linear mode with a pulsed $\mathrm{N}_{2}$ laser ( $\delta=337 \mathrm{~nm}, 3 \mathrm{~ns}$ pulse width). After incubation of materials $\mathrm{A}-\mathrm{C}$ in the protein solution and rinsing off the loosely bond proteins, the matrix solution was applied onto small parts of the polymer surfaces and they were dried in a fume hood. The matrix solution consisted of $20 \mathrm{mg} / \mathrm{mL}$ sinapinic acid (Sigma) in 2:1 water : acetonitrile containing $0.1 \%$ trifluoroacetic acid (TFA). The samples were fixed to the sample stub using double-sided tape. The matrix crystals that form on 
the sample are then irradiated by the pulsed UV laser, subsequently the protein is ionized, extracted, and detected in the standard MALDI-TOF mass spectroscopic manner using a time of flight detector. During analysis the laser power was adjusted to maximize the signal intensity and resolution, and data was acquired. Calibration was performed externally using the known molecular weight of the protein. Sample analysis was performed using the Scout sample manipulator that allows for two-dimensional adjustment of the laser position. This parameter was occasionally required to locate matrix crystals with higher concentrations of protein that occur as a result of inhomogeneous drying and crystallization.

\section{c) XPS analysis of polymeric surfaces}

XPS analysis of the samples was conducted with a Leybold MAX200 XPS instrument. Sample areas of $7 * 4 \mathrm{~mm}^{2}$ were analyzed. $\mathrm{Mg} \mathrm{K} \alpha(1253.6 \mathrm{eV})$ radiation of a $\mathrm{Mg} / \mathrm{Al}$ double-anode X-ray tube $(13 \mathrm{kV}, 20 \mathrm{~mA})$ was used. Calibration of the spectrometer was performed with $\mathrm{Ag}, \mathrm{Cu}$ and $\mathrm{Au}$. At the used pass energy of 48 $\mathrm{eV}$, the full width at half-maximum for $\mathrm{Ag} 3 \mathrm{~d} 5 / 2$ was $0.92 \mathrm{eV}$. The base pressure in the analysis chamber was well below $1 * 10^{-9}$ mbar. A Sun Sparcstation 5 , and a SpecsLab (F. Specs Berlin) data system were used to control the instrument, for data acquisition and analysis. For the quantative analysis the spectra were corrected for the analyzer transmission function and concentrations were obtained from the integrated intensities by using calculated sensitivity, using the approach of Nöller $e t$ $a l$. and the Scofield cross sections. ${ }^{27,28}$ For energy referencing a $C 1$ s binding energy of $284.8 \mathrm{eV}$ for aliphatic carbon was used. The samples were measured at the usual $90^{\circ}$ take-off angle. 


\subsubsection{Evaluation of the biocompatibility}

\section{a) MTT assay}

Samples of materials A - D were sterilized with $70 \%$ ethanol and subsequently rinsed three times with sterile PBS. All experiments were performed in 4-fold; the samples were prepared by cutting the circular discs of each material (vide supra) in four equal segments. Mouse fibroblasts (3T3 cells) were incubated in a 24-wells tissue culture polystyrene (TCP) plates at a density of approximately $10^{4}$ cells/well in culture medium $(500 \mu \mathrm{L})$. Culture medium was Dulbecco's modification of Eagle's medium/F12 nutrient mix containing Glutamax-I and supplemented with $10 \%$ NU-serum (IV) and $25 \mu \mathrm{g} / \mathrm{mL}$ ascorbic acid. Cells were cultured in an incubator at $37{ }^{\circ} \mathrm{C}$ and $5 \% \mathrm{CO}_{2}$ overnight. Then Millicell - CM inserts, containing the materials, were placed in the wells, and $500 \mu \mathrm{L}$ culture medium was added. Cells were cultured for another 3 days. The inserts were then removed, and the culture medium was replaced with culture medium containing MTT, ( $300 \mu \mathrm{g} / \mathrm{mL})$.

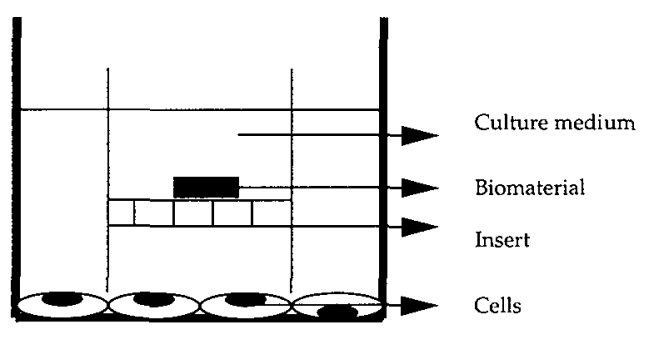

Figure 5.3: Experimental setup of the MTT assay.

Cells were cultured for another $4 \mathrm{~h}$. Then the medium was discarded and the precipitated formazan dissolved in DMSO $(200 \mu \mathrm{L})$. Aliquots of $60 \mu \mathrm{L}$ of each sample were transferred into a microtiter plate and the absorbance at $540 \mathrm{~nm}$ was measured on a microplate reader. The experimental setup is schematically represented in Figure 5.3. Note that two reference materials were included in the 
test; these were inserts without biomaterial as a negative control and latex (cytotoxic) as a positive control.

\section{b) Cell culture experiment}

The experiments were performed in 4-fold with materials A - C. Samples were prepared by cutting the circular discs of each material (vide supra) in four equal segments. These materials were incubated for 3 weeks at $37{ }^{\circ} \mathrm{C}$ in PBS. Epithelial cellular outgrowths of corneal rim biopsies obtained from human donor corneas, were grown together with materials A - C for 3 weeks. The cells were cultured in Iscoves Modified Dulbecco's Medium, supplemented with $5 \%$ Fetal Calf Serum, penicillin $(100 \mathrm{U} / \mathrm{mL})$, streptomycin $(100 \mathrm{mg} / \mathrm{mL})$, epidermal growth factor, and ITS-A. Cell culturing was performed at $37{ }^{\circ} \mathrm{C}$ in an incubator and at $5 \% \mathrm{CO}_{2}$. Medium was changed twice a week. At the end of the incubation period, the epithelial cellular outgrowth together with the material samples were fixed for $2 \mathrm{~h}$ with $4 \%$ glutaraldehyde solution in PBS, and stained with hematoxylin or methylene blue. Four wells served as a control series; no biomaterial was placed in these wells. Photographs of the different materials were taken on a phase contrast microscope.

\subsection{Results and discussion}

\subsubsection{Preparation and physico-chemical analysis of materials A - D}

\section{a) DSC and TGA analysis of the prepared materials}

Glassy transparent rods were obtained after each synthesis. It proved to be easy to remove the polymeric rods from the Teflon ${ }^{\circledR}$ tubes. The rods could be processed further into circular discs by cutting with a microtome at room temperature.

The Tg-values measured for materials $\mathrm{A}-\mathrm{C}$ were $38^{\circ} \mathrm{C}, 28^{\circ} \mathrm{C}$, and $17^{\circ} \mathrm{C}$, respectively. At room temperature, material $\mathrm{C}$ proved to be rubbery and flexible, 
whereas poly(BMA) was more rigid. It is clear that incorporation of more HEGMA leads to a decrease of $\mathrm{Tg}$, and thus results in an increase of flexibility. It is likely that this effect will be more pronounced when the materials are in contact with water. Water molecules penetrating the material will act as a plasticizer.

TGA measurements revealed that materials $\mathrm{A}$ - $\mathrm{D}$ are stable for temperatures up to $210^{\circ} \mathrm{C}$ (data not shown). This implies that the materials are thermally stable at 37 ${ }^{\circ} \mathrm{C}$.

\section{b) ${ }^{1} \mathrm{H}$ NMR analysis of the copolymerization of HEGMA and BMA}

Copolymerizations of BMA and HEGMA were monitored via ${ }^{1} \mathrm{H}$ NMR spectroscopy, in analogy with previous work on: (i), the copolymerization of methyl methacrylate or HEMA with iodine-containing methacrylates; or (ii), the copolymerization reaction of $\mathrm{N}, \mathrm{N}$-dimethylaminoethyl methacrylate + HEMA and 1-vinyl-2-pyrrolidinone + HEMA. ${ }^{21,29}$ In the case of the reaction BMA + HEGMA, it was found that the ${ }^{1} \mathrm{H}$ NMR signals of the polymeric products show tremendous overlap. Therefore, we had to confine the analysis of the reaction to monitoring the signals of the olefinic protons of both monomers, which are clearly discernible and isolated in the spectral region $\delta 6.1-5.6 \mathrm{ppm}$ (Figure 5.4). Two essential parameters can be derived quickly and accurately from these signals: (i), the conversion; and (ii), the molar ratio of the unreacted monomers.

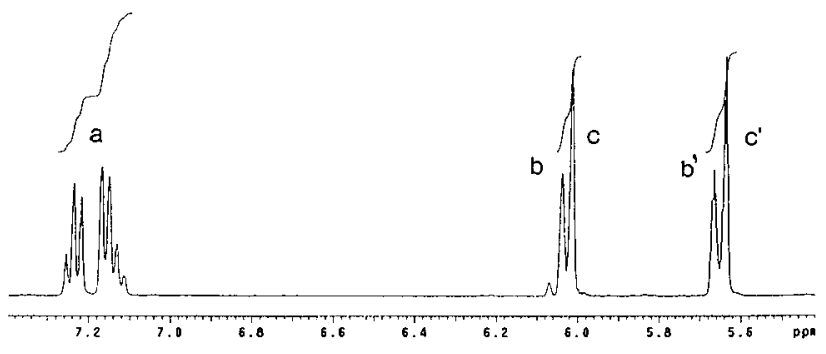

Figure 5.4: A typical 'H NMR spectrum of the monomer mixtures; (a) peaks corresponding to the aromatic protons of toluene; $(b)$ and $\left(b^{\prime}\right)$ peaks corresponding to the olefinic protons of HEGMA; $(c)$ and $\left(c^{\prime}\right)$ peaks corresponding to the olefinic protons of $B M A$. 
Ad (i): To calculate the conversion a reference was added to the reaction mixture: this reference was toluene, of which the aromatic protons resonate at $\delta 7.3-7.1 \mathrm{ppm}$ (Figure 5.4). The ratio of the integrals $\delta(6.1-5.6)$ and $\delta(7.3-7.1)$ drops linearly with the conversion of the polymerization reaction.

Ad (ii): The olefinic protons appear in 2 groups of 2 singlets in the spectrum. The left peaks $(\delta=6.04$ and $5.66 \mathrm{ppm})$ and the right peaks $(\delta=6.01$ and $5.64 \mathrm{ppm})$ belong to HEGMA and BMA, respectively. It was possible to obtain accurate integrals of the individual resonances. In this way, we could monitor quantitatively whether or not one of the monomers is converted preferentially over the other.

Three different starting compositions were used (mol percentages): (i), BMA : HEGMA = $78.1: 21.9$; (ii), BMA : HEGMA = 62.3 : 37.7; and (iii), BMA : HEGMA 38.3 : 61.7. The copolymerizations proceeded smoothly and conversions $>75 \%$ were reached within $1 \mathrm{~h}$. Since data acquisition is fast $(<1 \mathrm{~min}$.) and signal/noise ratios were high, it was possible to monitor the reactions in detail. Table 5.1 summarizes the results of these experiments (see Figure 5.5). It can be concluded

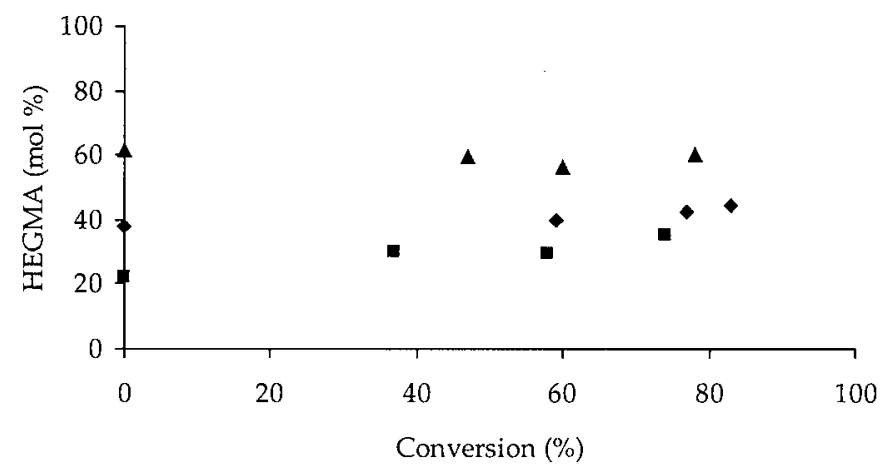

Figure 5.5: Graph of HEGMA content in the feed during the copolymerization with BMA. Monomer mixture with initial HEGMA content of $61.7(\mathbf{\Delta}), 37.7(\bullet)$ and $21.9(\mathbf{\square}) \mathrm{mol} \%$. 
Table 5.1: Compilation of the 'H NMR Results.

\begin{tabular}{|c|c|c|}
\hline Reaction time (min.) & Conversion (\%) & HEGMA content in the feed (mol \%) \\
\hline 0 & 0 & 21.9 \\
\hline 20 & 37 & 29.9 \\
\hline 40 & 58 & 29.3 \\
\hline 60 & 74 & 35.5 \\
\hline 0 & 0 & 37.7 \\
\hline 20 & 59 & 39.8 \\
\hline 40 & 77 & 42.3 \\
\hline 60 & 83 & 46.3 \\
\hline 0 & 0 & 61.7 \\
\hline 20 & 47 & 59.2 \\
\hline 40 & 60 & 56.5 \\
\hline 60 & 78 & 62.0 \\
\hline
\end{tabular}

from the three series of data, that the relative contents of the free monomers remain approximately constant as the conversion increases. This indicates that both monomers have approximately equal reactivities. Hence, it is expected that the copolymerizations afford random-type copolymers of the type ...AABABAABA... Note, that the relative content of HEGMA increases slightly when conversions are high, typically $>70 \%$. This indicates that BMA is then consumed slightly faster than HEGMA. A possible explanation is that diffusion limitation, hampers the larger HEGMA molecules more than the BMA molecules to reach the reactive center of the growing polymer chains at high conversion.

\section{c) ${ }^{1} \mathrm{H}$ NMR analysis of residual monomer content}

Materials A - D showed extensive swelling, but no dissolution in DMSO- $\mathrm{d}_{6}$. The same observation was made for a variety of other organic solvents. This is in good agreement with the fact that the bifunctional HEGMA counterpart, a crosslinker, is present in the materials. Copolymerization therefore renders insoluble materials. 
This precluded the recording of proton NMR spectra, and also GPC (vide infra). The supernatant was subjected to ${ }^{1} \mathrm{H}$ NMR analysis after one week of incubation. There were no detectable quantities of residual monomer. This confirms the idea that high conversions were reached during the polymerizations.

\section{d) FT-IR analysis}

Figure 5.6 shows a FT-IR spectrum of material C. The regions of interest are $1680-$ $1480 \mathrm{~cm}^{-1}$ (olefinic group stretch-vibrations), and $3400-3230 \mathrm{~cm}^{-1}$ (hydroxyl stretchvibrations). The spectrum clearly reveals the absence of olefins. Thus, FT-IR and ${ }^{1} \mathrm{H}$ NMR both show that the materials are essentially free of residual monomer. Note, the presence of a weak and broad hydroxyl peak. The hydroxyl peak increases in the series of materials $A-D$, which is in agreement with the increasing content of HEGMA.

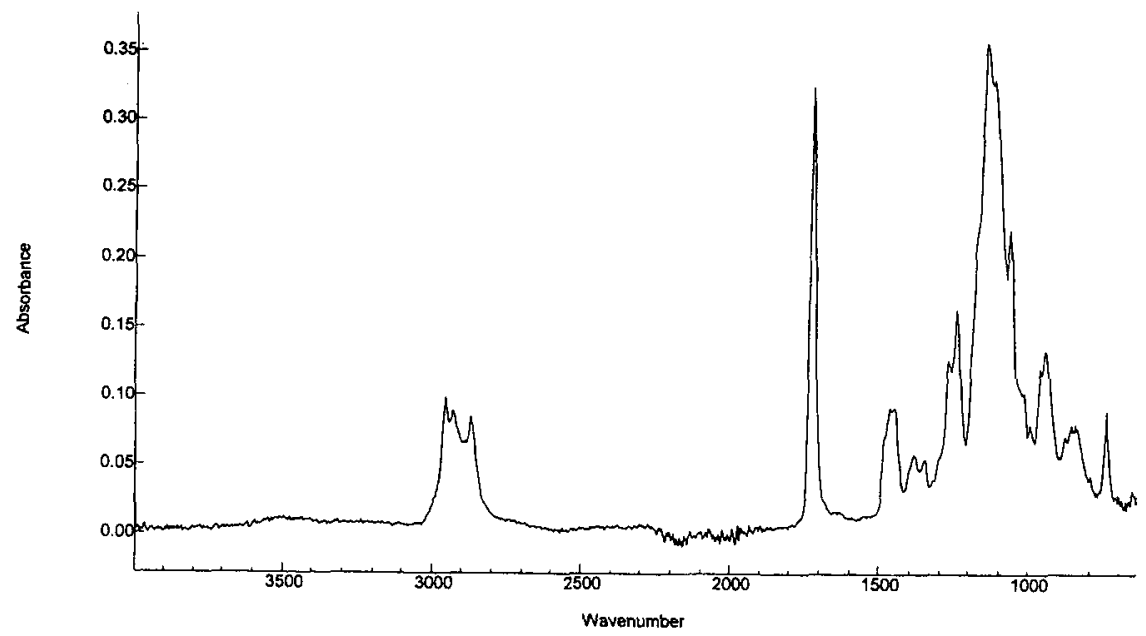

Figure 5.6: FT-IR spectrum of material C. 


\section{e) Contact angle measurements}

Table 5.2 shows the results of these experiments. The data confirm that the incorporation of more HEGMA leads to a more hydrophilic material. This effect was consistently observed for different batches and after different repetitions of the experiment. Another remarkable point is that, for materials A - D a large difference is found between the receding and the advancing contact angles. This may indicate that the surface layer of these materials responds to immersion of the material in water, probably by moving the pending hexaethyleneglycol chains outwards. This rearrangement is not yet complete during the measuring of the advancing contact angle; the receding contact angle is measured in the equilibrium situation.

Table 5.2: Contact Angles of Materials $A-D$.

\begin{tabular}{|c|c|c|}
\hline Material & Receding $\left(^{\circ}\right)$ & Advancing $\left(^{\circ}\right)$ \\
\hline A & 50.9 & 81.4 \\
\hline B & 46.0 & 94.2 \\
\hline C & 38.8 & 81.0 \\
\hline D & 20.8 & 109.6 \\
\hline
\end{tabular}

\section{f) Optical transmittance}

The results of these measurements are given in Table 5.3. The transparency of the materials compares well with that of the cornea, which is 0.90 at $543 \mathrm{~nm}$, and 0.92 at $633 \mathrm{~nm}^{16}$

Table 5.3: Optical Transmittance of Materials A - C.

\begin{tabular}{|c|c|c|c|}
\hline $\begin{array}{c}\text { Wavelength } \\
(\mathrm{nm})\end{array}$ & Material A & Material B & Material C \\
\hline 633 & 0.91 & 0.91 & 0.92 \\
\hline 543 & 0.91 & 0.91 & 0.91 \\
\hline
\end{tabular}




\section{g) GPC analysis}

Material A readily dissolved in THF, and GPC revealed that the weight-averaged molecular weight $(\mathrm{Mw})$ was $>4 * 10^{6} \mathrm{~g} / \mathrm{mol}$. Attempts to characterize materials $B$ and $C$ further through GPC failed, since these materials were insoluble in a variety of organic solvents (dimethylsulfoxide, hexafluoroisopropanol, tetrachloroethane, trichlorobenzene, chloroform, tetrahydrofuran), even at high temperatures. The insolubility can be ascribed to the fact that materials $B$ and $C$ are three-dimensional materials due to the presence of a bifunctional HEGMA derivative (vide supra).

\section{h) NMR microimaging swelling experiments}

Figure 5.7 shows the penetration of water into a central slice of the rod of material D. The diffusion process was monitored during 2 weeks; Figure 5.7A marks the start of the experiment, while Figures 5.7B - 5.7D correspond to immersion times of $100 \mathrm{~h}, 200 \mathrm{~h}$ and $500 \mathrm{~h}$, respectively. Note that the water-free areas are black, since the proton density is low. Gray areas reveal the presence of water. The water boundary moved approximately $2 \mathrm{~mm}$ in the first $100 \mathrm{~h}$ (Figure 5.7B). After $200 \mathrm{~h}$, a small water-free area in the center can still be distinguished (Figure 5.7C). Figure 5.7D shows saturation of the specimen. This point of saturation was reached after $350 \mathrm{~h}$. After completion of the imaging experiment, the specimen was dried superficially and weighed. The specimen was then lyophilized and re-weighed. This revealed that the equilibrium water uptake is approximately $9 \%$ by weight. The images in Figure 5.7 also show that the water uptake does not lead to significant swelling; the geometry of the rod is virtually unchanged. We considered this of importance since swelling of the material, when used as a corneal implant, would be intolerable. It must be noted that the water uptake of materials $A-C$ proceeded very slowly, which precluded the use of MRI microimaging to characterize the diffusion. 

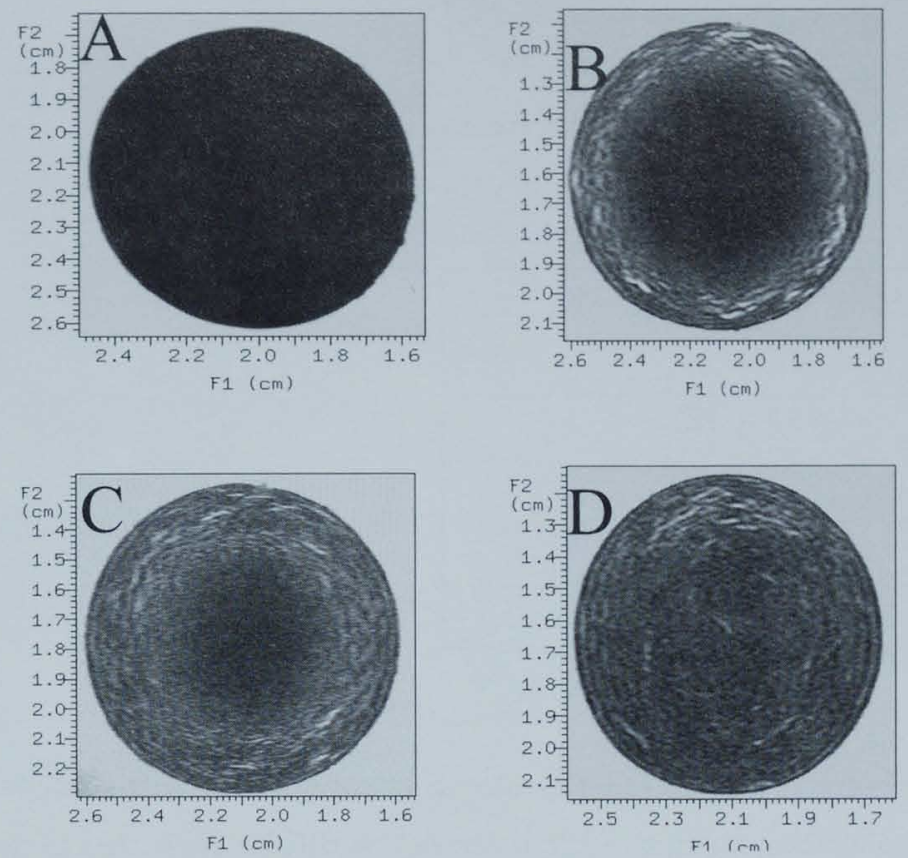

Figure 5.7: Penetration of water into a central slice of a rod of material $D ;(A)$ start of the experiment $t=$ $0 \mathrm{~h},(B)$ water-penetration after $100 \mathrm{~h}$, (C) water-penetration after $200 \mathrm{~h}$ and (D) water-penetration after $500 \mathrm{~h}$.

\section{i) Water uptake of materials A - C}

Materials A, B and D absorb water upon immersion in water (Table 5.4).

Material A absorbs a small amount of water compared to materials B and C, due to its hydrophobic nature.

Table 5.4: Water Uptake of Materials A - C.

\begin{tabular}{|c|c|}
\hline Materials & Water uptake (mass\%) (st.dev). \\
\hline A & $0.6(0.2)$ \\
\hline B & $3.6(0.3)$ \\
\hline C & $8.0(1.2)$ \\
\hline
\end{tabular}




\subsubsection{Cytotoxicity and biocompatibility of the polymeric materials}

\section{a) MTT assay}

Table 5.5 compiles the results of the MTT test for materials A - D.

Table 5.5: Viability of $3 T 3$ Cells in the Presence of Non-Incubated Samples of Materials A - D.

\begin{tabular}{|c|c|}
\hline Materials & $\begin{array}{c}\text { Cell Viability (\%), (st.dev) } \\
\text { incubation of } 0 \text { days }\end{array}$ \\
\hline A & $95.3(6.22)$ \\
\hline B & $71.4(8.0)$ \\
\hline C & $62.7(2.1)$ \\
\hline D & $67.7(4.6)$ \\
\hline
\end{tabular}

Unfortunately, materials B - D proved to be cytotoxic, in comparison with material A. We have no clear explanation for this result; it can not readily be attributed to the release of free monomer, since both FT-IR and ${ }^{1} \mathrm{H}$ NMR show that there is hardly any residual monomer present. An alternative explanation may be that cytotoxic oligomers or initiator remnants leach out of the materials. We decided therefore to wash the materials, prior to the MTT analysis, by incubating them in PBS at $37^{\circ} \mathrm{C}$. After 1, 2 and 3 weeks of incubation, the MTT assay was repeated for materials B D. This proved to be effective, provided that the samples were incubated for at least 1 week (Table 5.6). 
Table 5.6: Viability of Cells in Contact with Materials B - D, after Incubation for 1 Week.

\begin{tabular}{|c|c|}
\hline Materials & $\begin{array}{c}\text { CV (\%), (st.dev) } \\
\text { incubation of 1 week }\end{array}$ \\
\hline B & $99.6(7.0)$ \\
\hline C & $84.2(4.8)$ \\
\hline D & $89.8(4.3)$ \\
\hline
\end{tabular}

$\mathrm{CV}=$ cell viability, $\mathrm{SD}=$ standard deviation

\section{b) Cell culture experiments}

The setup of the experiments, which were designed to study the interaction between epithelial cells and the biomaterials, is schematically drawn in Figure 5.8. Figure 5.8X marks the start of the experiment. The circle represents a well in a 24well TCP plate. The biomaterial specimen (1) was placed in the well and the human corneal biopsy (2) was placed contra lateral. Figure 5.8Y shows the situation where cells have proliferated and migrated on the bottom of the well, but the frontier has not yet reached the biomaterial. In Figure 5.8Z, the cells have contacted the biomaterial, and their interaction with the biomaterial can be studied with phase contrast microscopy.

Figure 5.9 shows a phase contrast microscopic image of the epithelial cells in contact with material $\mathrm{B}$; this situation resembles Figure $5.8 \mathrm{Z}$. It is clear that the epithelial cells proliferate and migrate in the presence of the biomaterial. The cells 


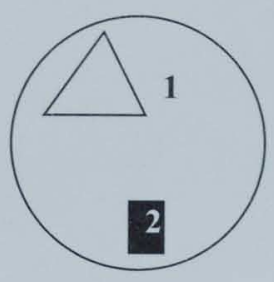

X

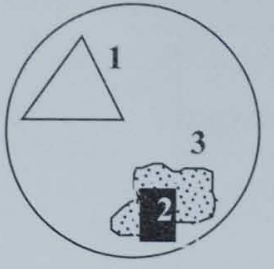

Y

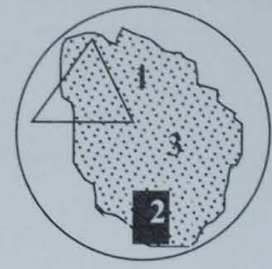

Z

Figure 5.8: Experimental setup of the epithelial cell proliferation and migration in the presence of

biomaterial. (X), the experimental setup; (1) the biomaterial, (2) the corneal biopsy; $(Y)$, the epithelial cell proliferation and migration (3) after a period of time; $(\mathrm{Z})$, the epithelial cells have reached the biomaterial.

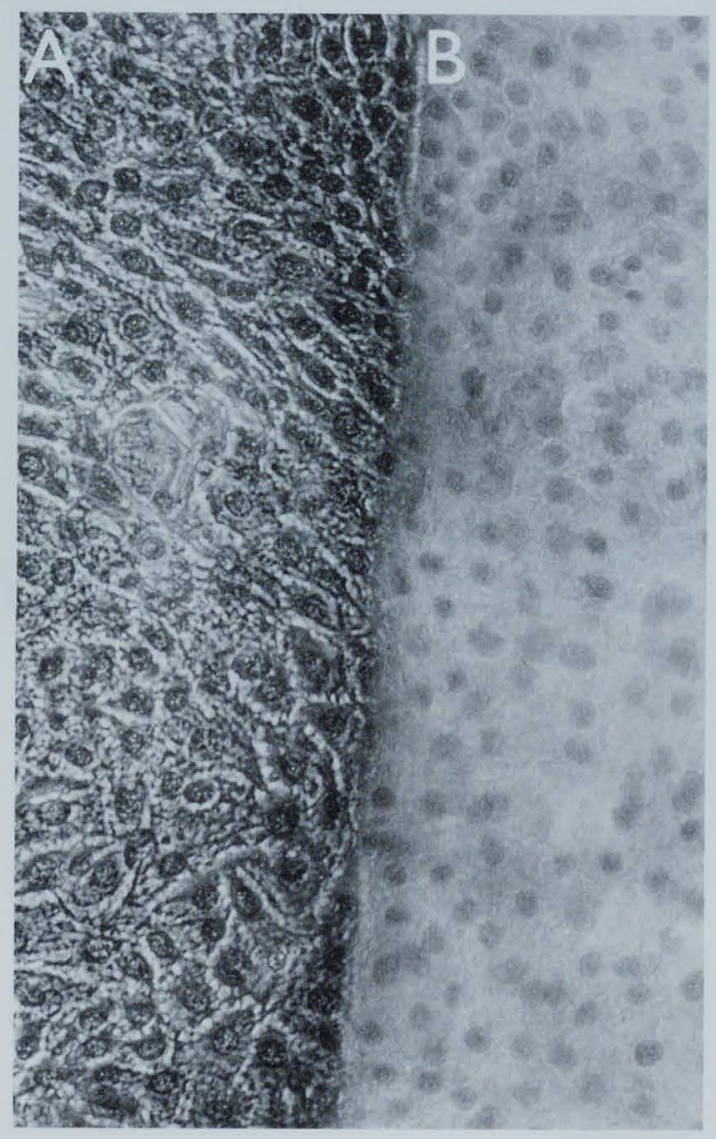

Figure 5.9: Phase contrast micrograph of epithelial cells in stage Z (viz. Figure 5.8). A: proliferated epithelial cells adhered to the TCP. B: nuclei of the epithelial cells in between TCP and the biomaterial specimen. 
grow underneath the specimen. Note that the biomaterial retains excellent optical transparency. Identical observations were made in analogous experiments using materials $\mathrm{A}$ and $\mathrm{C}$. We have not seen any ingrowth of epithelial cells into the materials, clearly this can be attributed to the non-porous nature of these materials.

\subsubsection{Adsorption of lysozyme onto the polymeric surfaces}

\section{a) MALDI-TOF and XPS analysis of surfaces exposed to lysozyme solutions}

Our studies on protein adsorption were focused on the protein lysozyme, which is known to play an important role in biofouling of contact lenses. Discs of materials A - C were immersed in a solution of lysozyme in PBS at $37^{\circ} \mathrm{C}$, for $24 \mathrm{~h}$. The presence of adsorbed protein was verified with MALDI-TOF and XPS. MALDI-TOF revealed the presence of adsorbed lysozyme on all three materials. This was most evident from the observation of two peaks in the mass spectrum at $\mathrm{m} / \mathrm{z}=14300$ and at $\mathrm{m} / \mathrm{z}=7100$. These peaks correspond with [lysozyme $+\mathrm{H}]^{+}$, and [lysozyme + $2 \mathrm{H}]^{2+}$, respectively. These data coincide with previous findings of Kingshott et al ${ }^{9 \cdot 10}$ It must be noted that MALDI-TOF provides merely qualitative information (the presence or the absence of the protein). The technique does not provide information on the surface density of adsorbed lysozyme. 


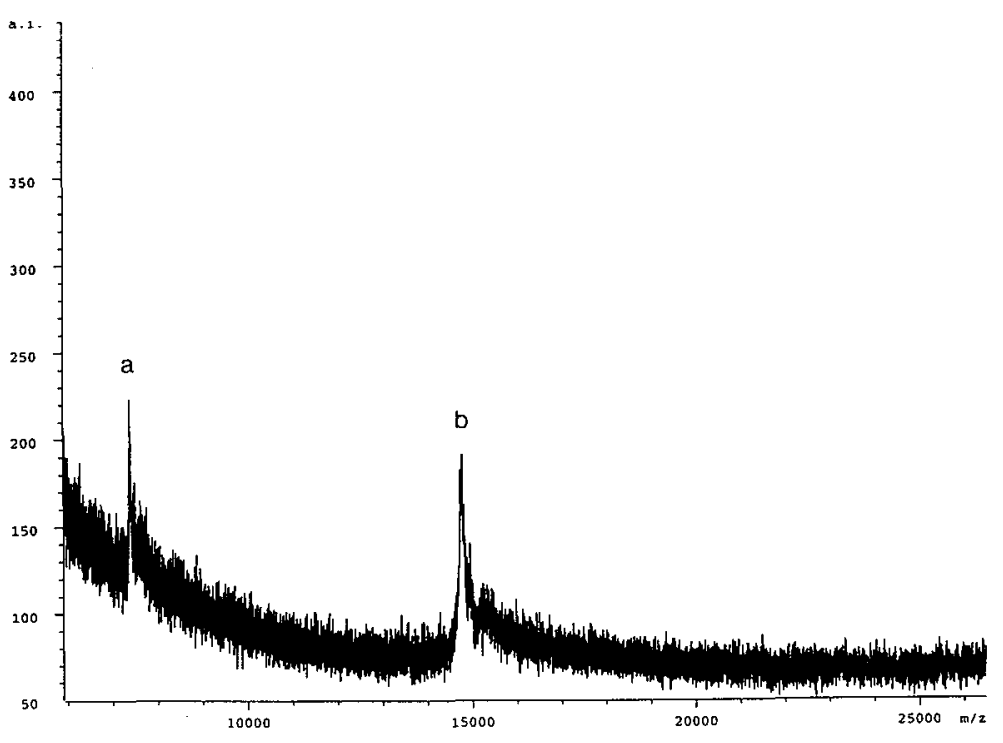

Figure 5.10: MALDI-TOF mass spectrum of lysozyme adsorbed onto material $\mathrm{C}$ after $24 \mathrm{~h}$ of incubation. (a) The doubly charged molecular ion $(M+2 H)^{2+}(7100 \mathrm{~m} / \mathrm{z})$; and $(b)$ the molecular ion plus one proton $(M+H)^{+}$ (14. $3100 \mathrm{M} / \mathrm{z}$ ) are detected.

Typically, Figure 5.10 shows the mass spectra measured for material $\mathrm{C}$, after incubation with lysozyme.

Protein adsorption was studied further with XPS, which allows detailed analysis of the atomic composition of material surfaces. In our case, the nitrogen content of the surface reveals the presence of lysozyme. The pure biomaterial is devoid of nitrogen, which was confirmed in a series of XPS spectra of the untreated materials A - C. Oxygen, carbon and nitrogen were detected on all incubated surfaces. The observed binding energies for the oxygen, nitrogen and carbon atoms are in good agreement with those of Beamson and Briggs. ${ }^{30}$ The spectra were analyzed by applying curve deconvolution, using a Gaussian line shape.

The compositions of the outermost surface layer of materials A - C, after incubation with lysozyme, are compiled in Table 5.7. 
Table 5.7: Surface Compositions of Materials A - C.

\begin{tabular}{|c|c|c|c|}
\hline Materials & Carbon content (\%) & Oxygen content (\%) & Nitrogen content (\%) \\
\hline A & 69.6 & 22.5 & 7.9 \\
\hline B & 67.6 & 27.5 & 4.9 \\
\hline C & 69.6 & 27.6 & 2.9 \\
\hline
\end{tabular}

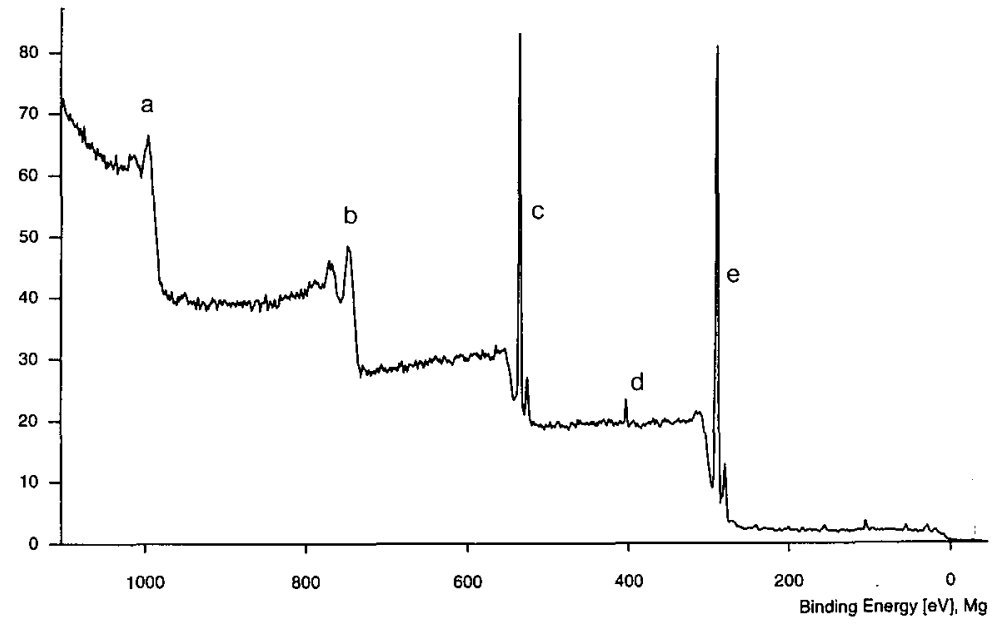

Figure 5.11: XPS spectrum of the surface of material B after incubation in the lysozyme solution for $24 \mathrm{~h}$. (a): carbon Auger; (b): oxygen Auger; (c): oxygen 1s line; (d) nitrogen 1s line; and (e): carbon 1s line.

Figure 5.11 shows the overall XPS spectrum of material B after incubation with lysozyme. The large signals reveal the presence of oxygen and carbon (including the Auger lines). The peak at approximately $400 \mathrm{eV}$ reveals the presence of nitrogen (hence lysozyme). 


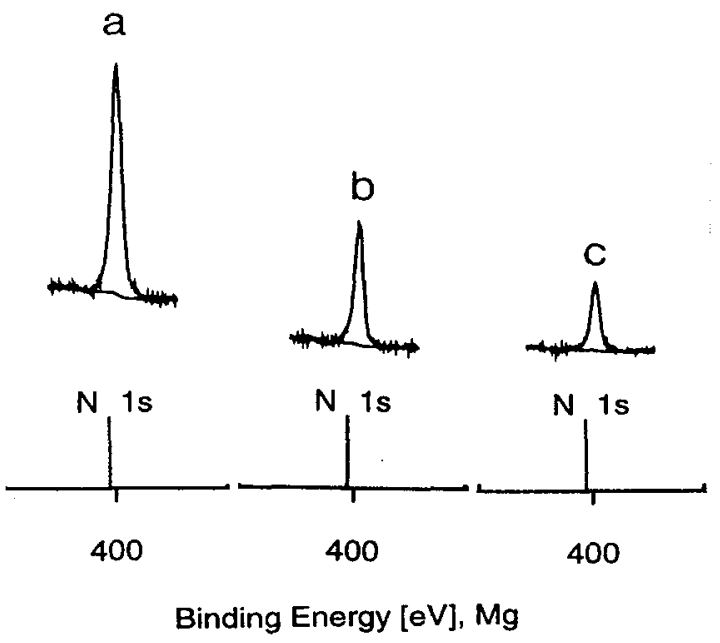

Figure 5.12: Nitrogen 1s lines at $\pm 400 \mathrm{eV}(a-c)$ in the XPS spectra of materials $A-C$, respectively after incubation for $24 \mathrm{~h}$ in the lysozyme solution.

Figure 5.12 shows expansions of the nitrogen lines for materials $\mathrm{A}-\mathrm{C}$. The intensity drops with increasing HEGMA content. This is an expected trend, since more hydrophilic polymeric surfaces have lower affinity for proteins.

\subsection{Concluding remarks}

The present exploration of the properties of HEGMA / BMA copolymers reinforces the idea that these materials are potentially useful for the intended purpose: temporary closure of corneal perforations of medium size. The materials have excellent optical transparency; they are as transparent as the cornea by itself. The detailed physical and (bio)chemical properties can be tuned accurately through synthesis: incorporation of more HEGMA leads to increased hydrophilicity, a lower $\mathrm{Tg}$-value and a lower degree of protein adhesion. Especially remarkable was the finding that cultured human epithelial cells readily grow and proliferate in the presence of the copolymers. At this point two issues require further attention: 
- It is not clear whether the physical/mechanical properties are adequate. While the flexibility of materials B - D appears to be acceptable, it needs to be determined whether these materials are resistant to tearing. This is essential, since the grafts will be held in place by sutures. Another point is that the materials are markedly tough; with initial prototypes of the implant we observed that the suture needles quickly became blunt.

- The adherence of epithelial cells needs to be studied further. Our experiments show growth of epithelium in the presence of the materials, but genuine cellular ingrowth may be imperative in vivo. This would imply, however, that the material must be porous, which would compromise the optical transparency.

Based on these finding a pilot in vivo study, in a rabbit model will be performed in the near future. The results of this pilot study will determine the feasibility of our approach.

\subsection{References}

1 Macsai, M.S.; Agarwal, S.; Gamponia, E. Cornea 1998, 17, 227.

2 Orlin, S.E.; Sulewski, M.E. C. L. A. O. J. 1998, 24, 186.

3 Reisin, I.; Reisin, L.H.; Aviel, E. C. L. A. O. J. 1996, 22, 146.

4 Lekskul, M.; Fracht, H.U.; Cohen, E.J.; Rapuano, C.J.; Laibson, P.R. Cornea 2000, $19,313$.

5 Cheng, C.L.; Tan, D.T.H. Aust. N.Z. J. Ophthalmol. 1999, 27, 437.

6 Hicks, C.; Crawford, G.; Chirila, T.; Wiffen, S.; Vijayasekaran, S.; Lou, X.; Fitton, J.; Maley, M.; Clayton, A.; Dalton, P.; Platten, S.; Ziegelaar, B.; Hong, Y.; Russo, A.; Constable, I. Prog. Retin. Eye Res. 2000, 19, 149.

7 Sangwan, V.S.; Akpek, E.K.; Voo, I.; Zhao, T.Z.; Pinar, V.; Yang, J.; Christen, W.; Baltatzis, S.; Wild, R.; Foster, C.S. Cornea 1999, 18, 707.

8 Nuijts, R.M.M.A.; Kooijman De Groot, M.J.C.; Prins, M.; Pels, E. Arch. Ophthalmol. 1999, 117, 1427.

9 Sharma, A.; Pandey, S.; Sharma, R.; Mohan, K.; Gupta, A. Cornea 1999, 18, 366.

10 Gebhardt, B.M.; Hodkin, M.; Varnell, E.D.; Kaufman, H.E. Cornea 1999, 18, 314.

11 Kompa, S.; Langefeld, S.; Kirchhof, B.; Brenman, K.; Schrage, N. Int. J. Artif. Organs 2000, $23,345$.

12 Sandeman, S.R.; Faragher, R.G.A.; Allen, M.C.A.; Liu, C.; Lloyd, A.W. Br. J. Ophthalmol. 2000, 84, 640. 
13 Adachi, W.; Nishida, K.; Kinoshita, S.; Ishii, Y. Br. J. Ophthalmol. 1998, 82, 1445.

14 Moschos, M.; Droutsas, D.; Boussalis, P.; Tsioulias, G. Doc. Ophthalmol. 1997, 93, 237.

15 Crawford, G.J.; Chirila, T.V.; Vijayasekaran, S.; Dalton, P.D.; Constable, I.J.J. Refract. Surg. 1996, 12,525 .

16 Lou, X.; Vijayasekaran, S.; Chirila, T.V.; Maley, M.A.L.; Hicks, C.R.; Constable, I.J.J. Biomed. Mater. Res. 1999, 47, 404.

17 Tsuk, A.G.; Trinkaus-Randall, V.; Leibowitz, H.M. J. Biomed. Mater. Res. 1997, 34, 299.

18 Ziegelaar, B.W.; Fitton, J.H.; Clayton, A.B.; Platten, S.T.; Maley, M.A. L.; Chirila, T.V. Biomaterials 1999, 20, 1979.

19 Nuijts, R.M.M.A.; Kooijman - de Groot, M.J.C.; Prins, M.; Pels, E. Arch. Ophthalmol. 1999, 117, 1427.

20 Bruining, M.J.; Blaauwgeers, H.G.T.; Kuijer, R.; Jongsma, F.H.M.; Brabander de, J.; Nuijts, R.M.M.A.; Koole, L.H. Bio-Macromolecules 2000, 1, 418.

21 Bruining, M.J.; Blaauwgeers, H.G.T.; Kuijer, R.; Pels, E.; Nuijts, R.M.M.A.; Koole, L.H. Biomaterials 2000, 21, 595 .

22 Bruining, M.J.; Edelbroek-Hoogendoorn, P.S.; Blaauwgeers, H.G.T.; Mooy, C.M.; Hendrikse, F.H.; Koole, L.H. J. Biomed. Mater. Res. 1999, 47, 189.

23 Kingshott, P.; Griesser, H.J. Cur. Opin. Solid State Mat. Sci. 1999, 4, 403.

24 Kingshott, P.; St John, H.A.W.; Griesser, H.J. Anal. Biochem. 1999, 273, 156.

25 Kruft, M.A.B.; Benzina, A.; Bär, F.H.W.M.; van der Veen, F.H.; Bastiaansen, C.W.M.; Blezer, R.; Lindhout, T.; Koole, L H. J. Biomed. Mater. Res. 1994, 28, 1259.

26 Boettner, E.A.; Wolter, J.R. Invest. Ophthalmol. 1962, 1, 776.

27 Nöller, H.G.; Polaschegg, H.D.; Schillalies, H. J. Electron Spectrosc. Relat. Phenom. 1974, 5, 705.

28 Scofield, J.H. J. Electron Spectrosc. Relat. Phenom. 1976, 8, 129.

29 Kruft, M.A.B.; Koole, L.H. Macromolecules 1996, 29, 5513.

30 Beamson, G.; Briggs, D. High resolution XPS of organic polymers. Chichester, U.K., Wiley, 1992. 


\section{Epilogue}

Controlled delivery of drugs to the posterior chamber of the eye poses a significant technical problem. It seems clear that degradable polymeric biomaterials can play an important role in this respect. Previous experiments with well-known biodegradable poly(esters) like poly(glycolic acid) and poly(lactic-co-glycolic acid) have shown, however, that these materials are not really suitable for this purpose. Their degradation is difficult to control and difficult to predict. In most cases, burst degradation will occur, leading to a sudden and largely uncontrolled release of the drug and degradation products.

The research that is described in this thesis was aimed to circumvent the problem of burst degradation, which is a consequence of autocatalysis within the poly(ester) matrix. Key to the new approach was a bifunctional crosslink molecule that consists of two methacrylate head groups, and a linear spacer, which contains two carbonate groups. The carbonates are susceptible to hydrolysis, but the degradation products (two alcohols and $\mathrm{CO}_{2}$ per scission) do not catalyze further degradation of the material. It was verified experimentally that degradation of several newly synthesized prototype materials showed smooth degradation in the course of time. The two families of prototype materials are, however, not suitable for the intended application, one is inhomogeneous, and the other lacks sufficient biocompatibility. The research has indicated that the approach is promising, and further work on the basis of a hydrophilic methacrylate monomer and the crosslink molecule is currently in progress.

In addition, new biomaterials were designed, synthesized, and tested with respect to a problem occurring in corneal surgery. Perforations in the cornea, resulting from injury (e.g., chemical burns), or from pathological thinning, can normally be treated through implantation of donor allograft material. In some cases, however, rejection of the allograft occurs; the risk for this complication is especially high for patients suffering from an auto-immune disease. Then, it is mandatory that the immune system is down-regulated prior to implantation of the donor material. During this period, it is desirable that the perforation be closed by means of a polymeric 
implant. A biocompatible poly(urethane) mesh has been used for this purpose, but this material has the drawback that it is non-transparent. In the course of this thesisresearch, an alternative material was developed; the most suitable candidate was found to be a copolymer of hexaethyleneglycol methacrylate and n-butyl methacrylate. This material features the desirable physical and biological characteristics (it readily supports growth and proliferation of corneal epithelial cells at its surface), except that the sutureability is still insufficient. This aspect is subject of further research.

The research that was conducted during this thesis project demonstrates that new, improved, biomaterials can help to realize further improvements in ophthalmic care and cure. Chapters $2-4$ indicated that alternatives for poly(esters) as carrier materials for the controlled delivery of drugs in the posterior chamber of the eye can be developed. The data presented in Chapter 5 reveals that a taylor-made biomaterial can improve state-of-the-art procedures in the treatment of corneal perforations. While these developments are promising, it is important to keep in mind that extensive further testing and optimalization will be mandatory prior to application of the new biomaterials in clinical practice. 


\section{Summary}

Polymeric biomaterials are widely used in the medical practice. Many of these materials are hydrophilic, i.e., they absorb water upon immersion in an aqueous environment. These hydrogels can be designed and synthesized on the basis of existing techniques; the physical properties can be tailored. The research of this thesis was focused on the development of new improved hydrogels for ophthalmic applications.

Two types of materials are described: (i), biocompatible, degradable polymers that can serve as a matrix in drug release systems. The aim was to achieve controlled drug release in the vitreous body of the eye. (ii), biocompatible and transparent hydrogels for use as a temporary closure of corneal perforations.

The physical and biological properties of hydrogels render these materials suitable for use as a matrix in drug delivery systems. Hydrogels can be made to match living tissue with respect to consistency and water content. Ideally, local release of a toxic drug from a hydrogel matrix only hits the target site; undesirable side-effects can then be circumvented. Degradable matrix materials have the additional advantage that they degrade while the release of the drug proceeds to completion. Hydrogels can also serve to protect vulnerable drugs. Polyesters, like poly(lactic acid) are frequently used as drug release matrix. These materials ultimately fall apart in metabolic monomers, which are easily excreted from the body. The drawback of polyesters is that their breakdown is not always predictable, as a result of auto-catalysis. Consequently, the neighbouring tissue can suddenly be exposed to high concentrations of the drug and degradation products (burst-effect). An excessive inflammatory response is often seen in these cases.

In the course of this research project a new family of degradable polymeric materials was developed and investigated. The materials are three-dimensional hydrogels based on a degradable crosslinking molecule. The crosslinker is a 
dimethacrylate, with two carbonate groups in its molecular structure. The carbonates are susceptible to hydrolysis. When such a three-dimensional network is immersed in an aqueous environment, water uptake and swelling follows. Water molecules penetrate the material from the surface towards the center. The carbonates may react with water resulting in hydrolytic scission. Then, the material starts to fall apart, but no auto-catalysis occurs, since every scission produces two alcohols and $\mathrm{CO}_{2}$. The crosslinker can also be modified such that one, or more than two, carbonate functions are present. Increasing the number of carbonate groups per molecule, will accelerate the degradation process.

Two systems were developed on the basis of this principle. One system was prepared from 1-vinyl-2-pyrrolidinone (NVP) and the crosslinker, the other system was prepared from $\mathrm{N}, \mathrm{N}$-dimethylaminoethyl methacrylate (DMAEMA) and the crosslinker. Degradation and swelling of these materials was investigated, as well as the biocompatibility. Degradation proceeded smoothly in all cases, and there was no evidence of a burst-effect. It also turned out that variation of the crosslink density (synthesis) provides a means to control the rate of swelling and degradation. These effects were seen clearly with the DMAEMA-based materials. These are homogeneous since DMAEMA and the methacrylate groups of the crosslinker have approximately the same reactivity. The NVP-based counterpart materials, however, are not homogeneous, since NVP is much less reactive. The latter materials contain separate domains of high and low crosslink density, and therefore show complex degradation behavior. NMR microimaging revealed that the NVP-derived materials do not show burst degradation and that the degradation process strongly depends on the overall crosslink density. The materials were also subjected to biocompatibility and cytotoxicity tests. The DMAEMA-derived materials turned out to be very cytotoxic. Hence, a new reactive monomer, that can replace both NVP and DMAEMA had to be selected. The well-known monomer 2hydroxyethyl methacrylate featured insufficient hydrophilicity, but promising preliminary results were obtained with hexaethyleneglycol methacrylate (HEGMA). 
Another research line was focused on a new biomaterial for use during the treatment of corneal perforations. These can occur for a pathological reason, or as a result of an accident. The normal treatment is based on implantation of a corneal donor allograft. In some cases, however, the allograft is rejected. This failure is relatively common for patients suffering from an auto-immune disease. These patients can benefit from the implantation of a temporary polymeric implant during down-regulation of the immune-system. The implant should meet a number of stringent requirements, e.g., hydrophilicity, flexibility, optical transparency, sutureabilty. It was found that copolymers of HEGMA and $n$-butyl methacrylate meet most of these requirements. A HEGMA content of $20 \mathrm{~mol} \%$ turned out to be optimal. The sutureability of the material, however, must be improved before the first in vivo tests of this concept can be performed. 



\section{Samenvatting}

Polymere materialen worden in toenemende mate toegepast in de klinische zorg aan patiënten. Vaak zijn deze materialen hydrofiel, d.w.z. ze kunnen in geringe of sterke mate water absorberen. Zogenoemde hydrogelen kunnen met bestaande technieken ontworpen en gesynthetiseerd worden, zodat de juiste materiaal eigenschappen voor een specifiek doel verkregen worden. Bij het in dit proefschrift beschreven onderzoek lag het accent op het ontwikkelen van nieuwe, verbeterde hydrogelen, voor toepassingen in de oogheelkunde.

Twee typen materialen worden beschreven. Enerzijds werd onderzoek naar de ontwikkeling van biocompatibele degradeerbare polymeren gedaan die kunnen dienen als matrix in medicijn afgifte systemen. Het ging hierbij om gecontroleerde afgifte van medicijnen in de achterste oogkamer (glasvocht). Anderzijds is er onderzoek gedaan naar de ontwikkeling van biocompatibele en optisch transparante hydrogelen die gebruikt kunnen worden als tijdelijk cornea implantaat, in patiënten met cornea perforaties.

Hydrogelen zijn door hun fysische en biologische eigenschappen geschikt om te dienen als matrix in medicijn afgifte systemen. Hydrogelen kunnen levend weefsel qua consistentie en watergehalte imiteren. Deze systemen kunnen de lokale afgifte van vaak toxische geneesmiddelen bewerkstelligen; zodoende wordt alleen de "target" plek in het lichaam beïnvloed. De kans op ongewenste (systemische) bijwerkingen van de actieve stof wordt op deze manier geminimaliseerd. Degradeerbare matrices hebben als extra voordeel dat ze niet verwijderd hoeven te worden wanneer de afgifte van het geneesmiddel compleet en het reservoir uitgeput is. Hydrogelen bieden ook bescherming aan de vaak kwetsbare actieve stoffen. Tegenwoordig worden polyesters als poly(melkzuur) vaak gebruikt als matrix in medicijn afgifte systemen. Deze materialen hebben als voordeel dat ze uiteenvallen in lichaamseigen stoffen en dus ook makkelijk verwijderd worden uit het lichaam. Het nadeel van deze poly(esters) is dat de degradatie kinetiek vaak 
grillig en onvoorspelbaar is, omdat het zogenaamde burst-effect optreedt t.g.v. autokatalyse. Dit heeft tot gevolg dat het omringende weefsel plots wordt blootgesteld aan hoge concentraties van geneesmiddel en degradatie producten. Het burst-effect gaat vaak gepaard met een excessieve ontstekings reactie.

In het kader van dit promotie-onderzoek is een geheel nieuwe klasse van degradeerbare polymere hydrofiele materialen ontwikkeld en onderzocht. Het onderzoek betreft hydrogelen die vernet zijn met behulp van een bifunctionele degradeerbare crosslinker. De crosslinker is een dimethacrylaat en bevat twee carbonaatgroepen in zijn structuur. De carbonaateenheden zijn gevoelig voor hydrolyse. Wanneer zo'n drie-dimensionaal netwerk in een waterige omgeving wordt gebracht, dan zal er water uit de omgeving opgenomen worden en zal het systeem zwellen. Het proces van water opname geschiedt vanuit het oppervlak naar het centrum van het materiaal. Zodoende worden de carbonaten aan het oppervlak en in de bulk van het materiaal in contact gebracht met water en zal er hydrolyse, degradatie, optreden. Het materiaal valt daarbij uiteindelijk uiteen in wateroplosbare alcoholen en koolzuurgas, en er treedt geen autokatalyse op. Verder kan de crosslinker ook zodanig gesynthetiseerd worden dat er een of meerdere carbonaat eenheden aanwezig zijn. In het geval dat er per crosslink molekuul meerdere carbonaten aanwezig zijn zal de snelheid van zwellen en degraderen toenemen.

Er zijn twee systemen ontwikkeld gebaseerd op het bovenstaande principe. Het ene systeem bestaat uit 1-vinyl-2-pyrrolidinone (NVP) en de crosslinker en het andere systeem bestaat uit $N, N$-dimethylaminoethyl methacrylaat (DMAEMA) en de crosslinker. Het degradatie- en zwelgedrag van deze materialen is bestudeerd. Er is ook onderzoek gedaan naar de biocompatibiliteit van deze materialen. Inderdaad bleek dat er geen burst degradatie plaatsvindt, en dat ontleding op een gecontroleerde manier geschiedt. Voorts bleek, volgens de verwachting, dat de dichtheid van de crosslinks controle mogelijk maakt over de snelheid van zwelling en degradatie van het materiaal. Hoge concentraties aan de crosslinker hebben tot 
gevolg dat de materialen relatief langzaam zwellen en dus ook langzaam afbreken. Deze eigenschappen worden het duidelijkst waargenomen bij de materialen die gebaseerd zijn op DMAEMA. Dit komt doordat DMAEMA een even grote reactiviteit heeft als de crosslinker. De reaktiviteit van NVP is veel kleiner. Dit heeft tot gevolg dat de op DMAEMA gebaseerd materialen van het type Bernouillian copolymeren (homogene structuur) zijn, terwijl de van NVP afgeleide materialen sterk vernette domeinen en minder sterk vernette domeinen bezitten (niet homogene structuur). De op NVP gebaseerde materialen zullen hierdoor een minder gecontroleerd patroon van degradatie vertonen vergeleken bij de DMAEMA materialen. NMR microimaging studies hebben ook uitgewezen dat de op NVP gebaseerde materialen geen burst-effect vertonen en dat het degradatie patroon sterk afhankelijk is van de hoeveelheid crosslinker. De biocompatibiliteit van de materialen werd ook getest. De DMAEMA materialen bleken zeer toxisch te zijn in vergelijking met de op NVP gebaseerde materialen.

Uit de genoemde experimenten is nieuw inzicht verkregen over de nieuwe degradeerbare materialen. Tevens is duidelijk geworden dat zowel de op NVP als de op DMAEMA gebaseerde materialen ongeschikt zijn voor toepassing bij gecontroleerde geneesmiddel-afgifte. Hieruit volgt, dat een hydrofiel monomeer van de methacrylaat-familie gezocht moest worden om het gestelde doel te bereiken. Het bekende monomeer 2-hydroxyethyl methacrylaat (HEMA) bleek te weinig hydrofiel. Op grond van dit gegeven werd gekozen voor hexaethyleenglycol methacrylaat (HEGMA).

Het onderzoek werd, behalve op degradeerbare systemen voor intra-oculaire geneesmiddel afgifte, ook gericht op nieuwe biomaterialen voor toepassing bij het behandelen van cornea perforaties. Cornea perforaties ontstaan door een pathologische oorzaak, of t.g.v. een ongeval, worden doorgaans behandeld met cornea donor-materiaal. Patienten die lijden aan auto-immuun ziekten stoten het donor materiaal af. Het immuun systeem van deze patienten moet onderdrukt worden alvorens het donor materiaal wordt geimplanteerd. Ter overbrugging van 
deze periode kan het best een polymeer implantaat worden gebruikt. Zo'n implantaat moet aan vele eisen voldoen (hydrofiliciteit, flexibiliteit, optische transparantie, biocompatibiliteit, hechtbaarheid). Gebleken is dat copolymeren van HEGMA en $n$-butyl methacrylaat (BMA) aan de meeste van deze eisen voldoen. Een concentratie van $20 \mathrm{~mol} \%$ HEGMA, bleek geschikte eigenschappen op te leveren voor het gebruik als cornea implantaat. De hechtbaarheid van het materiaal dient evenwel nog verder verbeterd te worden voordat begonnen kan worden met de eerste in vivo-tests van dit nieuwe concept. 


\section{Curriculum Vitae}

Monique Bruining werd geboren op 7 September 1970 te Rotterdam. Na het doorlopen van het VWO aan de Algemene Middelbare School (AMS) te Paramaribo-Suriname, studeerde zij gedurende 1 jaar (1989 - 1990) Bouwkunde aan de Universiteit van de Nederlandse Antillen (UNA). In 1990 starte zij met de studie Chemische Technologie aan de Technische Universiteit Eindhoven. Het afsluitend examen werd in 1996 met goed gevolg afgelegd, middels een afstudeerstage bij de vakgroep Organische Chemie (prof. dr. E. W. Meijer). In de periode 1997 tot 2001 was zij als onderzoeker in opleiding in dienst van de Universiteit Maastricht. Onder leiding van prof. dr. ir. L. H. Koole werkte zij aan haar promotieonderzoek (biomaterialen in de oogheelkunde), waarvan de belangrijkste resultaten staan beschreven in dit proefschrift.

Monique Bruining was born in Rotterdam on September $7^{\text {th }}, 1970$. After finishing secondary school in 1989 (Algemene Middelbare School) in Paramaribo-Suriname, she studied Building and Construction Techniques for one year $(1989-1990)$ at the University of the Netherland Antilles (UNA). In 1990 she started the study Chemical Engineering at the Technical University of Eindhoven. In 1996 she obtained her Master Degree (ir.) under supervision of prof. dr. E. W. Meijer. In 1997 she enrolled in a Ph.D. project (biomaterials in ophthalmology) under supervision of prof. dr. ir. L. H. Koole at the University of Maastricht. The most important findings of this work are described in this thesis. 



\section{List of publications}

Groenendaal, L.; Bruining, M.J.; Vekemans, J.A.J.M.; Havinga, E.E.; Meijer, E.W. " Synthesis and (nonlinear) optical properties of a series of $\mathrm{N}-t-\mathrm{BOC}$ protected D- $\pi-\mathrm{A}$ oligopyrroles", Chemistry of Materials 1998, 10, 226.

Bosman, W.; Bruining, M.J.; Kooijman, H.; Spek, A.L.; Janssen, R.A.J.; Meijer, E.W. " Concerning the localization of end groups in dendrimers", Journal of the American Chemical Society 1998, 120, 8547.

Bruining, M.J;; Edelbroek-Hoogendoorn, P.S.; Blaauwgeers, H.G.T.; Mooy, C.M.; Hendrikse, F.H.; Koole, L.H. " New biodegradable networks of poly(Nvinylpyrrolidinone) designed for controlled non-burst degradation in vitreous body", Journal of Biomedical Materials Research 1999, 47, 189.

Bruining, M.J.; Blaauwgeers, H.G.T.; Kuijer, R.; Pels, E.; Nuijts, R.M.M.A.; Koole, L.H. " Biodegradable three dimensional networks of poly(dimethylaminoethyl methacrylate). Synthesis, characterization and in vitro studies of structural degradation and cytotoxicity", Biomaterials 2000, 21, 595.

Bruining, M.J.; Blaauwgeers, H.G.T.; Kuijer, R.; Jongsma, F.H.M.; de Brabander, J.; Nuijts, R.M.M.A.; Koole, L.H. " Tailoring of new polymeric biomaterials for the repair of medium-sized corneal perforations", Bio-Macromolecules 2000, 1, 418.

Bruining, M.J.; Pijpers, A.P.; Kingshott, P.; Koole, L.H." Studies on new polymeric biomaterials with tunable hydrophilicity, and their possible utility in corneal repair surgery", Biomaterials 2001, submitted.

Bruining, M.J.; Aldenhoff, Y.B.J.; Koole, L.H. " Magnetic resonance microimaging, a versatile tool for studying swelling and degradation behavior of biocompatible hydrogels", Bio-Macromolecules 2001, submitted. 



\section{Dankwoord}

Samen met veel enthousiaste mensen heb ik de afgelopen vier jaar, het werk beschreven in dit proefschrift tot stand gebracht. Het is mij daarom ook een groot genoegen om deze personen te bedanken voor hun inzet.

Allereerst wil ik mijn $1^{\text {ste }}$ promotor, prof. ir. Leo Koole bedanken. Leo, onze samenwerking heb ik als uitermate plezierig ervaren. De pittige discussies, je heldere kijk op het onderzoek en je interesse in mijn werk waren voor mij een enorme stimulans. Jammer, dat ik de leuke uitjes met jullie naar het buitenland in het vervolg zal missen.

Prof. F. Hendrikse, $2^{\text {de }}$ promotor, zou ik graag willen bedanken voor zijn bijdrage aan het onderzoek. Na elke discussie ontstonden er weer onderzoeks ideeën, die we helaas niet allemaal hebben kunnen aangrijpen.

Harriet, samen met jou heb ik bergen werk kunnen verzetten. Je inzicht in het onderzoek, je enthousiasme, je doorzettingsvermogen en niet te vergeten je prettige kijk op het leven zal ik niet gauw vergeten. Ik wens je het allerbeste.

Petra, samen hebben we heel veel lol gehad tijdens het uitvoeren van onze experimenten bij het C.P.V. Ik hoop dat we in de toekomst contact blijven houden. Yvette, Wendy, Roel, Don, Edwin, Camiel, Mireille en Trudy, medewerkers van Maastricht Centre for Biomaterials Research, Ger dach dat ich der niks vaan kós, mèr daor kump her daan: de ontspanne sfeer op hèt lab en ut leuke klasjenere oonder de pauses hèbbe der veur gezörg dat mien AIO periode une plezeerigen tied waor. Öngeluefeluk datgene wat veer us hebbe touwvertrowd. Yvette, ik sta versteld van je magische invloed op ongewillige apparatuur. Trees, het was gewoonweg een lust om naar je verhalen over Indonesië te luisteren. Eric, jammer hè we hebben nog steeds geen biodegradeerbare stent. Ik zal jullie allemaal missen, but we will keep in touch.

Frederik en Myrna, bedankt voor het waardevolle werk dat jullie hebben verricht. Chris, Marije en Frank, ik ben jullie erg dankbaar voor het klaren van de vaak moeilijke klussen waar ik jullie voor spande. Ik stond altijd versteld van jullie inzicht en inzet om het project tot een goed einde te brengen. 
De audio-visuele dienst, bedankt voor jullie snelle service bij het bewerken van documenten.

May, Peter en Joyce, bedankt voor jullie begeleiding tijdens de vele experimenten in jullie operatie ruimten.

Paul Pijpers, jouw eindeloos geduld en wetenschappelijk inzicht hebben gezorgd voor prachtige XPS resultaten.

Roel Kuijer, Judith Vincent, Anita Levels, Frans Jongsma, John de Brabander, Peter Kingshot, Wiep Kingma, Hans Wilderbeek, Michael de Graaf en Wilfred van der Pelt, bedankt voor jullie hulp bij de verscheidene metingen.

Frans, Maaike en Karin, ik hoop dat we onze dinner-dates blijven voortzetten.

Paul en Dave, de rit Eindhoven - Maastricht leek altijd heel erg kort wanneer we carpoolden.

Cristina en Paul, Camiel en Inga, Rick en Romana, bedankt voor alle gezellige momenten en ook voor het infecteren van Marwijn en ik, met het baby-boom virus.

Petra, Frans, Boukje, Ward en Oma bedankt, jullie staan altijd met raad en daad klaar om te helpen.

Claire en Franklin, wat kunnen we samen toch heerlijk aan de werkelijkheid ontsnappen en ons wanen in tropische oorden. Ik hoop dat we ons binnenkort echt in zo'n omgeving bevinden.

Tante An en oom Loet, tante Helen en oom Johan, bedankt voor alle goede zorgen in de afgelopen jaren.

Oma Meeta, ik heb heel veel steun gehad aan jouw liefdevolle woorden en je nuchtere kijk op vele zaken. Oma, je bent geweldig.

$\mathrm{Ma}, \mathrm{Pa}$, Danielle, Lisette, Vernon, Mark, Abigail en Diego ondanks dat jullie meestal aan de andere kant van de oceaan zitten, heb ik altijd jullie liefde en steun dagelijk ervaren. You are all always a heartbeat away.

Marwijn, mijn maatje, je hebt ervoor gezorgd dat ik mijn hoofd altijd koel kon houden in deze drukke periode. We staan nu op de drempel van een nieuwe fase in ons leven. Samen met onze eerste spruit maken we er een groot feest van!!!!!!! 